UNIVERSIDADE FEDERAL DO RIO GRANDE DO SUL

Escola de Engenharia

Programa de Pós-Graduação em Engenharia de Minas, Metalúrgica e de Materiais PPGE3M

KELLEN TEBALDI DA CUNHA

AVALIAÇÃO DA QUALIDADE DO REVESTIMENTO EM TUBOS DE AÇO GALVANIZADO

Porto Alegre, 31 de maio de 2021. 
KELLEN TEBALDI DA CUNHA

\section{AVALIAÇÃO DA QUALIDADE DO REVESTIMENTO EM TUBOS DE AÇO GALVANIZADO}

Dissertação submetida ao Programa de PósGraduação em Engenharia de Minas, Metalúrgica e de Materiais - PPGE3M da Universidade Federal do Rio Grande do Sul, como requisito à obtenção do título de Mestre em Engenharia.

Área de Concentração: Ciência e Tecnologia dos Materiais

Orientador: Prof. Dr. Hugo Marcelo Veit

Porto Alegre, 31 de maio de 2021. 


\section{AVALIAÇÃO DA QUALIDADE DO REVESTIMENTO EM TUBOS DE AÇO GALVANIZADO}

Esta Dissertação foi analisada e julgada adequada para a obtenção do título de Mestre em Engenharia e aprovada em sua forma final pelo Orientador e pela Banca Examinadora designada pelo Programa de Pós-Graduação em Engenharia de Minas, Metalúrgica e de Materiais - PPGE3M da Universidade Federal do Rio Grande do Sul.

Prof. Dr. Hugo Marcelo Veit

Aprovada em:

\section{BANCA EXAMINADORA}

Prof. Dra. Angela Cristina Kasper - UFRGS

Prof. Dr. Alvaro Meneguzzi - PPGE3M/UFRGS

Prof. Dr. Rodrigo Sanchotene Silva - UERGS 


\section{AGRADECIMENTOS}

Agradeço primeiramente à Deus pela saúde e por me permitir realizar esse sonho.

Ao professor Dr. Hugo Marcelo Veit por acreditar em mim e me orientar na condução desta pesquisa.

Ao técnico Wilbur por todo apoio e amizade e também à toda equipe do Laboratório de Corrosão, Proteção e Reciclagem de Materiais (LACOR - UFRGS) pelo apoio na realização das análises.

À empresa Soluções Usiminas pela oportunidade, incentivo à pesquisa e acesso aos processos de galvanização. Agradeço também à todas as amizades que conquistei no período em que estive como parte da equipe da Soluções Usiminas, foram essenciais no meu crescimento pessoal e profissional e com certeza, amizades que levo para a vida e no meu coração.

À minha família, em especial para meu noivo Lucas Dahmer e minha mãe, Ivalmira Tebaldi pelo amor, paciência e compreensão nos momentos difíceis.

Aos amigos que acompanharam essa trajetória, apoiaram e entenderam os diversos "nãos" para os convites do final de semana. 
AGRADECIMENTOS

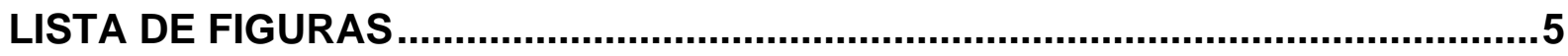

LISTA DE TABELAS

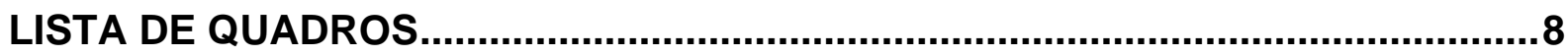

LISTA DE GRÁFICOS

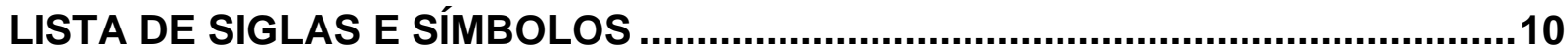

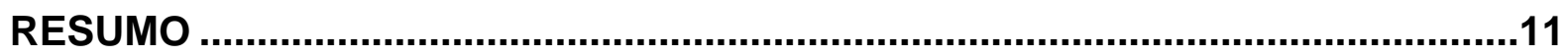

ABSTRACT

1. INTRODUÇÃO

2. OBJETIVOS

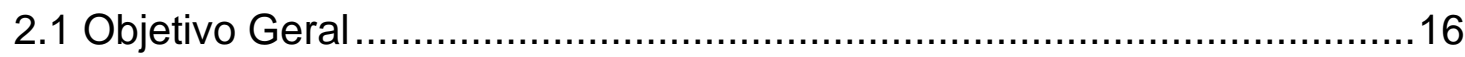

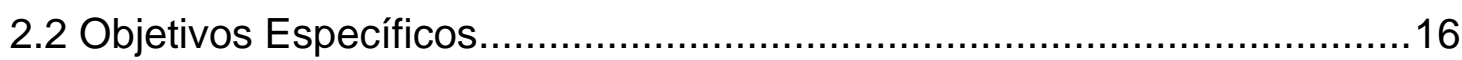

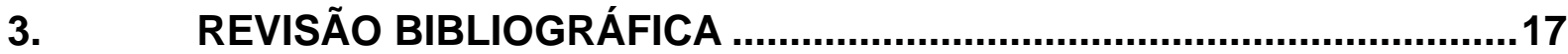

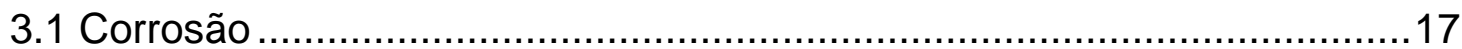

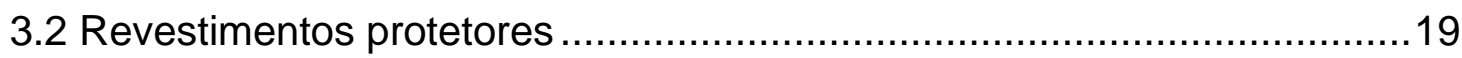

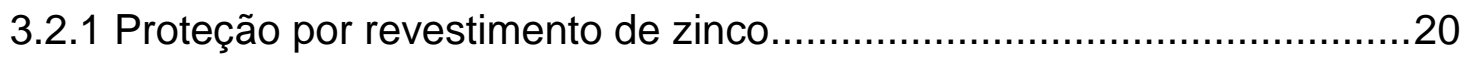

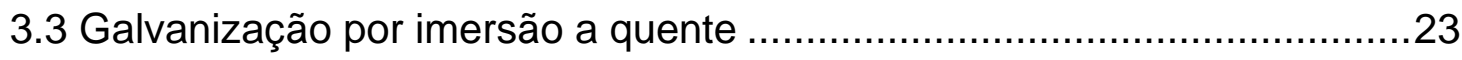

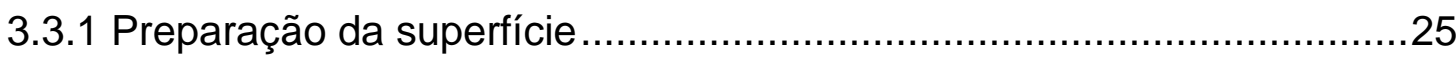

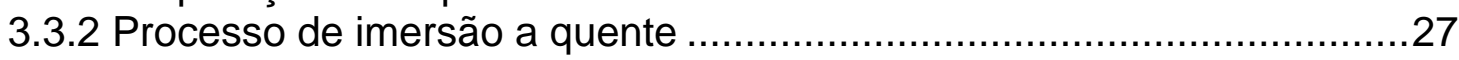

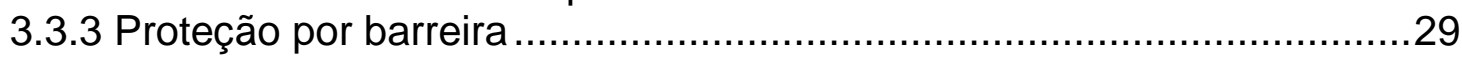

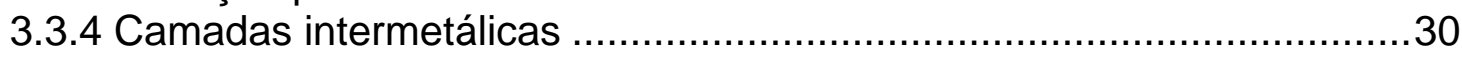

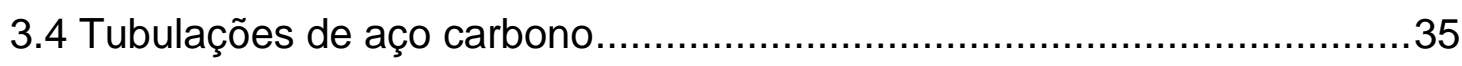

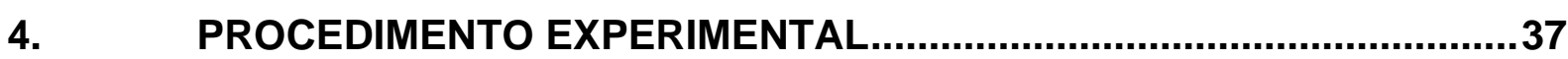

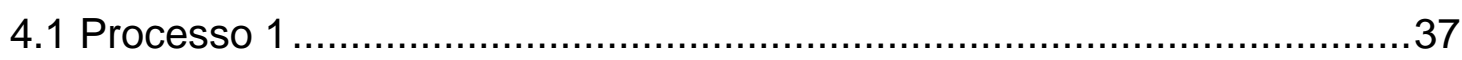

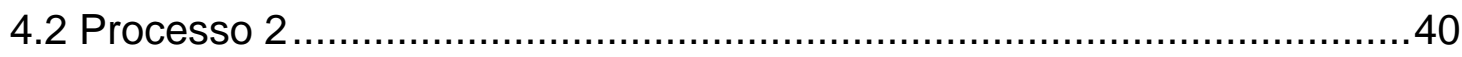

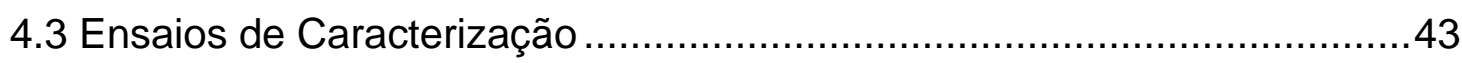

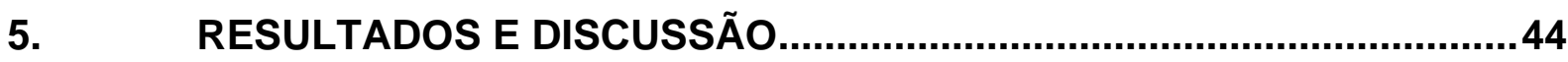

5.1 Ensaios de Espessura de Camada, Uniformidade e Achatamento ..........44

5.2 Análise Metalográfica para verificação das fases intermetálicas ...............48

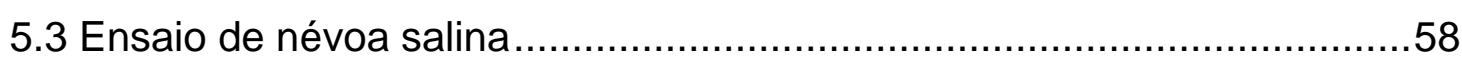

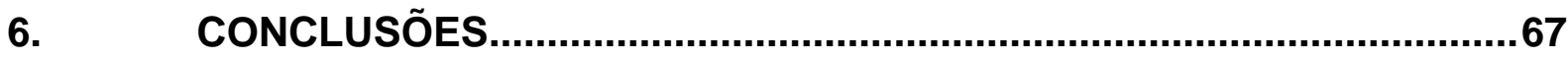

7. SUGESTÕES PARA TRABALHOS FUTUROS ....................................69

8. REFERÊNCIAS BIBLIOGRÁFICAS ............................................70 


\section{LISTA DE FIGURAS}

Figura 1 -Representação esquemática da proteção catódica do zinco ao aço. ........21

Figura 2 - Efeito do $\mathrm{pH}$ na corrosão do revestimento de zinco ..............................22

Figura 3 - Esquema do processo de galvanização..............................................27

Figura 4 - Esquema de formação da proteção por barreira .........................................30

Figura 5 - Diagrama de fases Fe-Zn de Kubaschewski.........................................31

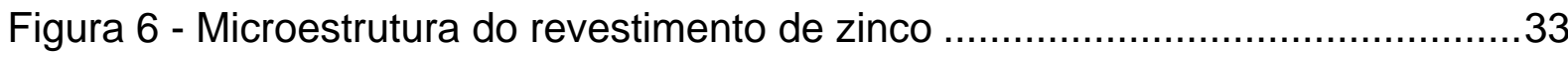

Figura 7 - Representação esquemática da formação das camadas de fase Fe-Zn ..34

Figura 8 - Tubos de aço carbono, em seção circular, com costura, pretos ................36

Figura 9 - Tubos de aço carbono, em seção circular, com costura, galvanizados ....36

Figura 10 - Fluxograma do processo de galvanização de tubos no processo 1 ........38

Figura 11 - Ilustração do processo de galvanização no processo 1 ..........................39

Figura 12 - Fluxograma do processo de galvanização de tubos no processo 2........40

Figura 13 - llustração do processo automatizado de galvanização de tubos no

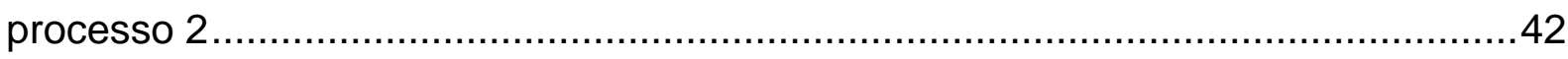

Figura 14 - Imagens obtidas no ensaio de metalografia.....................................49

Figura 15 - Imagem da amostra $1 \mathrm{~A}$, diâmetro $21,30 \mathrm{~mm}$ referente ao Processo $1 \ldots 51$

Figura 16 - Imagem da amostra 1A, diâmetro $21,30 \mathrm{~mm}$ referente ao Processo 2 ...52

Figura 17 - Imagem da amostra 2B, diâmetro $60,30 \mathrm{~mm}$ referente ao Processo 1 ...53

Figura 18 - Imagem da mostra 2A, diâmetro 60,30 mm referente ao Processo 2 .....54

Figura 19 - Imagem da amostra 3A, diâmetro $76,10 \mathrm{~mm}$ referente ao Processo 1 ...55

Figura 20 - Imagem da amostra 3C, diâmetro 76,10mm referente ao Processo 2 ...56

Figura 21 - 24 horas de ensaio em corpos de prova diâmetro 21,30mm - processo 1

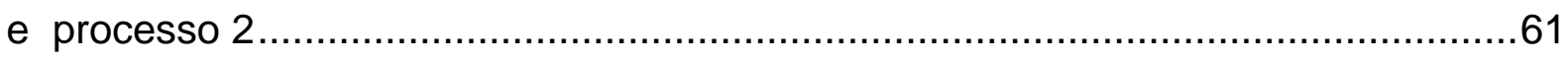

Figura 22 - 24 horas de ensaio em corpos de prova diâmetro 60,30mm - processo 1

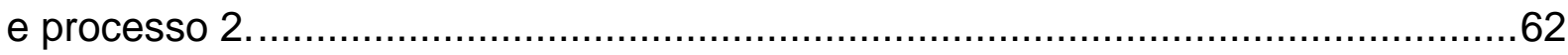

Figura 23 - 24 horas de ensaio em corpos de prova diâmetro 76,10mm - processo 1 e processo 2

Figura 24 - 336 horas de ensaio em corpos de prova diâmetro 21,30mm - processo 1 e processo 2 .63 
Figura 25 - 336 horas de ensaio em corpos de prova diâmetro 60,30mm - processo 1

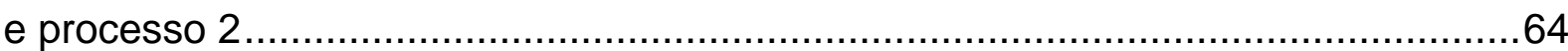

Figura 26 - 336 horas de ensaio em corpos de prova diâmetro 76,10mm - processo 1

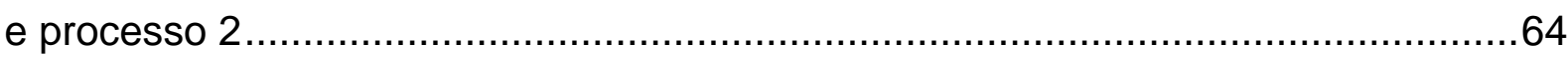

Figura 27 - 1392 horas de ensaio em corpos de prova diâmetro 21,30mm - processo 1 e processo 2 65

Figura 28 - 1392 horas de ensaio em corpos de prova diâmetro 60,30mm - processo 1 e processo 2 .66 Figura 29 - 1392 horas de ensaio em corpos de prova diâmetro 76,10mm - processo 1 e processo 2 


\section{LISTA DE TABELAS}

Tabela 1 - Composição química nominal do aço ............................................

Tabela 2 - Composição (\%) de zinco e alumínio no banho de zinco. ..............43

Tabela 3 - Nomenclatura dos corpos de prova ............................................4

Tabela 4 - Ensaios realizados com amostras do processo 1 ..........................45

Tabela 5 - Ensaios realizados com amostras do processo 2.........................45

Tabela 6 - Corpos de prova submetidos ao ensaio de MEV/EDS. .................48 


\section{LISTA DE QUADROS}

Quadro 1 - Composição de Fe e Zn nas fases intermetálicas do revestimento

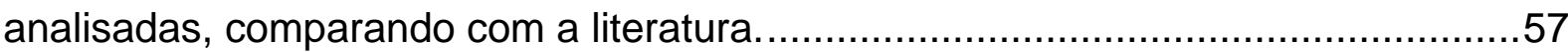

Quadro 2 - Relatório de acompanhamento da evolução da corrosão nos corpos de prova submetidos ao ensaio de névoa salina. .59 


\section{LISTA DE GRÁFICOS}

Gráfico 1 - Estimativa do tempo de vida útil de materiais galvanizados.

Gráfico 2 - Espessura do revestimento das amostras comparando com o mínimo estabelecido pela NBR5580

Gráficos 3, 4, 5 e 6 - Análise de EDS da composição em massa (\%) de Fe e Zn nas fases intermetálicas, amostra $1 \mathrm{~A}$ P1

Gráficos 7, 8, 9 e 10 - Análise de EDS da Composição em massa (\%) de Fe e Zn nas fases intermetálicas, amostra $1 \mathrm{~A}$ P2.

Gráficos 11, 12, 13 e 14 - Análise de EDS da Composição em massa (\%) de Fe e Zn nas fases intermetálicas, amostra 2B P1 .53

Gráficos 15, 16, 17 e 18 - Análise de EDS da composição em massa (\%) de Fe e Zn nas fases intermetálicas, amostra 2A P2 .54

Gráficos 19, 20, 21 e 22 - Análise de EDS da composição em massa (\%) de Fe e Zn nas fases intermetálicas, amostra 3A P1. 55

Gráficos 23, 24, 25 e 26 - Análise de EDS da composição em massa (\%) de Fe e Zn nas fases intermetálicas, amostra 3C P2. .56

Gráfico 27 - Evolução da corrosão vermelha nos corpos de prova de 336 horas a 1392 horas de ensaio. 60 


\section{LISTA DE SIGLAS E SÍMBOLOS}

MEV - Microscópio eletrônico de varredura

EDS - Espectroscopia por Energia Dispersiva

NBR - Norma Brasileira

PIB - Produto Interno Bruto

IZA - International Zinc Association

USP - Universidade de São Paulo

$\mathrm{pH}$ - Potencial de hidrogênio

$\Gamma-$ Gama

$\delta$ - Delta

$\zeta$ - Zeta

$\eta$ - Eta

HCP - Estrutura hexagonal compacta

CCC - Estrutura cubica de corpo centrado

ERW - Soldagem em resistência elétrica de alta frequência

${ }^{\circ} \mathrm{Be}$ - Graus Baumé

SHG - Special High Grade 


\section{RESUMO}

Tendo em vista que todos os materiais interagem com o meio em que estão expostos, nos metais, o processo de corrosão é considerado um processo natural, porém, indesejado. Nos aços carbono esse processo pode ser bem acelerado, o que suscita o desenvolvimento de revestimentos protetores a fim de controlar e minimizar os efeitos da corrosão. Dentre os processos de aplicação de revestimentos metálicos para proteção do aço, o processo comumente utilizado é a galvanização por imersão a quente, que consiste na aplicação de zinco metálico na superfície do aço carbono. Neste trabalho o objetivo foi avaliar a qualidade do revestimento de zinco em tubos galvanizados por imersão a quente produzidos por uma empresa metal-mecânica, comparando o processo antigo de produção, com baixo grau de controle e automação com o processo automatizado e com melhores controle operacionais. A investigação ocorreu através de testes realizados em amostras retiradas do processo antes e após a modificação com intuito de comparar os resultados e evidenciar as melhorias obtidas. Foram utilizados corpos de prova de tubos de ambos processos nos diâmetros: $21,30 \mathrm{~mm}, 60,30 \mathrm{~mm}$ e 76,10mm. Os ensaios utilizados foram: medição da espessura do revestimento, verificação da massa do revestimento protetor de zinco, uniformidade do revestimento, achatamento, análise metalográfica e Microscopia Eletrônica de Varredura (MEV) acoplado a Espectroscopia por energia dispersiva de Raio X (EDS) e ensaio de corrosão acelerada em câmara de névoa salina. Os resultados dos ensaios de espessura do revestimento demonstraram que, nos corpos de prova de tubos $21,30 \mathrm{~mm}$ houve uma redução de até $15 \%$ na espessura de revestimento e $21 \%$ de massa de revestimento.

Com a observação das fases intermetálicas foi possível observar a morfologia das camadas de fase. Os ensaios de névoa salina demonstraram que ambos os processos tiveram uma duração de 1392 horas em câmara de névoa salina até atingir o grau máximo de corrosão vermelha, resultado que pode ser considerado positivo, evidenciando que, mesmo com a redução da espessura do revestimento para mais próximo do mínimo estabelecido pela ABNT NBR 5580:2015 a qualidade do revestimento e a proteção foram mantidas.

Palavras-chave: Galvanização; Revestimento; Zinco; Tubos. 


\begin{abstract}
All material have some kind of interaction with the environment in which they are exposed. In metals, the corrosion process is considered a natural process, however, an undesired one. In carbon steels, this process can be very fast, encouraging the development of protective coatings. The most commonly used process is hot dip galvanizing (consisting on the application of metallic zinc on the surface of carbon steel). In this dissertation, the objective was to evaluate the quality of zinc coating in hot dip galvanized conduction pipes, produced by a metal-mechanic company, comparing the old production process, with low degree of control and automation, with the automated process and with better operational controls. The investigation was performed through tests on samples taken from the process before and after the improvement in order to compare the results and evidence the improvements obtained. Test specimens from pipes of both processes were used in the diameters: $21.30 \mathrm{~mm}, 60.30 \mathrm{~mm}$ and $76.10 \mathrm{~mm}$. The tests used were: measurement of the coating thickness through a non-destructive test, verification of the zinc protective coating mass, uniformity of the coating, flattening, metallographic analysis and Scanning Electron Microscopy (SEM) coupled with Energy Dispersive X-Ray Spectroscopy (EDS) and accelerated corrosion test in a mist chamber saline. The results of the coating thickness tests showed that, in the $21,30 \mathrm{~mm}$ pipe specimens, there was a reduction of up to $15 \%$ in the coating thickness in $\mu \mathrm{m}$ and $21 \% \mathrm{in} \mathrm{g} / \mathrm{m}^{2}$ of coating mass.

Through the observation of the intermetallic phases it was possible to observe the morphology of the phase phases. With the salt spray tests it was demonstrated that both processes had a duration of 1392 hours in salt spray chamber until reaching the maximum degree of red corrosion, a result that can be considered positive, showing that, even with the reduction of the coating thickness to closer to the minimum established by NBR 5580, the quality of the coating and the protection were maintained.
\end{abstract}

Keywords: Galvanizing; Coating; Zinc; Pipes. 


\section{INTRODUÇÃO}

Todos os materiais experimentam algum tipo de interação, em maior ou menor grau, com os ambientes em que são expostos. Tais interações podem comprometer a utilização dos materiais, resultado da deterioração das suas propriedades, sendo que os mecanismos de deterioração ocorrem de maneira diferente em cada tipo de material.

Nos metais, o processo de corrosão normalmente ocorre por processos eletroquímicos, sendo considerado um processo natural, porém, indesejado. Os metais apresentam uma condição termodinâmica instável e tendem a mudar para uma condição estável através da formação de óxidos, hidróxidos, sais, etc. Os ambientes de corrosão incluem atmosfera, solução aquosa, solo, ácidos, bases, solventes inorgânicos, dentre outros. As variáveis dos ambientes de corrosão influenciam diretamente na propriedade de corrosão dos materiais [1, 2].

Os gastos com prevenção ou manutenção e substituição de superfícies corroídas apresentam proporções significativas em termos econômicos. Como medidas para prevenir ou minimizar os efeitos da corrosão podemos citar a seleção do material, a interação do ambiente, uso de inibidores, aplicações de revestimento, proteção catódica e alterações no projeto. Sendo a utilização de revestimentos protetores uma das medidas mais utilizadas para prevenir a corrosão dos materiais. Os principais requisitos de um revestimento são: baixa permeabilidade, resistência química ao meio agressivo, dilatação térmica compatível com o substrato, propriedades físicas adequadas aos abusos que receberá por abrasão, trafego, impacto, flexão, etc.. Também deve ser considerada a viabilidade econômica do processo de aplicação do revestimento $[3,4]$.

Os revestimentos podem ser: metálicos, não-metálicos inorgânicos ou orgânicos, sendo os revestimentos metálicos de proteção catódica ou anódica. As finalidades do uso de revestimentos em superfícies metálicas estão relacionadas a proteção contra corrosão, uso decorativo e/ou aumento da resistência ao desgaste da superfície metálica [1].

Escolhendo o revestimento metálico levando em consideração a resistência à corrosão, podemos dividir em duas categorias: revestimentos metálicos nobres e 
revestimentos metálicos de sacrifício. Como o próprio nome diz, revestimentos metálicos nobres são metais mais nobres (como níquel, prata, cobre, chumbo, cromo) aplicados sobre o metal base, geralmente aço. Neste tipo de revestimento, para garantir a proteção do metal base, é fundamental que o revestimento aplicado seja isento de imperfeições, poros ou trincas, pois a direção da corrente galvânica causará 0 ataque do metal base, podendo levar à completa deterioração do substrato. Em revestimentos metálicos de sacrifício, como o zinco e o cádmio, ocorre o contrário, o grau de perfeição do revestimento não possui grande importância, pois a corrente galvânica á inversa ao que ocorre em metais nobres. Neste tipo de revestimento, enquanto a corrente fluir e o revestimento estiver em contato com o substrato, o metal base estará protegido catodicamente. Quanto mais espesso for o revestimento, maior será a duração da proteção catódica. [5]

Sendo o zinco um metal mais eletronegativo que o ferro, quando o revestimento de zinco sofre descontinuidade, o zinco sofre, preferencialmente, a dissolução eletrolítica, protegendo catodicamente o ferro. O zinco também oferece proteção por barreira, uma vez que os produtos da corrosão do zinco são insolúveis e aderentes, se depositam na superfície protegendo o metal com o contato direto com a atmosfera ou meio eletrolítico, evitando a sua corrosão [3,6]. Dentre os principais tipos de aplicação de revestimento de zinco, estão os processos de imersão a quente e eletrodeposição [7].

Diferentemente da maioria dos revestimentos, a galvanização por imersão a quente produz um revestimento aderente, em que ferro e zinco reagem formando fases intermetálicas com teores de ferro e zinco diferente em cada uma das camadas de fase. O processo de imersão a quente consiste basicamente na imersão de uma peça com a superfície limpa em um banho de zinco fundido. Ao retirar a peça do banho de zinco se faz necessário o resfriamento para cessar o crescimento das camadas de fase intermetálicas do revestimento [7].

Uma das aplicações do aço galvanizado é em tubos para condução de fluidos não corrosivos. Estas tubulações são produzidas em aço carbono e são utilizados para fins industrial, mecânico ou estrutural e podem apresentar características especiais quanto ao seu aspecto superficial, revestimento, seção, formato, diâmetro, comprimento e outros requisitos, conforme a aplicação desejada [8]. 
Nesse contexto, este trabalho analisou o revestimento de zinco em tubos de condução, utilizando como referência a ABNT NBR 5580:2015 [9], referente a tubos de condução galvanizados por imersão a quente e especificação para galvanização por imersão a quente em produtos de ferro fundido e aço carbono, em uma linha de galvanização que passou por modernização, automatizando o processo e os sistemas de controle, e também mudanças na etapa de limpeza da superfície, como troca da solução de decapagem. 


\section{OBJETIVOS}

\subsection{Objetivo Geral}

Avaliar a qualidade do revestimento de zinco de tubos galvanizados por imersão a quente em um processo com baixo controle do tempo de imersão e em um processo com controle automatizado do tempo de imersão, comparando ambos revestimentos.

\subsection{Objetivos Específicos}

- Avaliar a espessura do revestimento de zinco por processo não destrutivo;

- Avaliar a massa do revestimento protetor de zinco;

- Verificar a uniformidade do revestimento, através do Ensaio de Preece;

- Avaliar a propriedade mecânica do revestimento, através do ensaio de achatamento;

- Avaliar as fases intermetálicas do revestimento com o substrato;

- Avaliar o processo de corrosão branca e vermelha, com a exposição do revestimento em ensaio de névoa salina. 


\section{REVISÃo BIBLIOGRÁFICA}

Este capítulo apresentará, inicialmente, uma revisão da bibliografia sobre corrosão. Na sequência haverá uma abordagem sobre revestimentos protetores com ênfase em revestimento protetor de zinco obtido por galvanização por imersão a quente. Em seguida, abordará brevemente sobre tubulações de aço carbono, que será o foco deste trabalho.

\subsection{Corrosão}

A interação dos materiais com o ambiente pode comprometer a utilização dos materiais pela deterioração das suas propriedades, como a corrosão em metais. A corrosão atmosférica é responsável pelas maiores perdas, e a umidade contendo oxigênio dissolvido é o principal agente corrosivo; em atmosferas marinhas, a presença de cloreto de sódio torna estes ambientes extremamente corrosivos. [1,2].

É importante classificar a corrosão conforme a maneira que ela se manifesta. A corrosão metálica pode ser classificada em oito maneiras:

- Corrosão por pite: corrosão localizada que se manifesta como "pontos" ou "buracos" na superfície dos metais. É importante avaliar o número de pites por área, diâmetro e profundidade de pites. Como consequência, pode ocorrer a diminuição da resistência à fadiga e resistência mecânica do material, podendo levar ao rompimento do mesmo, pois favorece a nucleação de trincas [1];

- Corrosão uniforme ou generalizada: é a forma mais comum de corrosão, ocorre em toda a superfície exposta do material. Como exemplos podemos citar a oxidação no aço e no ferro em geral, bem como o escurecimento e perda de brilho em pratarias [2];

- Corrosão em frestas: forma de corrosão localizada, geralmente associada à ambientes restritos pela estagnação de eletrólitos, acontece devido à alterações químicas dentro da fresta. É muito comum em parafusos, porcas, arruelas, materiais de isolação, películas de tinta descoladas, juntas expostas [10]; 
- Corrosão sob tensão: acontece quando um material é submetido a tensões de tração em contato com um meio corrosivo. A consequência deste tipo de corrosão é o surgimento de trincas no material que podem se propagar de maneira lenta até atingirem tamanho e proporção para ruptura do material [10];

- Corrosão galvânica: este tipo de corrosão se manifesta quando duas ou mais ligas metálicas possuem diferentes potenciais eletroquímicos e banhados por um mesmo eletrólito [11];

- Erosão-corrosão: uma ação combinada de ataque químico e abrasão mecânica em consequência da movimentação de um fluido. Pode-se dizer que todas as ligas metálicas são suscetíveis a este tipo de corrosão. É encontrada com frequência em tubulações, principalmente em áreas de dobras, curvas e mudanças bruscas de diâmetro, posição onde o fluido muda de direção ou o escoamento se torna turbulento[2];

- Corrosão intergranular: ocorre ao longo das regiões de contorno de grão para algumas ligas metálicas em ambientes específicos. A ocorrência deste tipo de corrosão prevalece em aços inoxidáveis [2];

- Fragilização por hidrogênio: semelhante à corrosão sob tensão. Algumas ligas metálicas (principalmente aços) têm uma redução significativa na ductilidade e resistência à tração quando o hidrogênio atômico penetra no interior do material. É um tipo de falha observada em ambientes corrosivos como decapagem, eletrogalvanização e atmosferas que contenham hidrogênio (incluindo vapor de água) [2].

Os gastos com prevenção ou manutenção e substituição de superfícies corroídas apresentam proporções significativas em termos econômicos, representando em torno de $5 \%$ do PIB países industrializados. De acordo com um estudo realizado pelo International Zinc Association (IZA) com o apoio da USP, em 2015, identificou que $4 \%$ do PIB do Brasil foi consumido pela corrosão, valor equivalente a mais de 200 bilhões de reais, sendo o litoral o local mais afetado pela corrosão. Como medidas para prevenir ou minimizar os efeitos da corrosão podemos citar a seleção do material, a interação do ambiente, uso de inibidores, aplicações de revestimento, proteção catódica e alterações no projeto [2, 12]. 
Sendo a utilização de revestimentos protetores uma das medidas mais utilizadas para prevenir a corrosão dos materiais, no próximo capítulo será feira uma breve revisão sobre os diferentes tipos, entre eles, a galvanização, que é o foco deste trabalho.

\subsection{Revestimentos protetores}

Sendo a corrosão um processo eletroquímico, provocado por correntes de corrosão que circulam entre duas áreas de uma superfície metálica, ou de duas superfícies metálicas, através de um meio condutor, os mecanismos de proteção irão atuar:

- no material: escolha de materiais que pode ir até a substituição de material metálico por um material não metálico;

- no meio: é possível atuar no meio com ouso de inibidores de corrosão, desumidificação, permutação de íon, etc.;

- na superfície de contato: aplicação de revestimento entre a superfície e o meio, evitando o contato do metal com o ambiente agressivo;

- sobre as correntes de corrosão: a imposição de uma corrente externa, de sentido contrário às correntes de corrosão, constitui o sistema de proteção catódica [3].

Revestimentos não metálicos inorgânicos são formados ou depositados diretamente na superfície metálica. Deste tipo de proteção, os mais utilizados são esmaltes vítreos, porcelanas, cimentos, óxidos, carbetos, nitretos, boretos e silicetos. Revestimentos não metálicos orgânicos (tintas), constituem o método de controle da corrosão mais utilizado, cerca de $90 \%$ das superfícies metálicas são revestidas por tintas. As tintas tem em sua composição resinas, pigmentos e solvente e alguns coadjuvantes como plastificantes, secantes e catalisadores, são aplicadas de forma líquida ou em pó e após o processo de secagem ou cura transformam-se em um filme sólido, fino, aderente, impermeável e flexível. Porém, para garantir a eficiência do sistema de pintura é necessária a preparação da superfície e a avaliação do meio corrosivo a que o material será exposto, bem como do próprio processo de pintura 
adotado, tempo de alternância das aplicações, equipamentos adequados e outros cuidados [4].

Há também os revestimentos compósitos, formados pela união de materiais para formar um revestimento que possa garantir características especiais como maior durabilidade, boa estabilidade dimensional numa alta faixa de temperatura, alta força dielétrica e baixa permeabilidade [4].

Revestimentos metálicos, além de oferecer proteção à corrosão, possuem finalidades decorativas, resistência, função elétrica e de endurecimento superficial. Ao utilizar metais em revestimentos, a ação protetora explica-se pela formação de películas, de óxidos, hidróxidos e outros compostos que reagem com os oxidantes do meio corrosivo. É preciso que a película protetora tenha boa aderência ao material [1].

Os revestimentos metálicos podem ser: catódicos em relação ao material a ser recoberto, porém, o revestimento deve ser perfeitamente isento de falhas, caso contrário, na presença de eletrólitos formará uma pilha galvânica; ou anódicos em relação ao material a ser recoberto. Neste caso, se houver imperfeições no revestimento, na presença de eletrólitos, o metal do revestimento será o ânodo da pilha e protegerá catodicamente o material [1].

Dentre os revestimentos metálicos, para proteger o aço carbono da corrosão, o zinco, é um dos revestimentos mais utilizados. A aplicação do revestimento de zinco pode ser feita por diferentes processos, dentre eles, a galvanização por imersão a quente, foco deste trabalho.

\subsubsection{Proteção por revestimento de zinco}

A utilização de revestimento de zinco tem numerosas e variadas aplicações, sendo amplamente utilizados para proteger o aço contra a corrosão atmosférica, na água, no solo e em outros meios. Tem aplicações na indústria, construção civil, instalações de rede de distribuição de água, transporte de fluidos, equipamentos de refrigeração, indústria naval e automobilística, estruturas metálicas, equipamentos elétricos, entre outros. A maior utilização do revestimento de zinco se dá no aço, devido a sua facilidade de aplicação e elevada resistência à corrosão [3].

Sendo o zinco um metal mais eletronegativo que o ferro, quando o revestimento de zinco sofre descontinuidade e os dois metais estão em contato no mesmo meio 
agressivo, o zinco sofre, preferencialmente, a dissolução eletrolítica, protegendo catodicamente o ferro, conforme apresentado na Figura 1. Pode ocorrer, em certos casos, dos produtos de corrosão do zinco recobrirem o metal base exposto e, se aderentes, formar uma película e promover a sua proteção [2,3].

Figura 1 -Representação esquemática da proteção catódica do zinco ao aço.

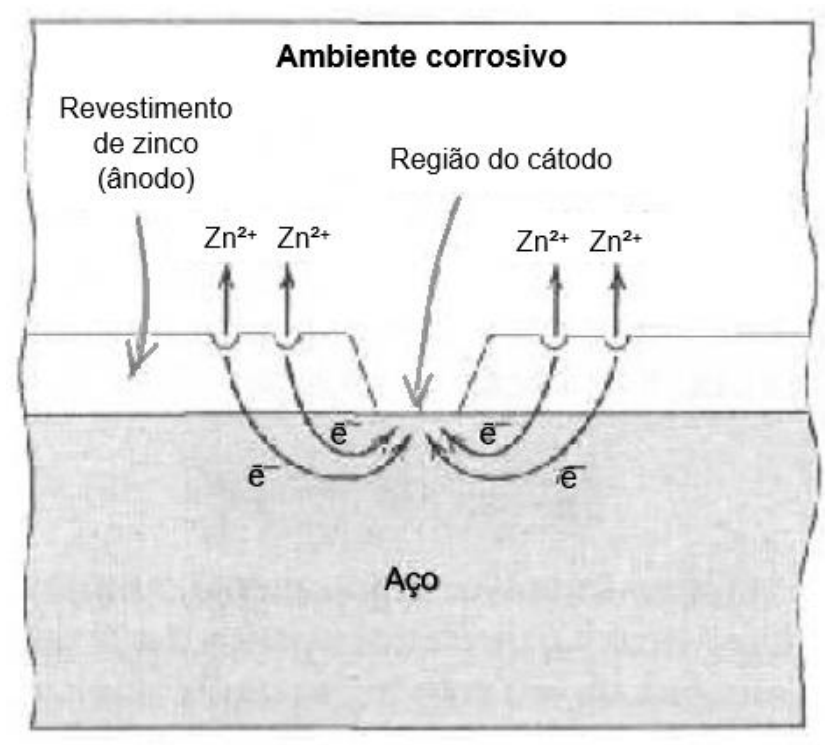

Fonte: [2]

A velocidade de corrosão do zinco quando em soluções aquosas neutras ou atmosferas naturais é relativamente baixa, o que proporciona ao revestimento de zinco uma longa duração. Porém, outros fatores como a natureza do metal e o ambiente em que está exposto podem determinar a velocidade da corrosão [3].

Em soluções neutras, o processo de corrosão do zinco é acompanhado pela formação de películas, produtos de corrosão das áreas anódicas do metal, estas películas são densas e aderentes e atuam como barreira, impedindo a continuação do ataque ao material. Em soluções fortemente ácidas ou alcalinas, ocorre a ausência da formação de películas, então a superfície metálica fica exposta com fácil acesso aos íons hidrogênio, oxigênio e $\mathrm{OH}$, o que aumenta a velocidade de corrosão do revestimento, nestes casos, frequentemente são utilizadas técnicas de pintura sobre o revestimento de zinco, reforçando a proteção anticorrosiva [3].

Na figura 2 é possível observar a taxa de corrosão do zinco (cm/ano) de acordo com o pH do ambiente em que o material está exposto. 
Figura 2 - Efeito do $\mathrm{pH}$ na corrosão do revestimento de zinco

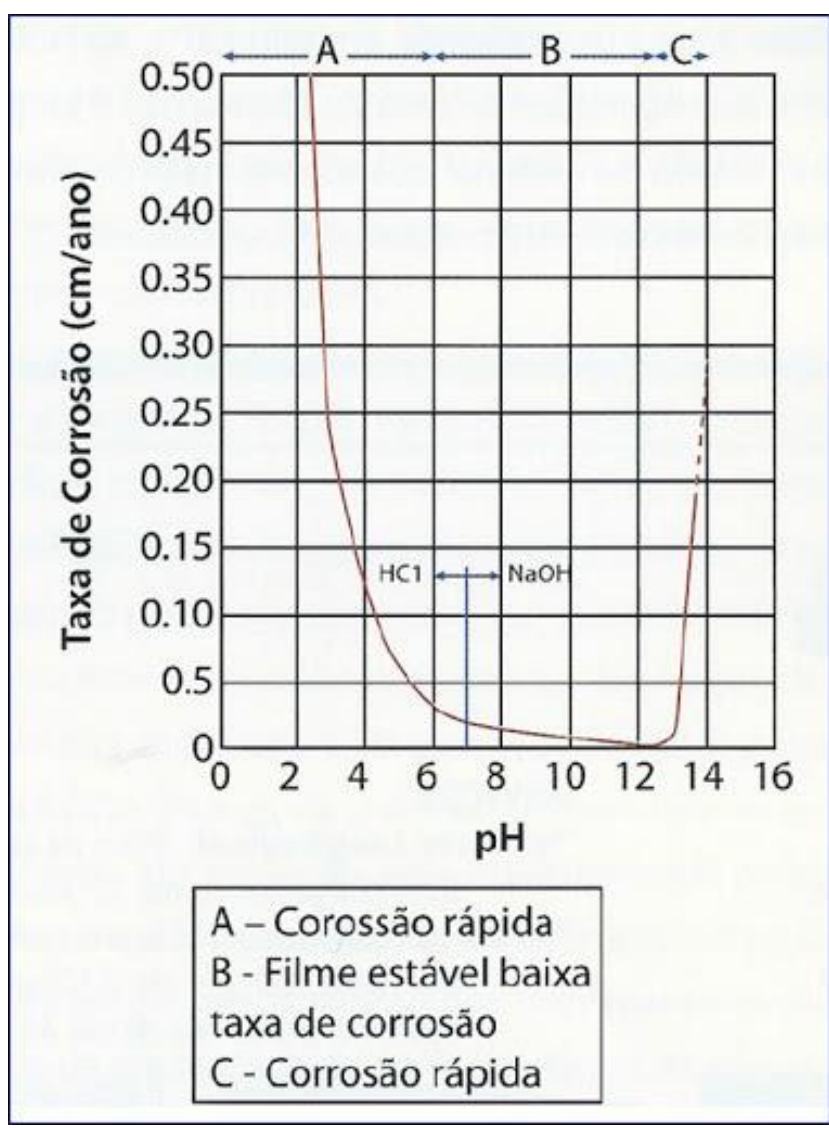

Fonte [15]

A imersão a quente e eletrodeposição são os dois principais processos utilizados para aplicar revestimentos de zinco, há também processos de aspersão térmica (metalização), sherardização e tintas ricas em zinco, mas estes são menos utilizados [7]. O processo de aplicação de revestimento por eletrodeposição consiste na aplicação de uma camada fina e aderente de um metal em uma superfície metálica. É considerado uma técnica econômica, pois é possível conseguir uma proteção adequada com camada de revestimento de poucos micrômetros. É um processo eletrolítico, em que o material que se quer proteger é usado como cátodo e o eletrólito contém o metal, em íons, que será reduzido na superfície da peça. A espessura e propriedades do revestimento aplicado dependem de fatores de controle de processo como temperatura do eletrólito utilizado, densidade da corrente elétrica, concentração de sais, presença de aditivos e características do metal base [20].

A imersão a quente consiste na imersão de peças de aço ou de ferro fundido em um banho de zinco fundido em uma faixa de temperatura entre $440^{\circ} \mathrm{C}-470^{\circ} \mathrm{C}$. Durante a imersão formam-se camadas de liga Zn-Fe aderentes à superfície do aço 
que são progressivamente ricas em zinco, sendo a camada superficial essencialmente constituída por zinco puro [3].

Os revestimentos de zinco, tanto aqueles aplicados por imersão a quente ou eletrodeposição, são chamados de galvanizados. Revestimentos aplicados por processo de eletrodeposição são mais dúcteis que os revestimentos obtidos por imersão a quente. Estes dois tipos de revestimento de zinco possuem velocidade de corrosão comparáveis, porém, revestimentos por imersão a quente tendem a apresentar uma menor ocorrência de corrosão por pites, o que sugere que a presença de compostos intermetálicos deste revestimento é benéfica [5].

\subsection{Galvanização por imersão a quente}

O zinco se funde a uma temperatura de $419,5^{\circ} \mathrm{C}$. A galvanização por imersão a quente consiste na imersão do material em uma cuba contendo zinco fundido em uma temperatura mantida entre $445^{\circ} \mathrm{C}-465^{\circ}$, onde o ferro reage com o zinco fundido e se formam as camadas intermetálicas que compõem o revestimento. Temperaturas cima de $470^{\circ} \mathrm{C}$ intensificam as reações entre o aço e o zinco, gerando mais intermetálicos, podendo ocasionar ataque excessivo às paredes da cuba de galvanização, interferência na aderência da camada, perdas devido à formação de borras na superfície e maior consumo de energia [16, 17].

A camada de zinco presente nos revestimentos de aço galvanizado por imersão a quente é composta por fases intermetálicas intermediárias com teores de ferro e zinco diferente em cada uma delas, sendo respectivamente: fase Gama ( $Г$ ) 75\% Zn -

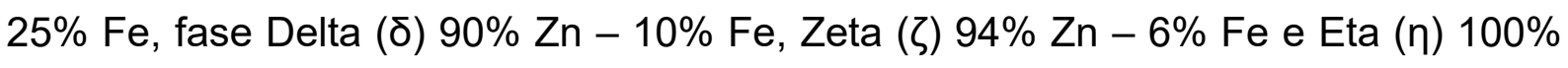
$\mathrm{Zn}$. A qualidade do revestimento, composição das fases e espessura, dependem do controle das reações entre o zinco e o ferro do aço, como: temperatura do banho, tempo de imersão, composição química do banho de zinco e do aço, sistema de saída da peça, velocidade da linha de galvanização, resfriamento do material $[16,18]$.

O tempo de imersão pode variar de 10 a 300 segundos, de acordo com as características da peça a ser galvanizada. Composição química do banho e do material a ser galvanizado também devem ser controlados pois afetam na reação entre o aço e o zinco. O resfriamento do material deve ocorrer rapidamente para 
cessar o crescimento das camadas intermetálicas do revestimento. Este resfriamento pode ser feito em água ou solução de passivação [16, 17].

O aço galvanizado a quente é utilizado em diversos ambientes e oferece resistência à corrosão por décadas. A resistência do material galvanizado por imersão à quente varia de acordo com o ambiente em que o material está exposto. Para uma estimativa da vida útil, as medições da taxa de consumo real do revestimento durante os primeiros anos de utilização podem fornecer bons dados. À medida que os produtos de corrosão do zinco são depositados na superfície, que na sua maioria são aderentes e razoavelmente insolúveis, a taxa de corrosão tende a diminuir com o avanço do tempo [19].

O desempenho final do aço galvanizado, quando exposto na atmosfera, depende de cinco fatores: temperatura, umidade, precipitação, concentração de dióxido de enxofre e salinidade do ar. O tempo para a primeira manutenção é definido a partir de 5\% de presença de corrosão na superfície do aço base, mesmo com 95\% de revestimento ainda intacto, a manutenção é indicada para prolongar a vida útil da estrutura. Portanto, visualizando o Gráfico 1 que se mostra a estimativa de tempo para a primeira manutenção, mesmo em atmosferas industriais, aços galvanizados por imersão a quente podem fornecer, em média, até 70 anos de vida útil [19].

Gráfico 1 - Estimativa do tempo de vida útil de materiais galvanizados

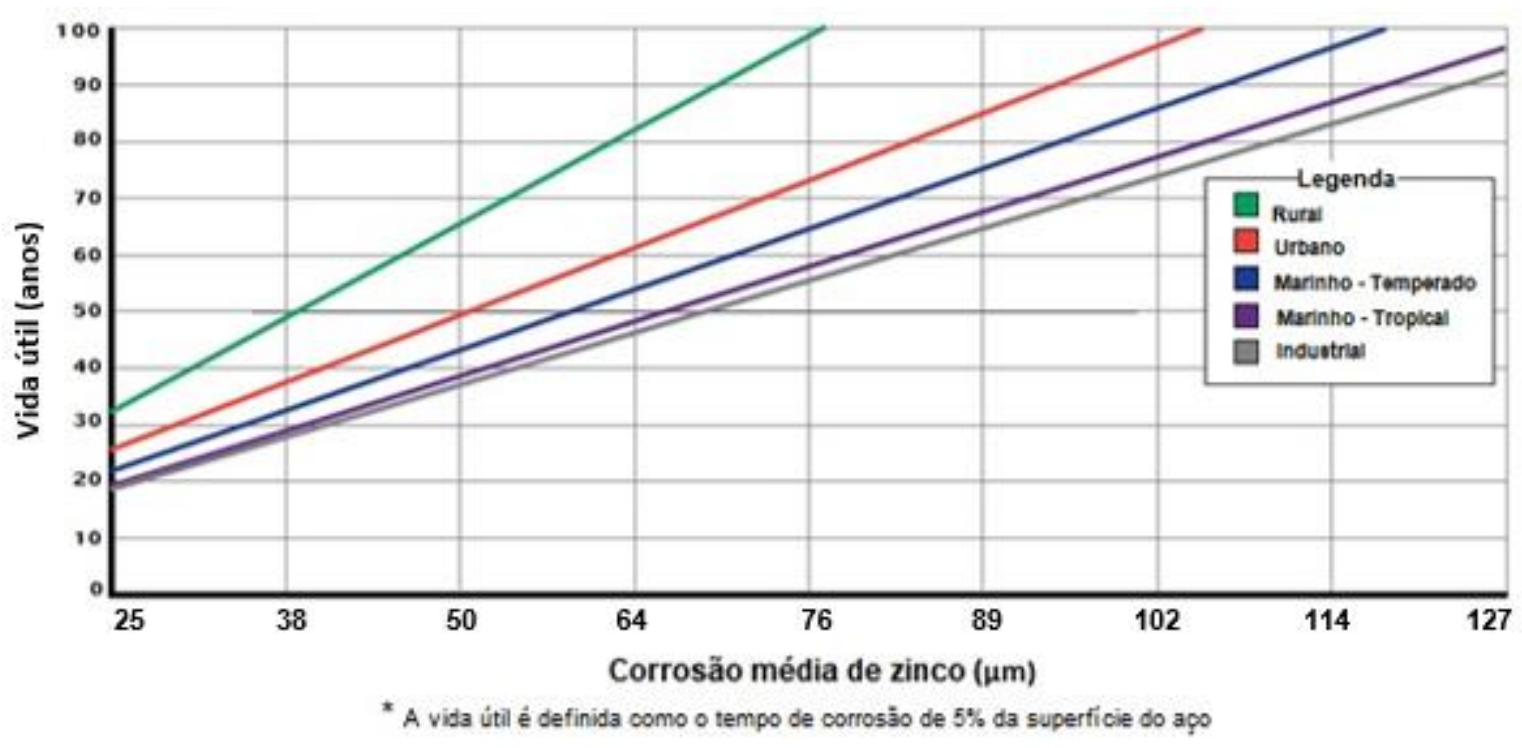

Fonte: adaptado [19]. 
Outra exposição comum para aços galvanizados é a utilização de peças enterradas no solo. Com a diversidade de solos existentes, o desempenho da galvanização é variado e difícil de prever. Fatores como pH, concentração de cloretos e teor de umidade podem determinar o tempo de vida do revestimento. Aeração, temperatura, textura e tamanho de partículas também podem afetar a durabilidade, solos com partículas maiores retiram a umidade da superfície mais rapidamente, logo a peça galvanizada fica menos tempo em exposição a umidade [19].

Sendo a umidade altamente corrosiva para a maioria dos metais, incluindo o zinco, um ambiente menos comum para aço galvanizado é submerso ou exposto à água. No entanto, devido ao desenvolvimento da pátina de zinco passiva, a taxa de corrosão do aço galvanizado é muito mais lenta que o aço sem revestimento. Há muitos tipos diferentes de água (água pura, água doce natural, água potável, água tratada, água do mar) e cada um possui diferentes mecanismos que determinam a taxa de corrosão. Embora $\mathrm{pH}$ tenha um efeito importante na determinação da durabilidade do revestimento, outros parâmetros afetam a corrosão dos metais em ambientes aquáticos, como conteúdo de $\mathrm{O}_{2}$ presente, agitação, presença de inibidores, marés [19].

Para uma galvanização bem sucedida, com um bom revestimento, isento de falhas na aderência do revestimento é de extrema importância a preparação da superfície antes da imersão da peça no banho de zinco [20]. No próximo capítulo será abordado a etapa da preparação da superfície para aplicação do revestimento.

\subsubsection{Preparação da superfície}

A etapa de preparação da superfície é muito importante, isto porque o zinco não reage metalurgicamente com a superfície do aço quando este não está completamente limpo. Uma limpeza eficaz pode ser obtida por diversos processos que consistem basicamente em desengraxe, decapagem e fluxagem. $O$ desengraxe remove óleos, gorduras e outros compostos saponificantes presentes no substrato do aço. O desengraxante utilizado pode ser alcalino ou ácido e normalmente são utilizadas soluções aquecidas em torno de 65ํㅜ [20].

Após o desengraxe, o material deve ser lavado e posteriormente devem ser removidos os óxidos de ferro presentes no substrato utilizando decapagem, que pode 
ser feita em soluções ácidas como $\mathrm{HCl}$ ou $\mathrm{H}_{2} \mathrm{SO}_{4}$. Em seguida, mais uma lavagem e imersão em solução de fluxagem [20].

O tratamento de fluxagem é necessário para dissolver quaisquer resquícios de óxidos de ferro ainda presentes na superfície, proporcionando uma boa aderência do zinco líquido sobre o substrato de aço, o que facilita a interação metalúrgica adequada entre o zinco e o aço [20].

A fluxagem pode ocorrer por dois métodos distintos, de acordo com o processo de galvanização, podendo ser a seco ou úmido. Nos dois métodos é utilizado sal duplo de cloreto de zinco e amônio $\left(\mathrm{ZnCl}_{2}\right.$ e $\left.\mathrm{NH}_{4} \mathrm{Cl}\right)$. No processo de galvanização úmido, as peças a serem galvanizadas, após a etapa de lavagem são encaminhadas para a cuba de galvanização e imersas lentamente em uma camada de sais fundidos na superfície do zinco, formando um colchão que sobrenada o zinco. Neste processo, à medida que a peça é imersa, as impurezas vão sendo dissolvidas e absorvida a umidade residual. No método de galvanização a seco, ilustrado na Figura 3, após a lavagem, as peças são imersas em um banho de solução fluxante, em concentração e temperatura que variam de acordo com as características de cada processo. Como resultado, é obtida uma película seca de fluxante sobre a superfície do aço. Neste método se faz necessário a secagem das peças em uma estufa, tendo como objetivo um melhor rendimento na cuba de galvanização, evitando choques térmicos e consequentes respingos. A temperatura da estufa de secagem deve ser controlada, não podendo ultrapassar $150^{\circ} \mathrm{C}$ para não ocorrer a volatilização excessiva do fluxo [17]. 


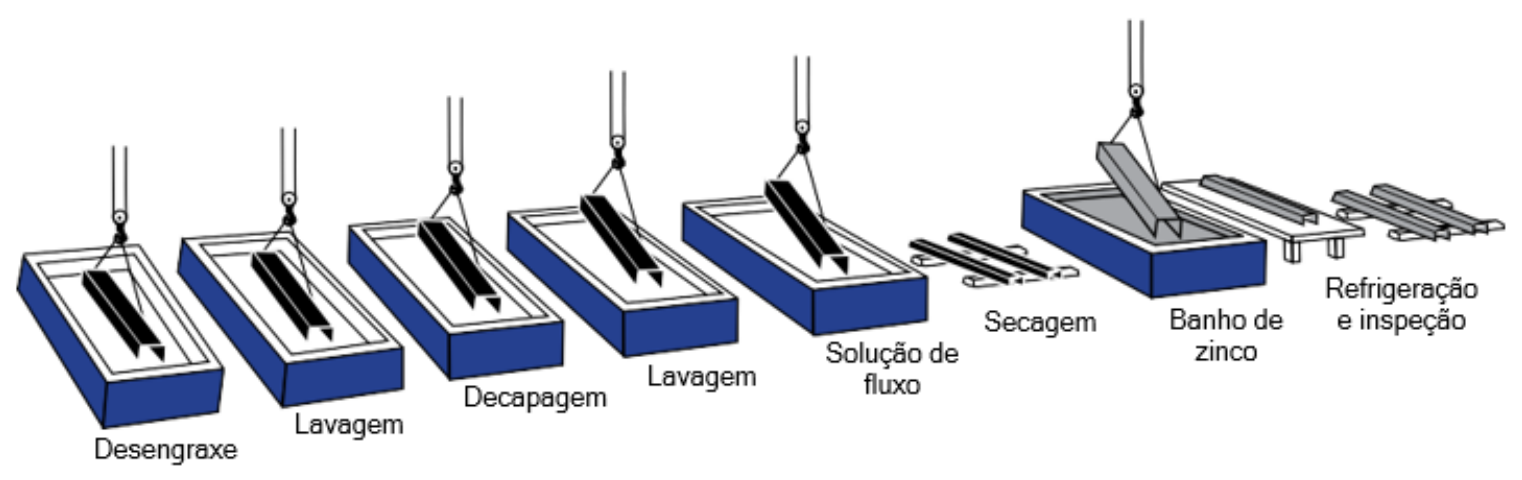

Fonte: adaptado [16].

\subsubsection{Processo de imersão a quente}

Após a limpeza da superfície, as peças são encaminhadas para imersão em zinco fundido em temperatura de $440^{\circ} \mathrm{C}$ a $470^{\circ} \mathrm{C}$, conforme já mencionado anteriormente. $O$ tempo de imersão pode variar de 10 a 300 segundos, de acordo com as características da peça a ser galvanizada, e, no primeiro minuto de imersão, observa-se um crescimento acentuado da camada e em seguida ocorre uma reação mais lenta até determinado limite em que se atinge a estabilidade. Em certos casos, quando os materiais a serem galvanizados são mais pesados, o tempo de imersão é mais longo. [16, 17, 20].

A temperatura do zinco no processo de galvanização deve ser controlada, não sendo recomendável temperaturas acima de $480^{\circ} \mathrm{C}$, pois acelera o processo de dissolução de ferro no zinco, podendo ocasionar efeitos prejudiciais na cuba de galvanização (ataque excessivo), nas peças a serem galvanizadas (aumento de espessura) e causar contaminação no banho pelo excesso de Fe dissolvido [3].

O tempo de imersão é condicionado para assegurar que as peças permanecerão imersas até que as trocas térmicas sejam completas. $O$ equilíbrio térmico é estabilizado a uma dada temperatura, tempos de imersão mais curtos ou mais longos podem resultar em espessuras de camadas de liga menor ou maior, respectivamente, porém, a espessura total passa ligeiramente por um mínimo. O 
controle do tempo de imersão é dado em função da temperatura do banho de zinco, espessura e geometria das peças a serem galvanizadas [3].

Ao ser retirado da cuba de galvanização, o material deve ser resfriado, pois as reações da liga $\mathrm{FeZn}$ podem continuar a difundir-se até a temperatura de $250^{\circ} \mathrm{C}$ mesmo após a solidificação da camada superficial, o que pode converter toda ou parte da camada de zinco puro em liga Fe-Zn, o que torna o revestimento mais opaco e pode alterar algumas propriedades. O resfriamento pode ser realizado em água ou solução de passivação. A utilização de solução de passivação, geralmente utilizando imersão em soluções cromatizantes (ácido crômico e bicromato) tem como finalidade retardar o aparecimento da camada de oxidação branca [3, 17, 21]

Para a velocidade de retirada das peças não existe uma regra, vale o imperativo de obter um revestimento homogêneo e uniforme, porém a velocidade de retirada, em alguns casos, pode afetar o escorrimento do zinco fundido, em que uma retirada rápida pode originar num revestimento espesso e irregular, enquanto uma retirada lenta permite um revestimento de espessura menor e com maior uniformidade [3].

A composição química do banho, do material a ser galvanizado e a geometria das peças também devem ser controlados pois afetam na reação entre o aço e o zinco, influenciando no crescimento da camada de liga. O conhecimento da composição química do aço a ser galvanizado é fundamental na obtenção de um revestimento aderente e uniforme. Aços reativos têm sido um problema, a presença de $\mathrm{Si}$ e $\mathrm{P}$ no aço aumentam significativamente a espessura do revestimento, apresentando uma aparência acinzentada e uma baixa aderência; C e P aceleram o crescimento da camada de liga. Camadas muito espessas de revestimento diminuem a tenacidade do revestimento, podendo causar a ruptura (ou desplacamento). Dentre os aditivos que podem ser incorporados no banho de zinco, elementos como alumínio, magnésio e níquel são adicionados para melhorar o desempenho da imersão a quente. O alumínio é o mais comumente utilizado. A adição de uma pequena quantidade pode auxiliar no controle do crescimento da camada, isto porque o alumínio tem a função de reduzir a taxa de oxidação do zinco fundido e reduzir o tamanho do grão, melhorando a uniformidade do revestimento, pois reage com o $\mathrm{Fe}$ e forma uma camada de inibição densa na interface Fe-Zn, resultando na melhora da molhabilidade do zinco líquido e inibe a formação de fase frágil FeZn no processo de galvanização [ 20, 22, 23, 24]. 
A compreensão das transformações de fases que ocorrem na interface do substrato do aço e Zn são importantes, porém, este entendimento é agravado pelo uso de aditivos no banho de zinco (como adição de alumínio) e também aditivos adicionados ao aço para melhorar as suas propriedades. $O$ uso de aditivos pode afetar as reações Fe-Zn em três fatores [21]:

- várias reações ocorrendo ao mesmo tempo, incluindo a molhabilidade do banho, dissolução do aço, solidificação isotérmica dos compostos intermetálicos e da liga de $\mathrm{Zn}$, transformação de fase difusional em estado sólido;

- a velocidade das reações ocorrem de maneira muito rápida, em alguns casos em menos de 1s;

- a frente de transformação muitas vezes se torna instável e, portanto, não é governada pela termodinâmica de equilíbrio simples.

Baixos teores de $\mathrm{Al}(<1 \%)$ são adicionadas ao banho de Zn para melhorar a molhabilidade do banho, melhorar o brilho do revestimento, reduzir a oxidação do banho de $\mathrm{Zn}$, obter um revestimento dúctil suprimindo formação de fases intermetálicas Fe-Zn. Na prática, concentrações em torno de 0,1 a 0,3 \% em massa de Al é adicionado ao banho para inibir a formação de compostos intermetálicos. A inibição é transitória e afeta no tempo de imersão da peça, que pode aumentar com o aumento do percentual de Al, baixas temperaturas do banho, teor de Fe no banho, dentre outros fatores [21].

\subsubsection{Proteção por barreira}

Os produtos de corrosão do zinco são formados em função da atmosfera do ambiente em que o material está exposto. Como outros metais, o zinco se corrói quando exposto às condições atmosférica. Assim que o material é removido do banho de zinco inicia-se o processo de corrosão em contato com o ar [19].

Um filme de óxido de zinco, resistente à corrosão, é normalmente formado cerca de 24 horas após a galvanização. Esta camada é fina, dura e tenaz, sendo a primeira etapa do desenvolvimento da pátina de zinco, camada protetora conhecida como proteção por barreira. Quando esta camada de óxido de zinco é exposta ao ar atmosférico, reage com a atmosfera e progride para hidróxido de zinco, camada com coloração branco acinzentado, também chamado de corrosão branca. O hidróxido de 
zinco pode se formar de 24 horas até 3 meses após a galvanização, período de tempo vai variar conforme a exposição do material [19].

As camadas de óxido e hidróxido de zinco, durante a secagem, reagem com $\mathrm{CO}_{2}$ da atmosfera e então transformam-se em carbonato de zinco, uma película fina, compacta, resistente, aderente e praticamente insolúvel, também conhecida como pátina de zinco, representados na Figura 4. Esta camada oferece proteção por barreira e seu período de formação pode levar de 3 a 12 meses após a galvanização [19].

Figura 4 - Esquema de formação da proteção por barreira
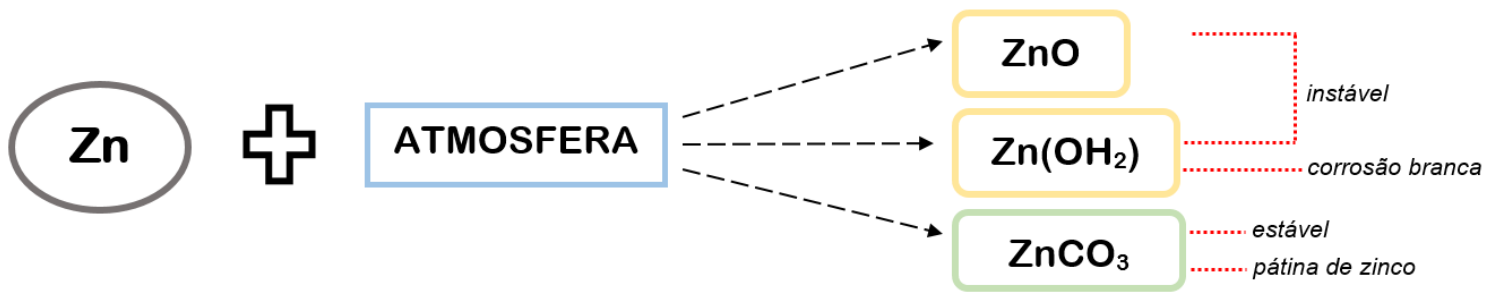

Fonte: adaptado [16]

Para que esta camada de proteção por barreira se forme é de importância primordial que a superfície galvanizada tenha tempo hábil. Como o $\mathrm{ZnCO}_{3}$ é renovável está sendo substituído continuamente pelas camadas subjacentes do zinco e ligas de Fe-Zn. A camada de $\mathrm{ZnCO}_{3}$ corrói-se lentamente e é considerada insolúvel, consequentemente, protege a camada mais espessa de revestimento de $\mathrm{Zn}$ e resulta em vida útil mais longa. Ainda assim, o revestimento de zinco fornece proteção catódica. A proteção catódica é ativada somente quando o aço e o zinco são expostos ao ambiente [19].

\subsubsection{Camadas intermetálicas}

O zinco (fase líquida) reage com o ferro presente no aço (fase sólida) e, por difusão, formam as camadas de liga $\mathrm{Zn}-\mathrm{Fe}$, compostos intermetálicos sólidos com características mecânicas e durezas diferentes. Todas estas transformações são comandadas pela reação de difusão de $\mathrm{Zn}$ no substrato do aço. No entanto, Fe 
provavelmente também se difunde para fora das fases de liga em direção ao Zn, mas a uma taxa muito mais lenta [21].

O diagrama de fases Fe-Zn de Kubacheswski é o mais amplamente aceito e segue representado na Figura 5.

Figura 5 - Diagrama de fases Fe-Zn de Kubaschewski

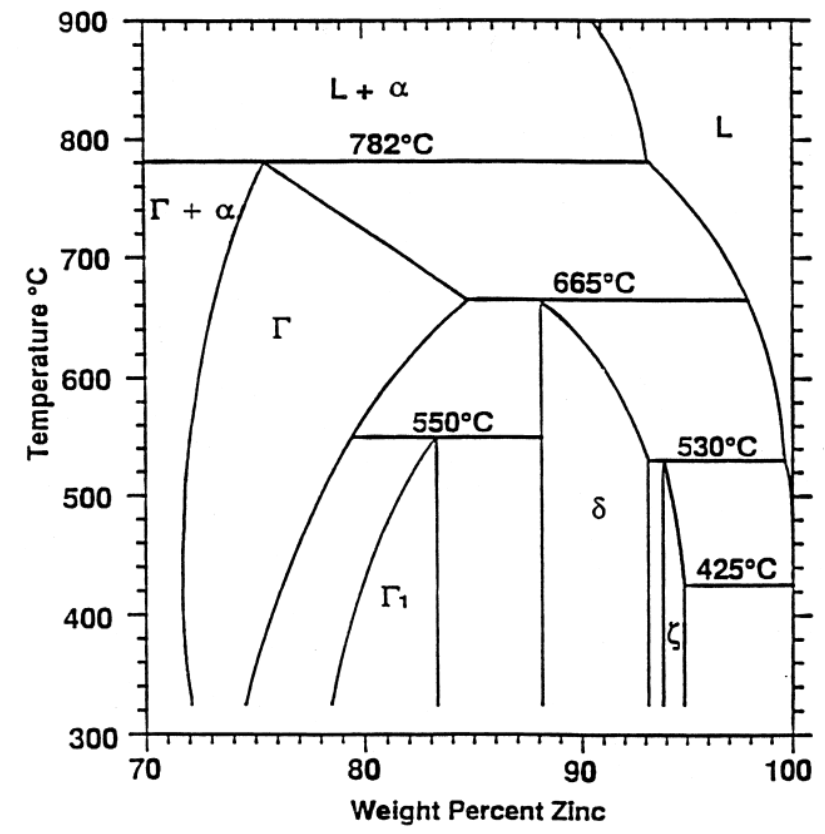

Fonte: [21]

A seguir, uma breve descrição das fases intermetálicas Fe-Zn encontradas em revestimentos galvanizados por imersão a quente, segundo [21], em ordem crescente de acordo com o teor de Fe presente em cada uma das fases:

- Fase Eta (n): camada de fase que possui estrutura HCP, é formada no momento da retirada da peça do banho de zinco. Embora não representada no diagrama de fases Fe-Zn, a camada de fase eta tem uma solubilidade de 0,03\% de Fe, correspondente ao percentual de Fe presente no banho de zinco [3, 21].

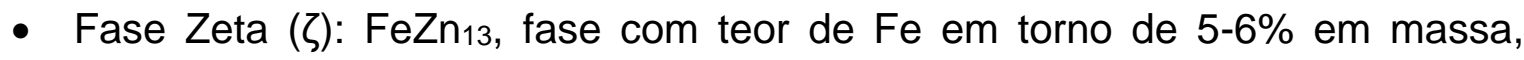
formada pela reação peritética entre a fase delta $(\delta)$ e o zinco líquido a uma temperatura de $530^{\circ} \mathrm{C}+/-10^{\circ} \mathrm{C}$. Fase isomorfa com uma célula unitária monoclínica e estrutura atômica que contém um átomo de ferro e um átomo de zinco rodeados por 12 átomos de zinco nos vértices de um icosaedro ligeiramente torcido que se ligam em um conjunto formando cadeias, e as 
cadeias formando uma matriz hexagonal. A morfologia desta camada de fase é colunar e supersaturada em Fe [21];

- Fase Delta (ס): FeZn ${ }_{10}$, fase com composição de Fe entre 7-11,5\% em massa, formada por uma reação peritética entre a fase gama $(Г)$ e o zinco líquido, à $665^{\circ} \mathrm{C}$. Possui morfologia colunar como resultado de um crescimento perpendicular preferencial ao longo da direção do plano basal da estrutura. Após algum tempo, trincas formam-se ao longo do plano basal da fase delta e que podem estender-se até a fase zeta [21];

- Fase Gama 1 (Г1): Fe5Zn21, composição de Fe de 17 a $19,5 \%$ a $450^{\circ} \mathrm{C}$. Camada ininterrupta, formada pela reação peritetóide entre as fases gama $(\Gamma)$ e a fase delta $(\delta)$ a $550^{\circ} \mathrm{C}+/-10^{\circ} \mathrm{C}$, possui estrutura cúbica de face centrada. Pode ser produzida mediante aquecimento em baixas temperaturas por longos períodos. Esta fase apresenta maior microdureza [21];

- Fase Gama (Г): $\mathrm{Fe}_{3} Z_{n_{10}}$, fase com composição de Fe em torno de 23,5 a $28 \%$ em massa. Formada pela reação peritética entre ferro alfa e o zinco líquido em uma temperatura de $782^{\circ} \mathrm{C}$, possui estrutura cúbica de corpo centrado (CCC) e solubilidade máxima de $\mathrm{Fe}$ até $665^{\circ} \mathrm{C}$. Esta fase é muito fina, de difícil visualização, por tal motivo fases Gama e Gama 1 são consideradas uma fase só. Sua morfologia típica parece como uma camada fina em uma interface planar entre o aço e a fase delta. [21].

Na figura 6, é possível observar a microestrutura do revestimento de zinco e as camadas de fase intermetálicas. 
Figura 6 - Microestrutura do revestimento de zinco

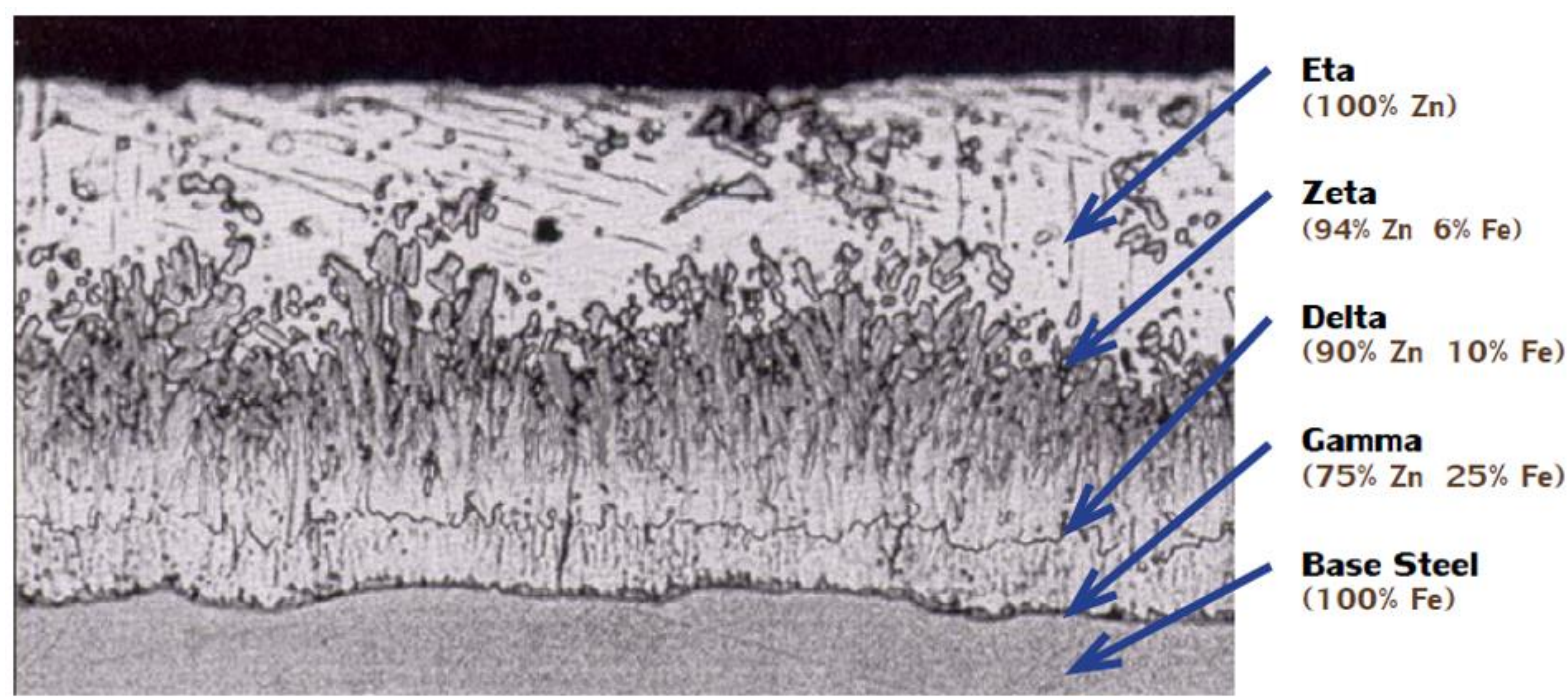

Fonte: [19]

Cada camada exibe uma cinética de crescimento diferente, em imersões de até 300 s à $450^{\circ} \mathrm{C}$, a camada de fase zeta cresce rapidamente no início e depois desacelera, enquanto a fase delta cresce de maneira lenta e com o passar do tempo a espessura aumenta rapidamente, a fase gama ( 1 e 2) necessita de longo período de imersão e atinge espessura máxima na ordem de 1 a $2 \mu \mathrm{m}$. Na Figura 7, é possível observar o esquema de nucleação sequencial das fases, onde o esquema de reação é representado pelo tempo zero (t0) e o desenvolvimento das fases vai ocorrendo de acordo com o tempo, de maneira que, $\mathrm{t} 0<\mathrm{t} 1<\mathrm{t} 2<\mathrm{t} 3<\mathrm{t} 4$, iniciado pela fase zeta, seguido por delta e, após um tempo de incubação de aproximadamente 30s, a fase gama [21]. 
Figura 7 - Representação esquemática da formação das camadas de fase Fe-Zn

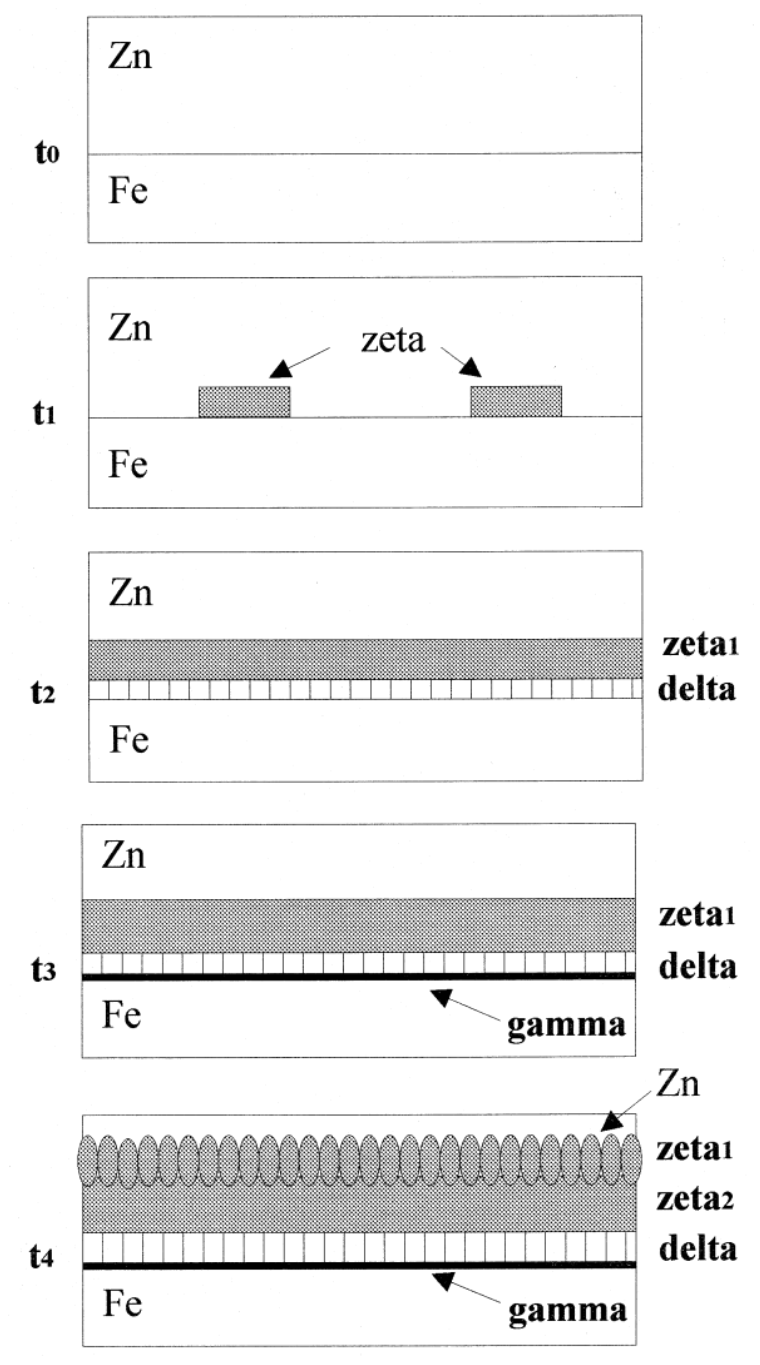

Fonte: [21]

Exceto a camada eta $(\eta)$, todas as camadas de liga presentes no revestimento possuem dureza elevada e baixa ductilidade. Para obter um revestimento dúctil, podendo o material galvanizado ser dobrado sem causar trincamento, a formação de camadas intermetálicas deve ser reduzida ou nula. Esta situação é a que se procura obter na galvanização de fios e arames [3].

Enquanto a primeira camada da $\mathrm{Zn}-\mathrm{Fe}$ (gama) é constante, com aproximadamente 1 a $2 \mu \mathrm{m}$ de espessura, as demais camadas podem variar em função das condições de galvanização, tais como: temperatura do banho, rugosidade da superfície, tempo de imersão, composição do aço, teor de alumínio no zinco, etc. [17]. 


\subsection{Tubulações de aço carbono}

Tubulações de aço são utilizadas nos mais diversos segmentos. Podem ser tubulações de aço com costura ou tubulações de aço sem costura. Apesar de serem visualmente semelhantes, apresentam diferenças significativas no processo produtivo e aplicações [25].

Tubulações de aço sem costura são produzidas com o processo de conformação plástica de tarugos ou lingotes de seção circular, conhecido como extrusão. Tubulações de aço com costura são produzidas com a conformação a frio da chapa de aço por rolos cilíndricos, unida por soldagem em resistência elétrica de alta frequência (ERW) $[25,26]$.

Tubulações com costura em aço carbono são utilizadas para fins industrial, mecânico ou estrutural. Dentre as principais aplicações, podemos citar o uso automobilístico, mobiliário urbano, eletrodomésticos, implementos agrícolas e rodoviários, energia e naval, estruturas, esquadrias. Para cada um destes produtos há um aço específico, variando a composição química e espessura, de acordo com as propriedades desejadas em cada uso. Estes tubos podem apresentar características especiais quanto ao seu aspecto superficial, revestimento, seção, formato, diâmetro, comprimento e outros requisitos [8].

Considerando a aplicação da tubulação de aço carbono com costura para condução de fluidos não corrosivos como água, vapor, óleo e gás, elas são classificadas conforme a ABNT NBR 5580:2015 como tubos pretos (produzidos com a chapa de aço laminada a quente - Figura 8) e tubos galvanizados (tubulações de aço com revestimento protetor de zinco - Figura 9) [8]. 
Figura 8 - Tubos de aço carbono, em seção circular, com costura, pretos

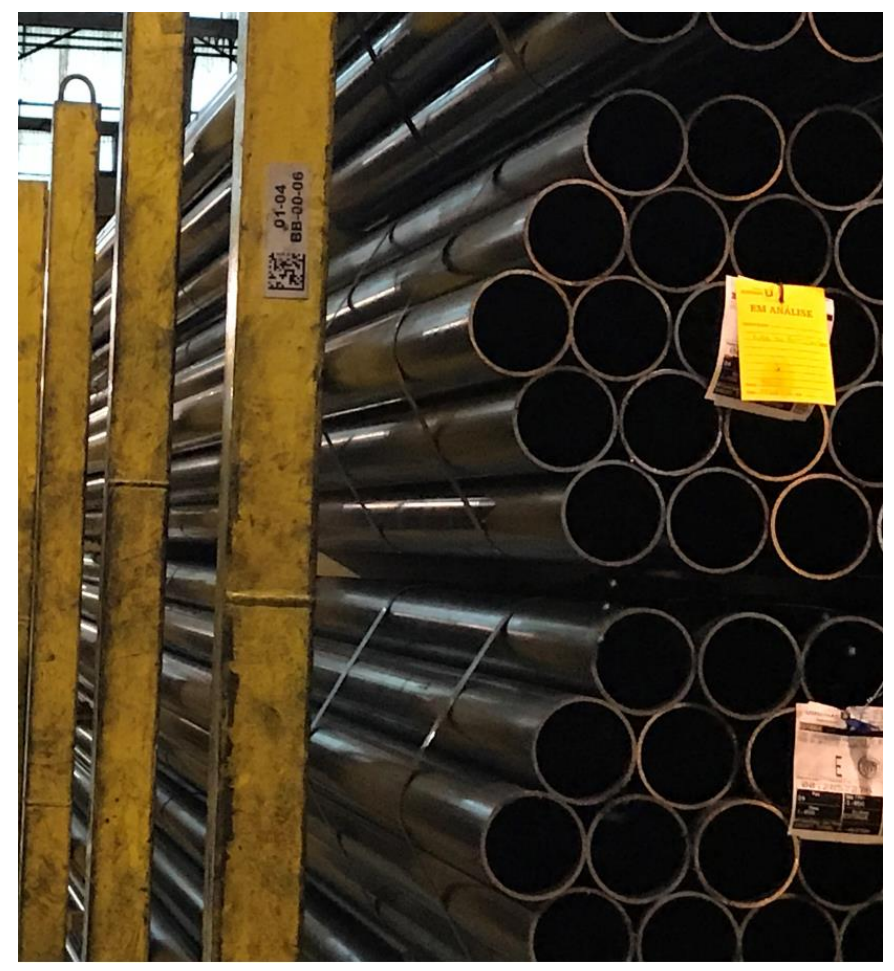

Figura 9 - Tubos de aço carbono, em seção circular, com costura, galvanizados

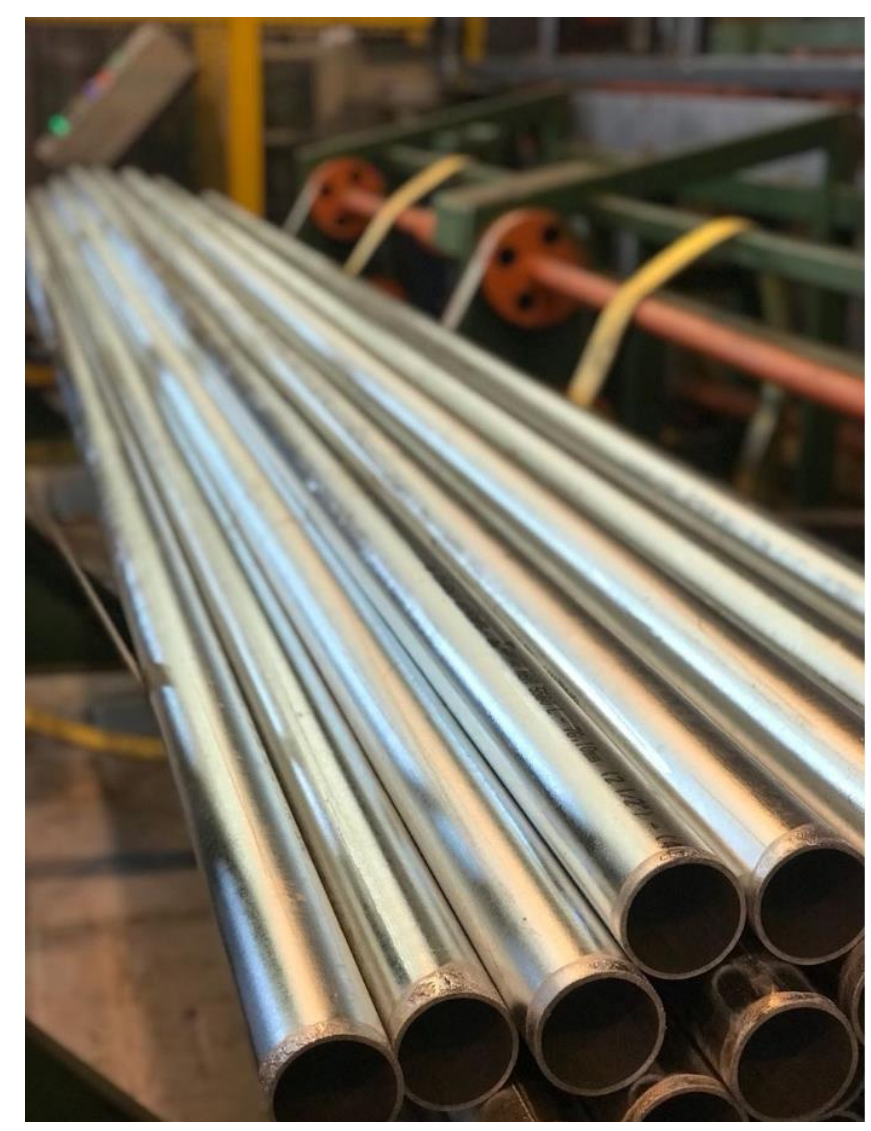


Este trabalho aprofundará os experimentos em tubos de aço carbono, de seção circular, com costura, galvanizados.

\section{PROCEDIMENTO EXPERIMENTAL}

O procedimento experimental adotado neste trabalho consta de duas etapas: na primeira etapa foram retiradas amostras de tubos galvanizados que foram produzidos em um processo de galvanização sem sistema de controle automatizado do tempo de imersão, chamado neste trabalho de Processo 1. Estas amostras tiveram os revestimentos de zinco caracterizados. Na segunda etapa foram retiradas amostras de tubos galvanizados que foram produzidos em um processo de galvanização com processo de controle automatizado do tempo de imersão, chamado neste trabalho de Processo 2. Estas amostras também tiveram o revestimento de zinco caracterizado, permitindo assim uma comparação com o Processo 1.

Os tubos utilizados tanto no processo 1 quanto no 2, são tubos de aço de baixo carbono. A empresa possuía controle da composição química da matéria prima a fim de evitar utilização de aços reativos no processo de galvanização. A Tabela 1 contém a composição nominal dos tubos conforme fornecido.

Tabela 1 - Composição química nominal do aço.

\begin{tabular}{l|r|r|r|r|r|r} 
& Carbono & \multicolumn{1}{c}{ Silício } & Fósforo & Manganês & Alumínio & Enxofre \\
\hline amostra 1 & 0,06 & 0,01 & 0,019 & 0,39 & 0,036 & 0,007 \\
\hline amostra 2 & 0,08 & 0,01 & 0,015 & 0,39 & 0,031 & 0,008 \\
\hline amostra 3 & 0,05 & 0,02 & 0,013 & 0,33 & 0,031 & 0,006 \\
\hline
\end{tabular}

Fonte: análises realizadas e fornecidas pela empresa

A seguir serão descritos todos os procedimentos para cada um dos processos.

\subsection{Processo 1}

Na Figura 10 estão representadas as etapas do processo de galvanização sem processo de controle automatizado, chamado, aqui neste trabalho, de processo 1. 
Figura 10 - Fluxograma do processo de galvanização de tubos no processo 1.

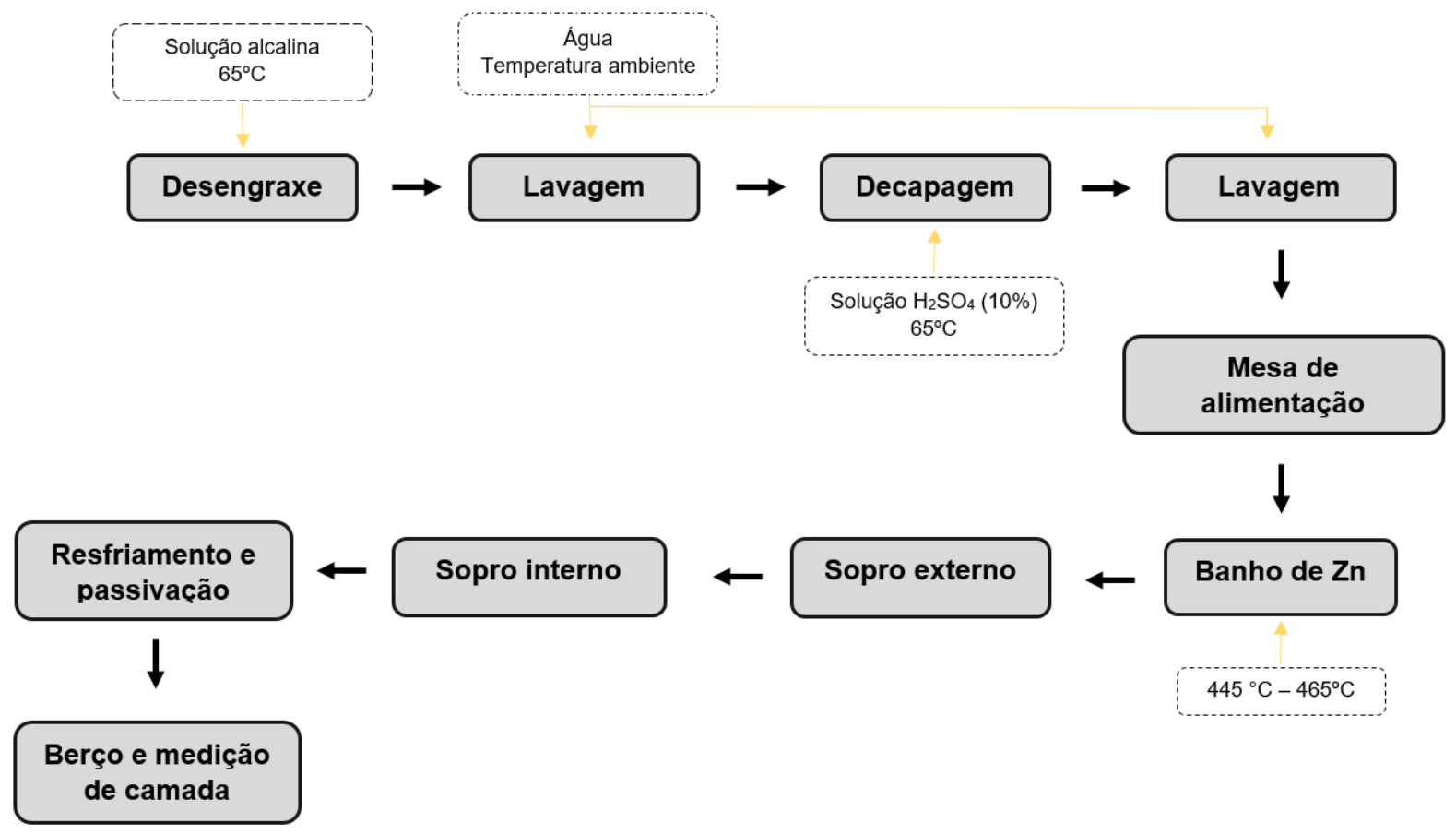

Fonte: próprio autor.

O processo inicia na etapa de preparação da superfície, em que os tubos eram imersos nos banhos, transportados em lotes. A sequência de imersão era conforme apresentada no fluxograma, desengraxe (solução alcalina 10\% (água+ $\mathrm{NaOH}$ ), aquecida a aproximadamente $65^{\circ} \mathrm{C}$, lavagem em água, decapagem em solução ácida 10 a $15 \%$ (água $+\mathrm{H}_{2} \mathrm{SO}_{4}$ ), aquecida a aproximadamente $70^{\circ} \mathrm{C}$; lavagem em água e em seguida, os tubos eram encaminhados para uma mesa de alimentação que transportava os lotes de tubos para a cuba de galvanização. Antes de entrar em imersão com o banho de zinco, os tubos passavam pelo "colchão de amônia", cloreto de amônia em forma sólida disposta em cima do banho de zinco.

Para controle do tempo de imersão dos tubos, havia um temporizador com sinal sonoro, que disparava o sinal no momento que os tubos do lote deveriam ser imersos na cuba. A imersão era feita com o auxílio de um "afogador" que empurrava os tubos, um a um, para dentro do banho de zinco. Após todos os tubos do lote imersos, iniciava-se a contagem do tempo para retirada, entre 180 s e 300 s, variando conforme o material a ser galvanizado. Após o tempo estabelecido, um sinal sonoro era emitido sinalizando o momento da retirada dos tubos. A retirada ocorria um tubo por vez, de maneira manual, com ferramenta. Após a retirada do tubo, este passava por um 
soprador externo, que aplicava um jato de ar comprimido sobre a superfície externa dos tubos para retirada do excesso de zinco, e então encaminhado para uma esteira via rolos que encaminhava o tubo para o sopro interno, que ocorria com um jato de ar comprimido na parte interior do tubo, para retirada do excesso de zinco, e em seguida os tubos eram encaminhados para imersão em solução $(\mathrm{pH} 4,5)$ para passivação e resfriamento. Em seguida, os tubos eram retirados da imersão e encaminhados por uma esteira até o berço, local onde o lote de tubos permanecia armazenado até ser inspecionado e finalizado. Na Figura 11 é mostrada a ilustração do processo de galvanização.

Figura 11 - Ilustração do processo de galvanização no processo 1

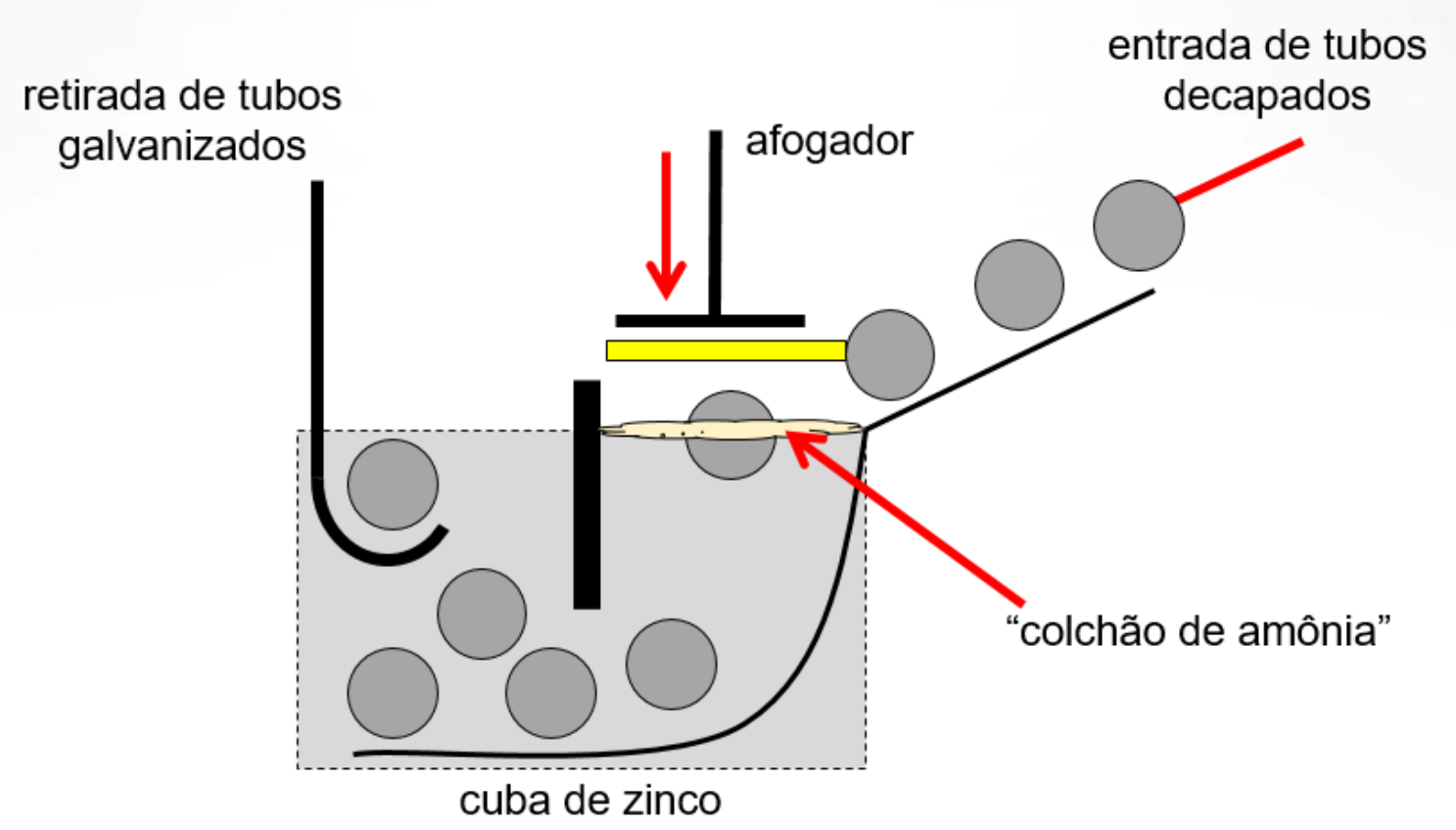

Fonte: cedido pela empresa.

A atividade de retirada dos tubos neste processo não garantia que o primeiro tubo a entrar na cuba era o primeiro tubo a sair da cuba, ou seja, havia uma variação aleatória do tempo que cada tubo permanecia em imersão, o que poderia resultar em pouco controle sobre a espessura da camada de revestimento. 


\subsection{Processo 2}

No processo 2 ocorreram algumas mudanças, sendo a principal a retirada automatizada dos tubos de dentro do banho de zinco com controle do tempo de imersão e também alterações nas etapas de limpeza de superfície. Todas as alterações realizadas em relação ao processo 1 estão destacadas com um contorno vermelho e preenchimento amarelo.

$\mathrm{Na}$ Figura 12 estão representadas as etapas do processo de galvanização com controle automatizado, chamado, aqui neste trabalho, de processo 2 .

Figura 12 - Fluxograma do processo de galvanização de tubos no processo 2

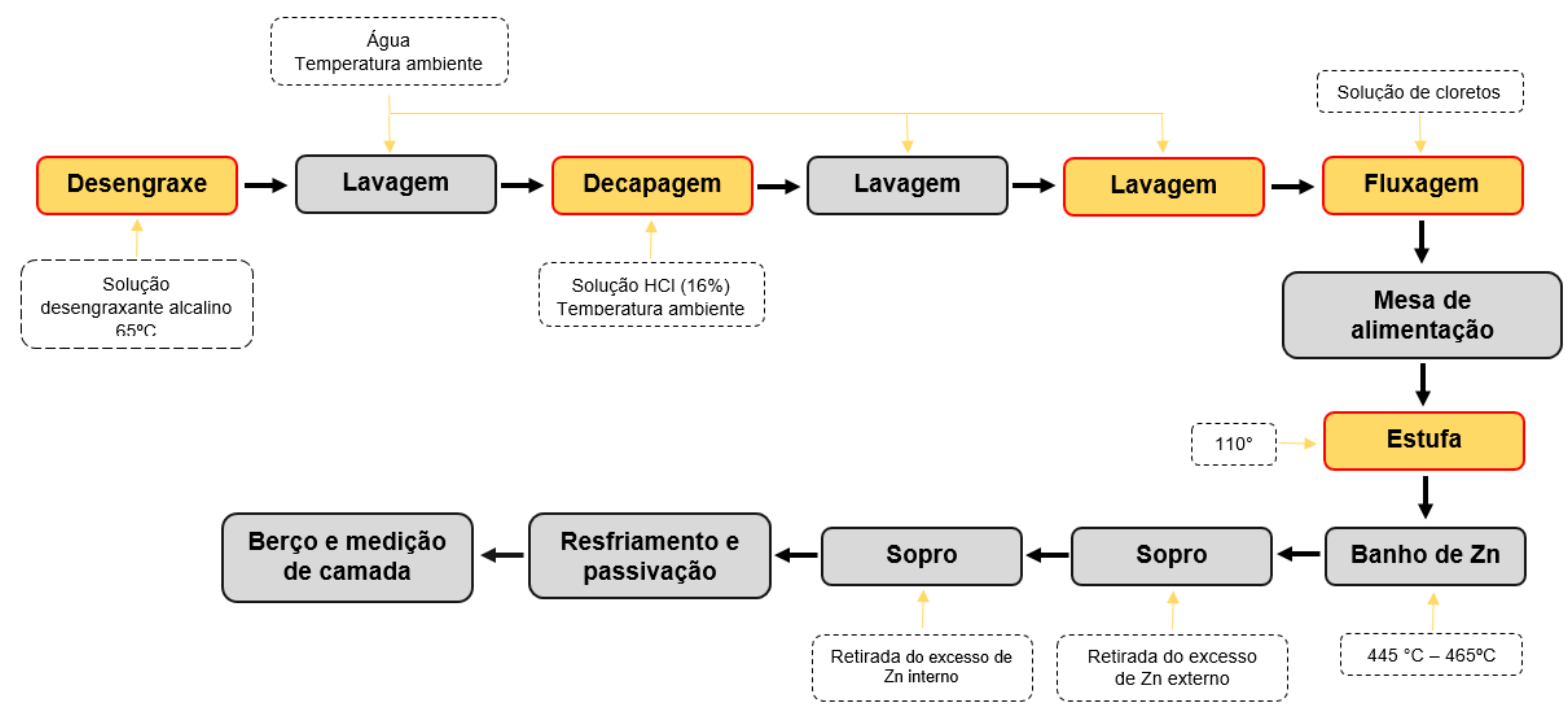

Fonte: próprio autor

Assim como no processo 1, o processo 2 inicia-se na etapa de preparação de superfície, e, nesta etapa ocorreram algumas mudanças nos insumos e banhos para a limpeza. O desengraxe passou a ser feito por solução de desengraxante alcalino (concentração aproximada de $20 \mathrm{~g} / \mathrm{L}$ ) em banho aquecido à aproximadamente $65^{\circ} \mathrm{C}$, seguido de imersão em água, decapagem em solução ácida de $\mathrm{HCl}$ (12 a 16\%) em temperatura ambiente e após a decapagem os tubos são imersos em sequência em dois tanques de lavagem com água. Antes de posicionar o lote de tubos na mesa de alimentação, eles são imersos em um tanque de fluxagem aquecida em aproximadamente $45^{\circ} \mathrm{C}$ (solução de cloreto duplo de amônia e zinco em densidade 
aproximada de $30^{\circ} \mathrm{Be}$ ), em substituição ao cloreto de amônia disposto em cima do banho de zinco. Após imersão em solução de fluxagem, o lote de tubos é disposto na mesa de alimentação e então direcionado por esteira via rolos até a estufa (temperatura entre $110^{\circ} \mathrm{C}-150^{\circ} \mathrm{C}$ ) para secagem antes do contato com o zinco, e em seguida encaminhado para a cuba de galvanização. A entrada na cuba de galvanização passou a ocorrer com sistema de controle automático por tempo, a fim de garantir o tempo de imersão necessário para a camada de revestimento desejada. Os tubos entram um a um na cuba, através de uma estrutura denominada helicoidal com controle automatizado e tempo programado entre as imersões para garantir que os tubos possam ir entrando e saindo na sequência correta, com tempo de imersão entre 180 s e 300 s, variando conforme o material a ser galvanizado. Após a retirada da imersão o processo segue com a etapa de soprador externo, soprador interno, resfriamento e passivação e posteriormente encaminhado ao berço de armazenamento de tubos e medição de camada.

$\mathrm{Na}$ Figura 13 a seguir é possível visualizar a ilustração do processo de galvanização. 
Figura 13 - llustração do processo automatizado de galvanização de tubos no processo 2

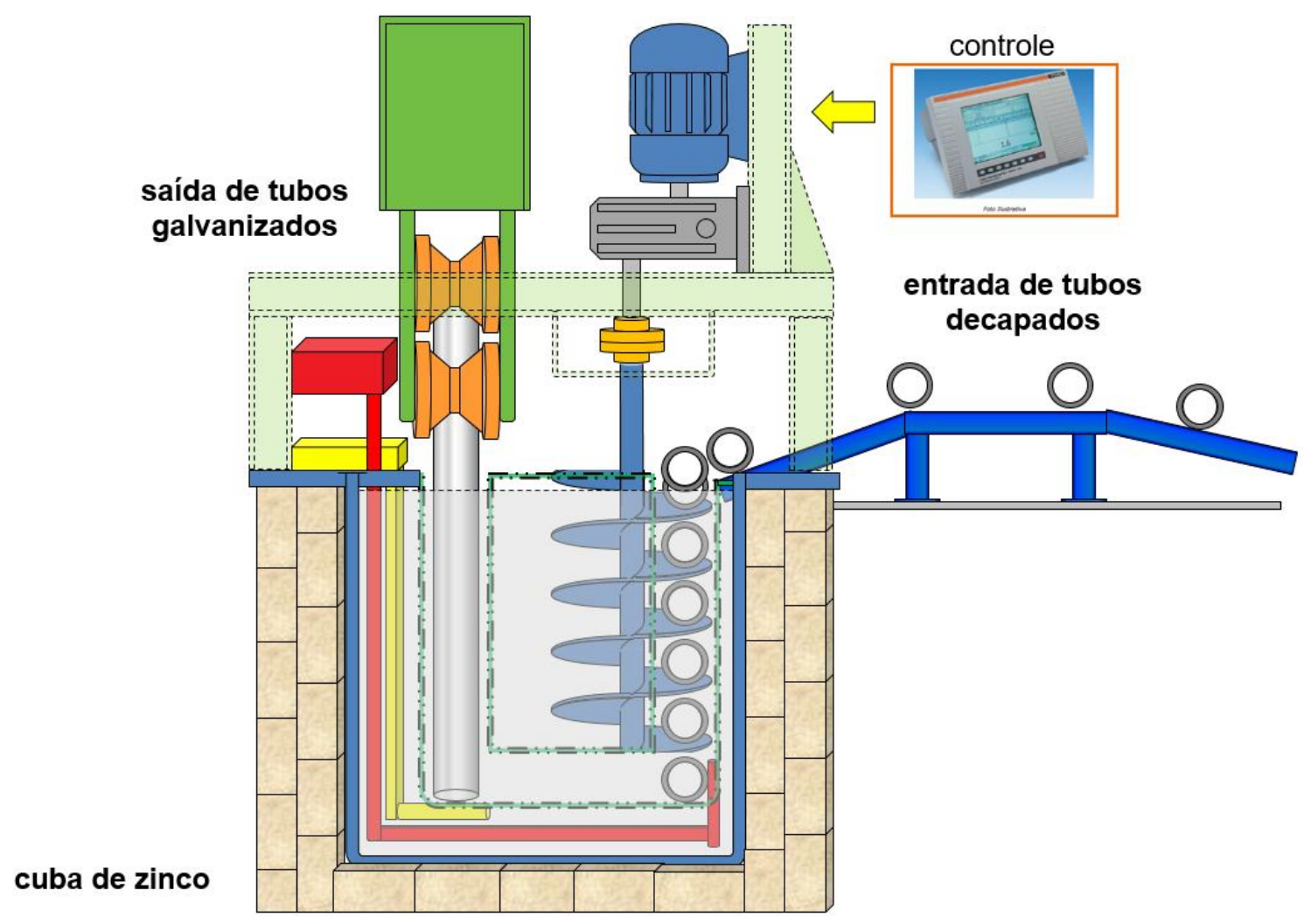

Fonte: cedido pela empresa.

Em ambos os processos é utilizado como composição do banho de zinco o Zn SHG (Special High Grade) com pureza igual a 99,995\% e realizada adição de alumínio a fim de melhorar o escorrimento e brilho das peças galvanizadas e a temperatura da cuba de galvanização era mantida entre $445^{\circ} \mathrm{C}-465^{\circ} \mathrm{C}$. Cabe também mencionar que os tubos são produzidos pela própria empresa, o que proporciona controle sobre o material a ser galvanizado, evitando aços reativos.

De acordo com a ABNT NBR 6323:2016 [27], o percentual máximo de alumínio em massa no banho de zinco para galvanização por imersão a quente de produtos de aço ou ferro fundido é de $0,1 \%$. O resultado das análises das amostras coletadas no banho de zinco no processo 2 foram fornecidas pela empresa e podem ser observados na Tabela 2. 
Tabela 2 - Composição (\%) de zinco e alumínio no banho de zinco.

\begin{tabular}{l|c|c} 
& Zn (\%) & Al (\%) \\
\hline Amostra 1 & 99,88 & 0,002 \\
\hline Amostra 2 & 99,88 & 0,02
\end{tabular}

\subsection{Ensaios de Caracterização}

Para realização dos ensaios e avaliação da qualidade do revestimento dos tubos galvanizados foram escolhidos três diâmetros de tubos, sendo estes $21,30 \mathrm{~mm}$, $60,30 \mathrm{~mm}$ e $76,10 \mathrm{~mm}$ e retirados corpos de prova do processo 1 e do processo 2 , ambos com tempo médio de imersão de 180s.

Para realização de todos os ensaios, os corpos de prova foram identificados da seguinte maneira:

\begin{tabular}{|c|c|c|}
\hline Diâmetro & $\begin{array}{c}\text { Processo } 1 \\
\text { (P1) }\end{array}$ & $\begin{array}{c}\text { Processo } 2 \\
\text { (P2) }\end{array}$ \\
\hline \multirow{3}{*}{$\begin{array}{c}21,30 \mathrm{~mm} \\
(1)\end{array}$} & $1 \mathrm{~A}$ & $1 \mathrm{~A}$ \\
\hline & 1B & 1B \\
\hline & $1 \mathrm{C}$ & $1 \mathrm{C}$ \\
\hline \multirow{3}{*}{$\begin{array}{c}60,30 \mathrm{~mm} \\
(2)\end{array}$} & $2 \mathrm{~A}$ & $2 \mathrm{~A}$ \\
\hline & $2 \mathrm{~B}$ & $2 B$ \\
\hline & $2 \mathrm{C}$ & $2 \mathrm{C}$ \\
\hline \multirow{3}{*}{$\begin{array}{c}76,10 \mathrm{~mm} \\
\text { (3) }\end{array}$} & $3 \mathrm{~A}$ & $3 A$ \\
\hline & 3B & $3 B$ \\
\hline & $3 C$ & $3 C$ \\
\hline
\end{tabular}

Para a realização do teste de verificação da espessura do revestimento de zinco, através de ensaio não destrutivo, utilizou-se como referência a ABNT NBR 7399:2015 [28], em que as peças galvanizadas do processo 1 e 2 foram verificadas em dez pontos distintos com equipamento medidor de espessura ultrassônico marca Instrutherm e considerado como resultado a média das medições. 
Para a escolha e realização dos testes de espessura, uniformidade do revestimento e achatamento, foi utilizado como referência a ABNT NBR 5580:2015 que aborda sobre tubos de aço carbono para usos comum na condução de fluidos [9].

Nos ensaios de verificação de massa do revestimento, os corpos de prova foram submetidos ao ensaio destrutivo pelo método gravimétrico, descrito na ABNT NBR 7397:2007 [29], em que os corpos de prova são limpos, pesados em balança de precisão, e imersas em solução de cloreto de antimônio III até remoção do revestimento, limpos e pesados novamente. O ensaio de uniformidade de revestimento, Ensaio de Preece, foi realizado utilizando a metodologia de descrita na ABNT NBR 7400: 2015 [30], utilizando solução de sulfato de cobre em densidade de $1,186 \mathrm{~g} / \mathrm{cm}^{3}$ e 4 imersões em cada corpo de prova a fim de verificar a presença de trincas no revestimento.

O ensaio de achatamento foi realizado utilizando o método 2 descrito na ABNT NBR 6154:2015 [31], em que os tubos foram posicionados em prensa hidráulica e aplicada carga com velocidade $50 \mathrm{~mm} / \mathrm{min}$, em prensa de ensaio marca RD Hidráulica. Ambos testes foram realizados em triplicata.

A verificação das fases intermetálicas foi realizada com análise metalográfica em microscópio ótico, marca Zeiss e também visualizado com MEV e análise da composição química das fases com a técnica de Espectroscopia por energia dispersiva (EDS) em equipamento marca Phenon World. Para a verificação das fases intermetálicas em microscópio, os corpos de prova foram preparados, na seguinte sequência: corte de amostra e embutimento, lixamento nas lixas de gramaturas 220 , 320, 400, 600 e 1000, polidas com alumina $1 \mu \mathrm{m}$ e atacadas em solução alcoólica de Nital $1 \%$.

O ensaio de névoa salina foi realizado em câmara de névoa salina, marca Bass utilizando como referência a ABNT NBR 8094:1983 [32]. Os corpos de prova foram mantidos em névoa salina com acompanhamento até aparecimento das primeiras marcas de oxidação até o grau mais elevado de oxidação.

\section{RESULTADOS E DISCUSSÃO}

\subsection{Ensaios de Espessura de Camada, Uniformidade e Achatamento}


Os resultados obtidos nos ensaios podem ser visualizados na tabela 1 (processo 1) e na tabela 2 (processo 2).

Tabela 4 - Ensaios realizados com amostras do processo 1

\begin{tabular}{|c|c|c|c|c|c|c|c|c|}
\hline & & \multicolumn{4}{|c|}{ Espessura de camada } & \multirow{2}{*}{\multicolumn{2}{|c|}{$\begin{array}{l}\text { Uniformidade da } \\
\text { camada } \\
\text { (Ensaio de Preece) }\end{array}$}} & \multirow{3}{*}{$\begin{array}{c}\text { Achatamento } \\
\text { Resultado }\end{array}$} \\
\hline & & \multicolumn{2}{|c|}{ Ensaio não destrutivo } & \multicolumn{2}{|c|}{ Ensaio destrutivo } & & & \\
\hline \multicolumn{2}{|c|}{ Amostra } & $\begin{array}{c}\text { Espessura } \\
(\mu \mathrm{m})\end{array}$ & $\begin{array}{l}\text { Valor de } \\
\text { referência } \\
\text { utilizado }\end{array}$ & $\begin{array}{l}\text { Massa do } \\
\text { revestimento }\end{array}$ & $\begin{array}{l}\text { Referência } \\
\text { NBR } 5580\end{array}$ & Imersões & Resultado & \\
\hline \multirow[t]{3}{*}{21,30} & A & 92 & 56 & 750,77 & 400 & 4 & Aprovado & Aprovado \\
\hline & $\mathrm{B}$ & 65 & 56 & 490,27 & 400 & 4 & Aprovado & Aprovado \\
\hline & $\mathrm{C}$ & 67 & 56 & 569,13 & 400 & 4 & Aprovado & Aprovado \\
\hline \multirow[t]{3}{*}{60,30} & $A$ & 89 & 56 & 648,13 & 400 & 4 & Aprovado & Aprovado \\
\hline & $\mathrm{B}$ & 69 & 56 & 488,21 & 400 & 4 & Aprovado & Aprovado \\
\hline & $\mathrm{C}$ & 67 & 56 & 497,94 & 400 & 4 & Aprovado & Aprovado \\
\hline \multirow[t]{3}{*}{76,10} & $\mathrm{~A}$ & 65 & 56 & 486,67 & 400 & 4 & Aprovado & Aprovado \\
\hline & $\mathrm{B}$ & 70 & 56 & 512,63 & 400 & 4 & Aprovado & Aprovado \\
\hline & $\mathrm{C}$ & 70 & 56 & 510,44 & 400 & 4 & Aprovado & Aprovado \\
\hline \multicolumn{2}{|c|}{$\begin{array}{l}\text { Desvio } \\
\text { padrão }\end{array}$} & \multicolumn{2}{|l|}{10,31} & \multicolumn{2}{|l|}{91,76} & & & \\
\hline
\end{tabular}

Tabela 5 - Ensaios realizados com amostras do processo 2.

\begin{tabular}{|c|c|c|c|c|c|c|c|c|}
\hline & & \multicolumn{4}{|c|}{ Espessura de camada } & \multirow{2}{*}{\multicolumn{2}{|c|}{$\begin{array}{c}\text { Uniformidade da } \\
\text { camada } \\
\text { (Ensaio de Preece) }\end{array}$}} & \multirow{3}{*}{$\begin{array}{l}\text { Achatamento } \\
\text { Resultado }\end{array}$} \\
\hline & & \multicolumn{2}{|c|}{ Ensaio não destrutivo } & \multicolumn{2}{|c|}{ Ensaio destrutivo } & & & \\
\hline \multicolumn{2}{|c|}{ Amostra } & $\begin{array}{l}\text { Espessura } \\
\quad(\mu \mathrm{m})\end{array}$ & $\begin{array}{l}\text { Valor de } \\
\text { referência } \\
\text { utilizado }\end{array}$ & $\begin{array}{l}\text { Massa do } \\
\text { revestimento }\end{array}$ & $\begin{array}{l}\text { Referência } \\
\text { NBR } 5580\end{array}$ & Imersões & Resultado & \\
\hline \multirow[t]{3}{*}{21,30} & $A$ & 58 & 56 & 435,45 & 400 & 4 & Aprovado & Aprovado \\
\hline & $\mathrm{B}$ & 70 & 56 & 516,04 & 400 & 4 & Aprovado & Aprovado \\
\hline & C & 65 & 56 & 465,39 & 400 & 4 & Aprovado & Aprovado \\
\hline \multirow[t]{3}{*}{60,30} & $\mathrm{~A}$ & 69 & 56 & 509,42 & 400 & 4 & Aprovado & Aprovado \\
\hline & $\mathrm{B}$ & 65 & 56 & 464,16 & 400 & 4 & Aprovado & Aprovado \\
\hline & $\mathrm{C}$ & 65 & 56 & 481,49 & 400 & 4 & Aprovado & Aprovado \\
\hline \multirow[t]{3}{*}{76,10} & $A$ & 65 & 56 & 481,04 & 400 & 4 & Aprovado & Aprovado \\
\hline & $\mathrm{B}$ & 65 & 56 & 486,51 & 400 & 4 & Aprovado & Aprovado \\
\hline & C & 65 & 56 & 467,25 & 400 & 4 & Aprovado & Aprovado \\
\hline \multicolumn{2}{|c|}{$\begin{array}{l}\text { Desvio } \\
\text { padrão }\end{array}$} & 3,34 & & \multicolumn{2}{|l|}{24,50} & & & \\
\hline
\end{tabular}

O valor de $56 \mu \mathrm{m}$ como espessura mínima de revestimento foi adaptado, usado como referência para o resultado encontrado nos ensaios de medição de espessura 
por método não destrutivos. Para chegar em tal valor, dividiu-se $400 \mathrm{~g} / \mathrm{m}^{2}$ pela massa específica do zinco $\left(7,14 \mathrm{~g} / \mathrm{cm}^{3}\right)$, conforme orienta a ABNT NBR 6323:2016 [27].

Comparando os resultados de espessura do revestimento no processo 1 e no processo 2, pode-se observar que, para as amostras analisadas, nos corpos de prova de tubos $21,30 \mathrm{~mm}$ houve uma redução de até $15 \%$ na espessura de revestimento em $\mu \mathrm{m}$ e $21 \%$ em $\mathrm{g} / \mathrm{m}^{2}$ de massa de revestimento. Para os corpos de prova dos tubos $60,30 \mathrm{~mm}$ o processo 2 apresentou redução de $11 \%$ nos resultados de espessura de revestimento e massa de revestimento. Os corpos de prova dos tubos 76,10mm apresentaram redução de espessura de revestimento 3\% e 5\% de redução da massa de revestimento. De modo geral, podemos representar uma redução de $13 \%$ em massa de revestimento no processo 2 quando comparado ao processo 1.

Também pode-se verificar que as amostras do processo 2 apresentam uma maior uniformidade nas medições, o que indica que o processo está mais ajustado e com uma melhor repetitividade.

O desvio padrão das amostras, no que diz respeito à medição de espessura de revestimento $(\mu \mathrm{m})$, apresenta valor de 10,31 para o processo 1 e 3,34 para o processo 2. Nas medições de massa do revestimento $\left(\mathrm{g} / \mathrm{m}^{2}\right)$, o desvio padrão apresentou valores de 91,76 e 24,50 respectivamente. Isto evidencia que após as melhorias na linha de galvanização a probabilidade de ocorrer produção fora dos parâmetros desejados é menor.

No Gráfico 2 podemos acompanhar as medições de espessura de revestimento das amostras e observar que, ambas amostras estão acima do mínimo estabelecido pela norma utilizada como referência, NBR5580, porém, nas amostras do processo 1 a variação acima da referida norma foi maior. 
Gráfico 2 - Espessura do revestimento das amostras comparando com o mínimo estabelecido pela NBR5580

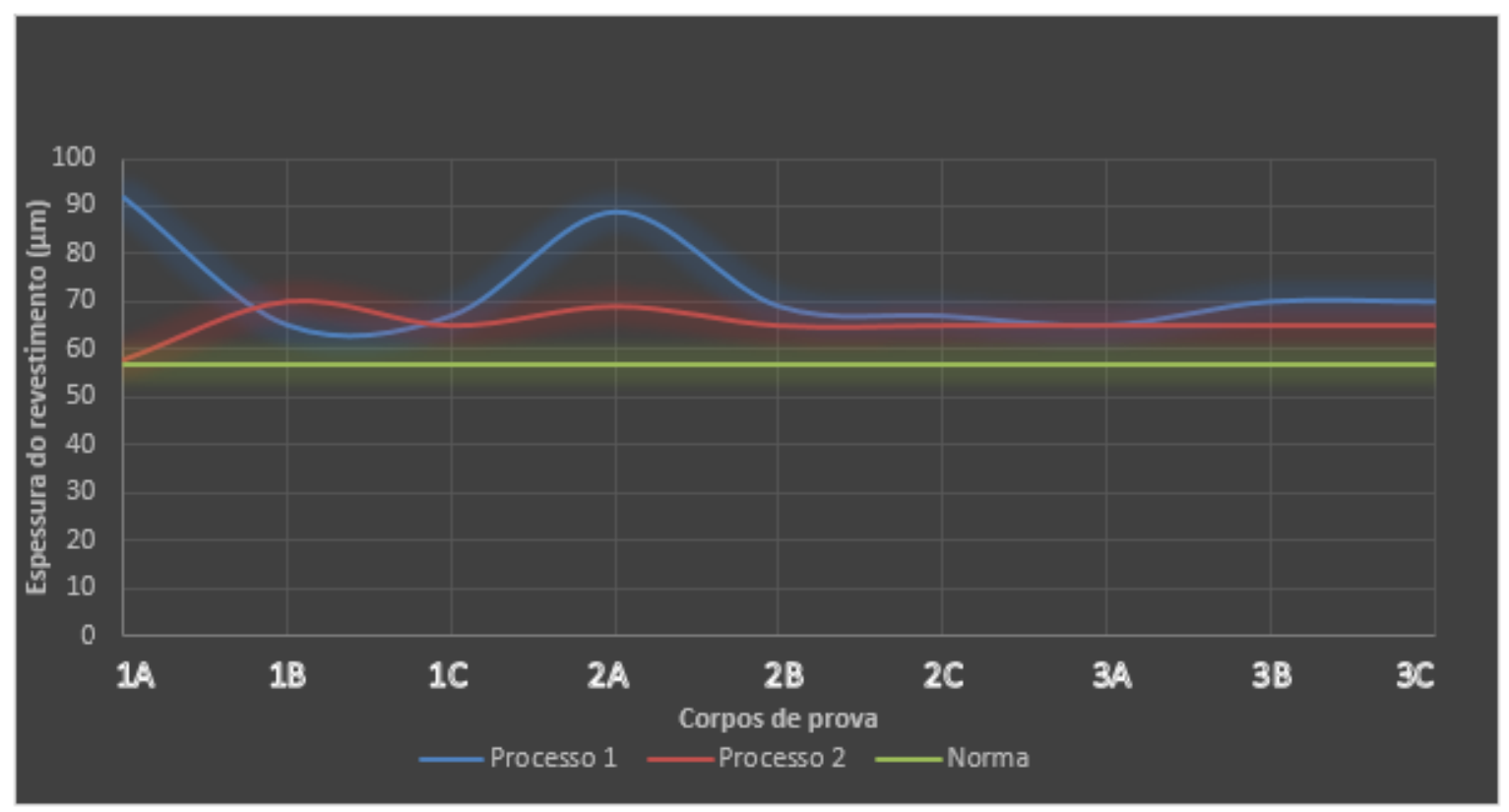

Os corpos de prova submetidos aos ensaios de achatamento e uniformidade do revestimento tiveram seus resultados aprovados para ambos os processos.

A fim de mensurar financeiramente o ganho com a redução na espessura do revestimento, calculou-se quanto de Zn seria possível economizar no processo 2 em comparação ao processo 1. Considerando que, a massa média de revestimento no processo 1 foi de $550 \mathrm{~g} / \mathrm{m}^{2}$ e no processo 2 foi de $478 \mathrm{~g} / \mathrm{m}^{2}$, teremos uma redução direta de $13 \%$ no consumo de $\mathrm{Zn}$. Isso significa que para cada tonelada de zinco utilizado para realizar os revestimentos dos tubos, haverá uma economia de $R \$$ 1.865,00 (considerando a cotação de U\$2870,00 por tonelada de zinco - 24/06/2021) [33]. 


\subsection{Análise Metalográfica para verificação das fases intermetálicas}

Para verificação das camadas intermetálicas, primeiramente foi realizado ensaio de metalografia nos corpos de prova, escolhidos aleatoriamente um corpo de prova de cada diâmetro de tubo, conforme Tabela 6 . As imagens obtidas em lente com ampliação de 50x podem ser vistas na Figura 14 a seguir.

Tabela 6 - Corpos de prova submetidos ao ensaio de MEV/EDS.

\begin{tabular}{c|c|c}
$\begin{array}{c}\text { Diâmetro } \\
\text { analisado } \\
(\mathbf{m m})\end{array}$ & Processo 1 & Processo 2 \\
\hline 21,30 & $1 \mathrm{~A}$ & $1 \mathrm{~A}$ \\
\hline 60,30 & $2 \mathrm{~B}$ & $2 \mathrm{~A}$ \\
\hline 76,10 & $3 \mathrm{~A}$ & $3 \mathrm{C}$
\end{tabular}


Figura 14 - Imagens obtidas no ensaio de metalografia
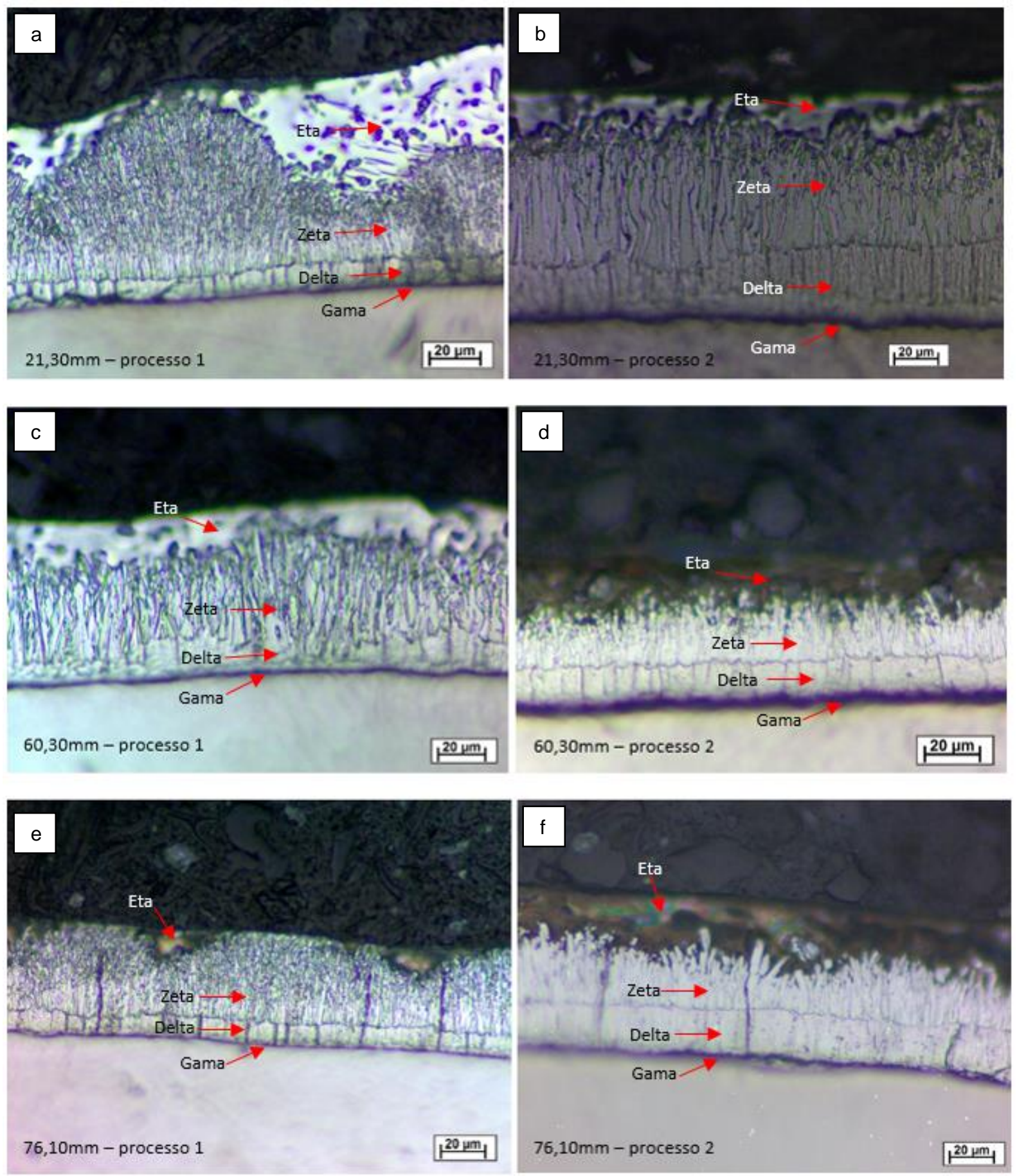

a) amostra 21,30 $\mathrm{mm}$ - processo 1; b) amostra 21,30mm - processo 2; c) amostra 60,30mm - processo 1; d) amostra 60,30mm - processo 2; e) amostra 76,10mm - processo 1; f) amostra 76,10mm processo 2. 
Com as imagens obtidas com auxílio de microscópio ótico não foi possível realizar a caracterização das fases intermetálicas de maneira clara, mais especificamente no que diz respeito à última camada de revestimento, a camada eta

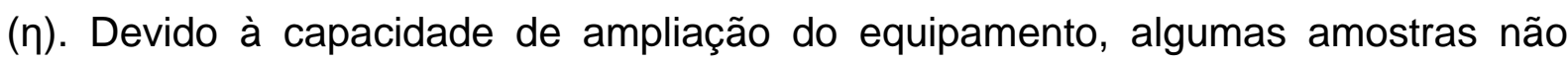
tiveram uma captura de imagem nítida, a camada de eta, zinco puro, é muito macia e pode ter sido removida em excesso durante o polimento, gerando uma diferença de nível em relação às demais fases. Para uma análise mais precisa das fases intermetálicas do revestimento, os corpos de prova foram analisados em MEV/EDS com caracterização dos elementos químicos Ferro e Zinco presentes em cada fase.

Nas figuras 15 a 20 a seguir, é possível observar as imagens obtidas e composição química analisada nas fases intermetálicas e nos gráficos 3 a 26 é possível observar o percentual em massa de ferro e zinco encontrados em cada fase intermetálica analisada. 
Figura 15 - Imagem da amostra 1A, diâmetro 21,30mm referente ao Processo 1

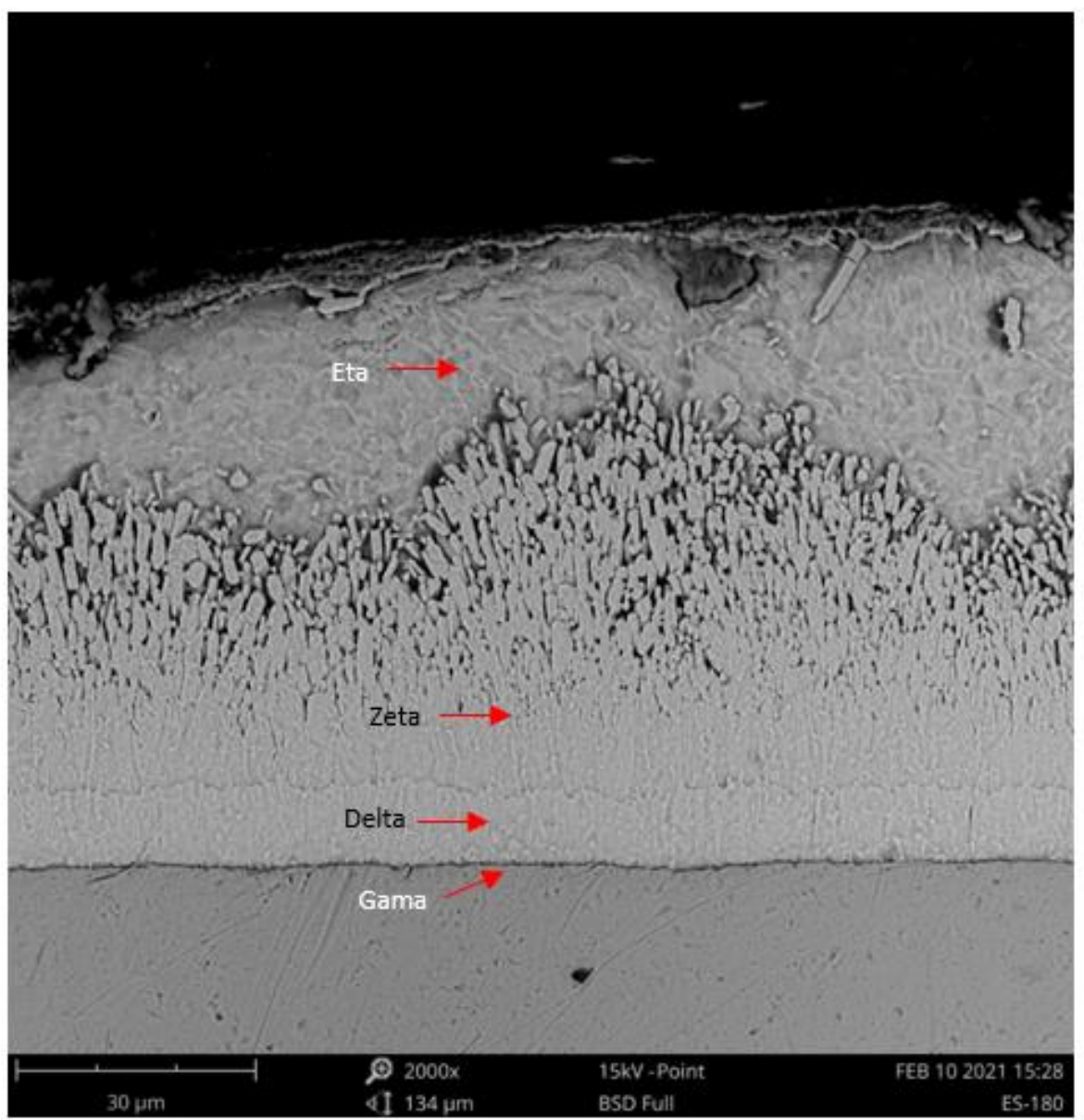

Gráficos 3, 4, 5 e 6 - Análise de EDS da composição em massa (\%) de Fe e Zn nas fases intermetálicas, amostra 1 A P1.

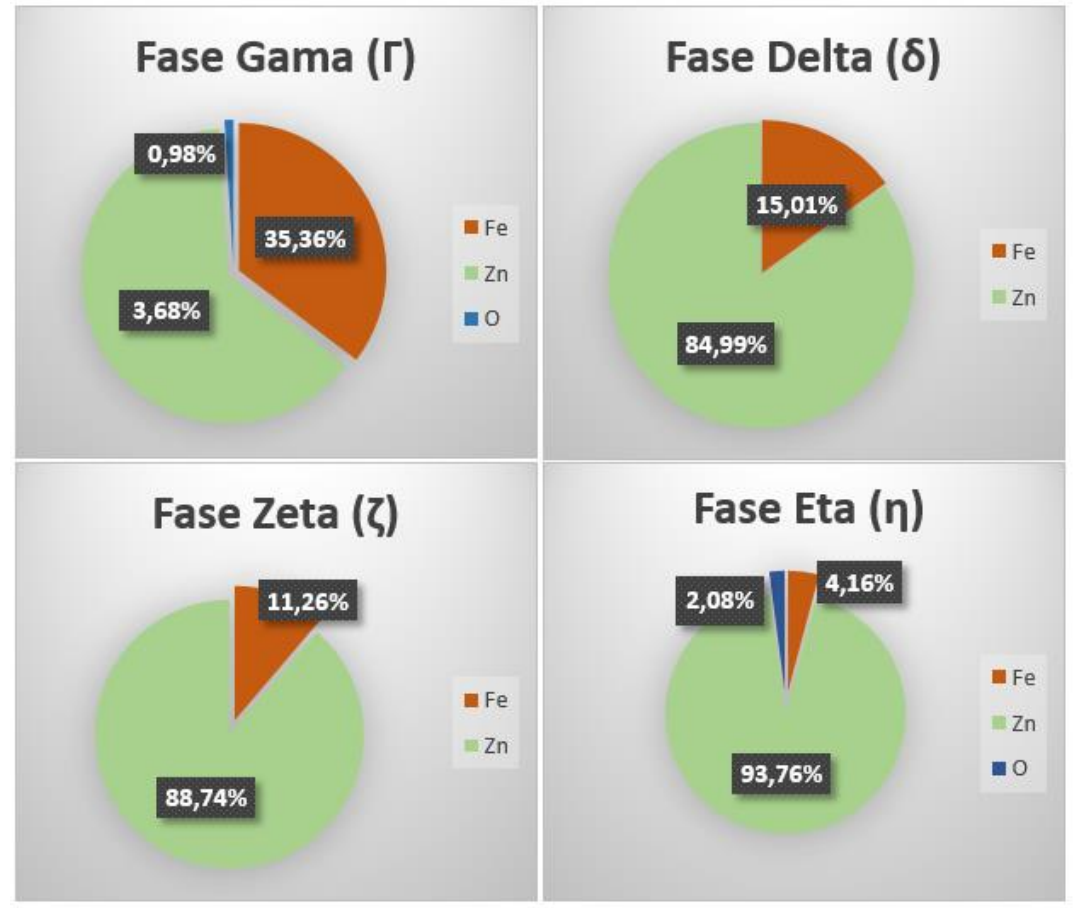


Figura 16 - Imagem da amostra 1A, diâmetro 21,30mm referente ao Processo 2

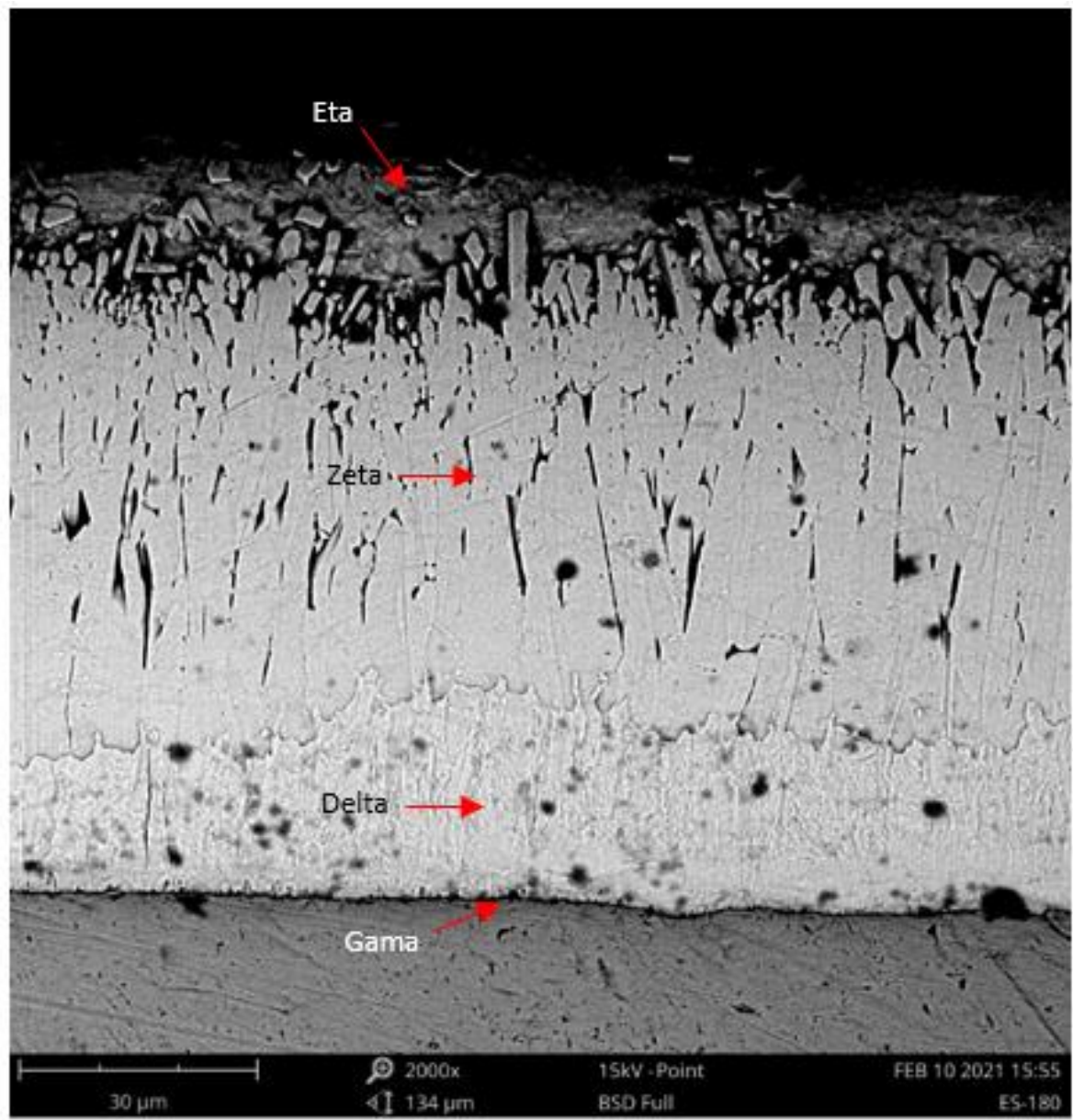

Gráficos 7, 8, 9 e 10 - Análise de EDS da Composição em massa (\%) de Fe e Zn nas fases intermetálicas, amostra 1A P2.

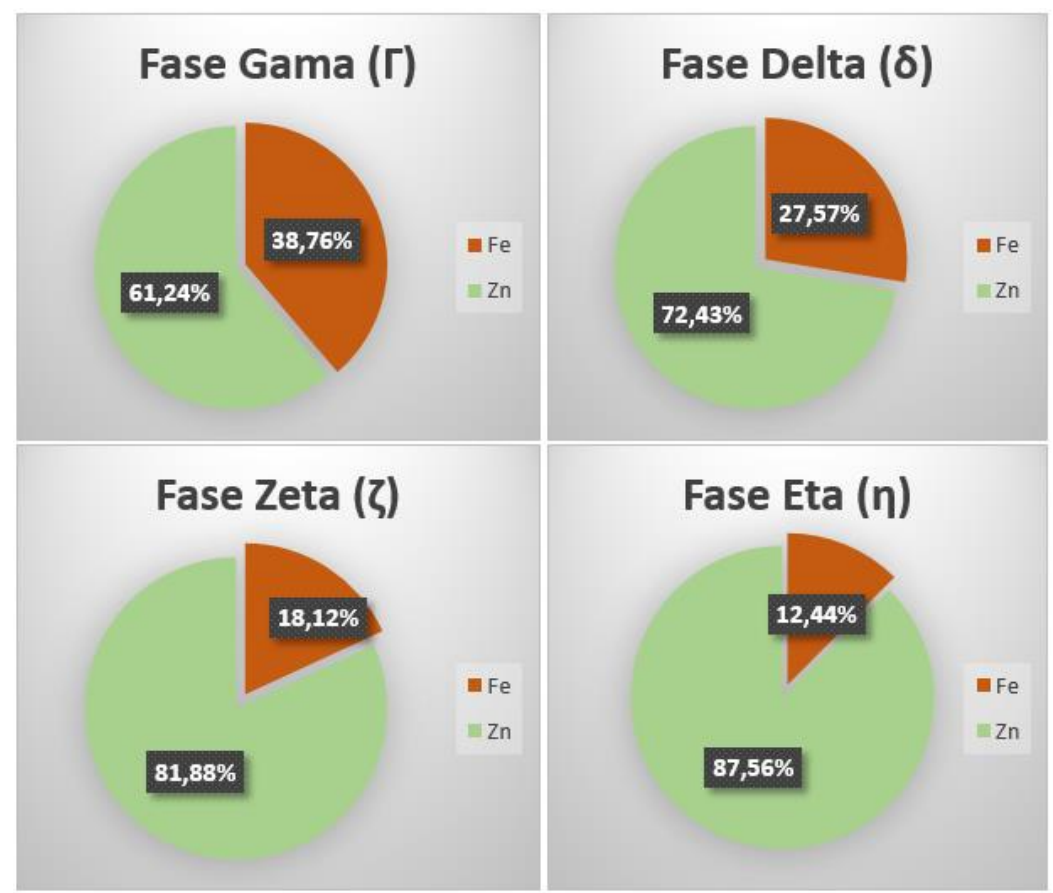


Figura 17 - Imagem da amostra 2B, diâmetro 60,30mm referente ao Processo 1

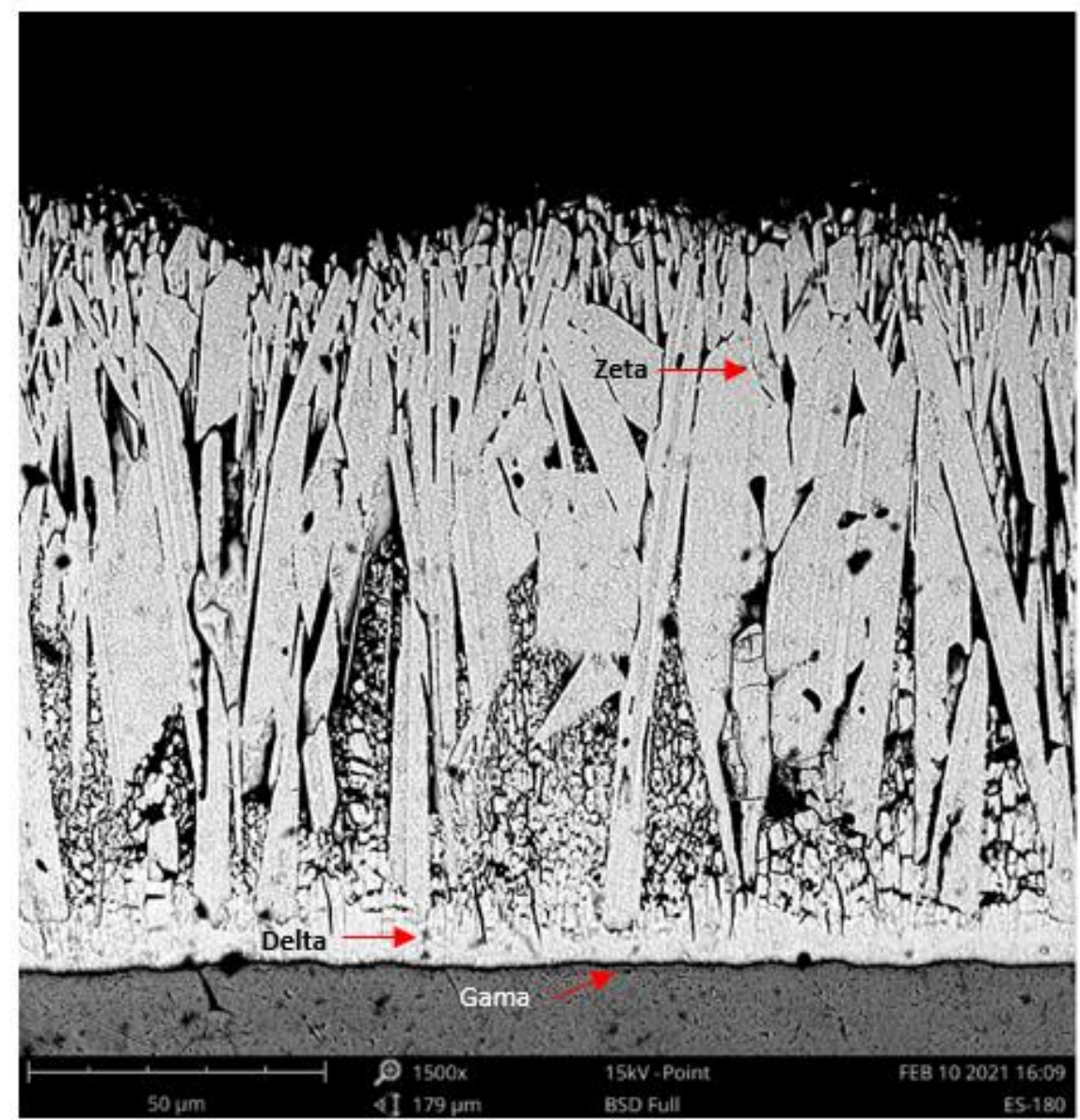

Gráficos 11, 12, 13 e 14 - Análise de EDS da Composição em massa (\%) de Fe e Zn nas fases intermetálicas, amostra 2B P1

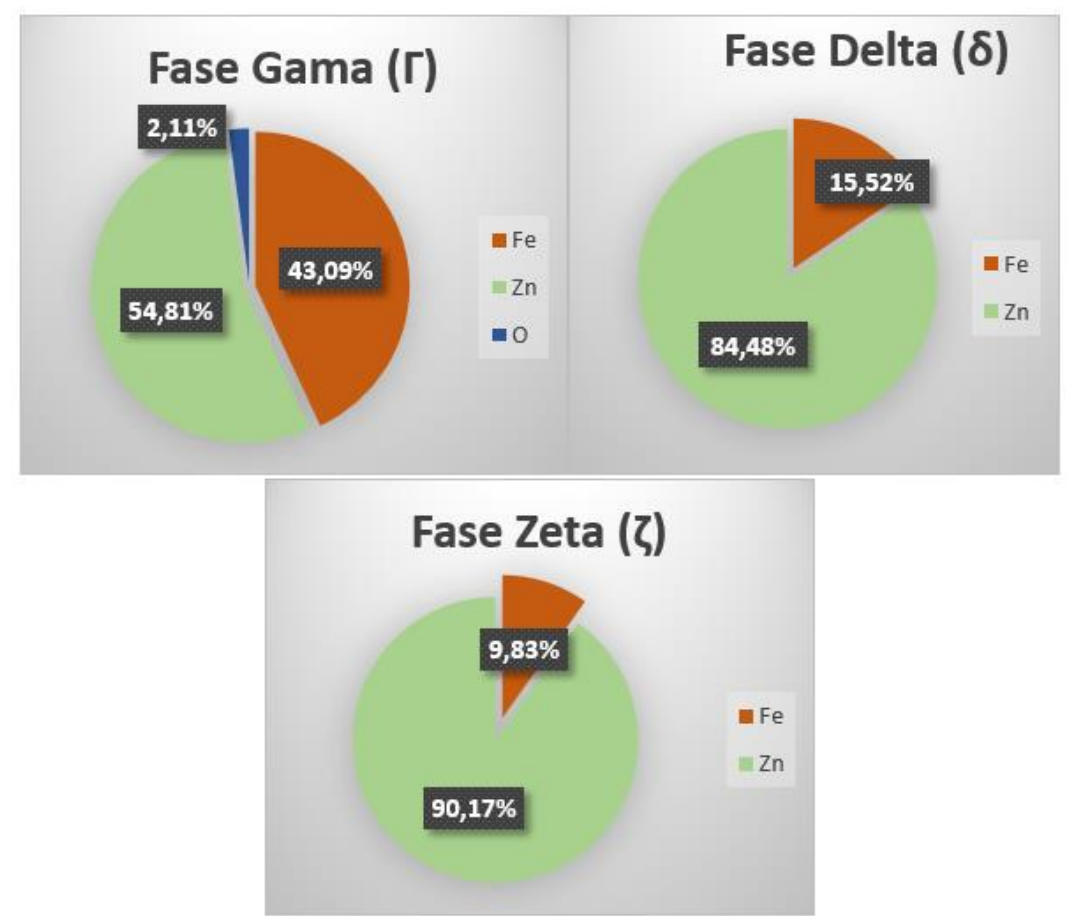


Figura 18 - Imagem da mostra 2A, diâmetro 60,30mm referente ao Processo 2

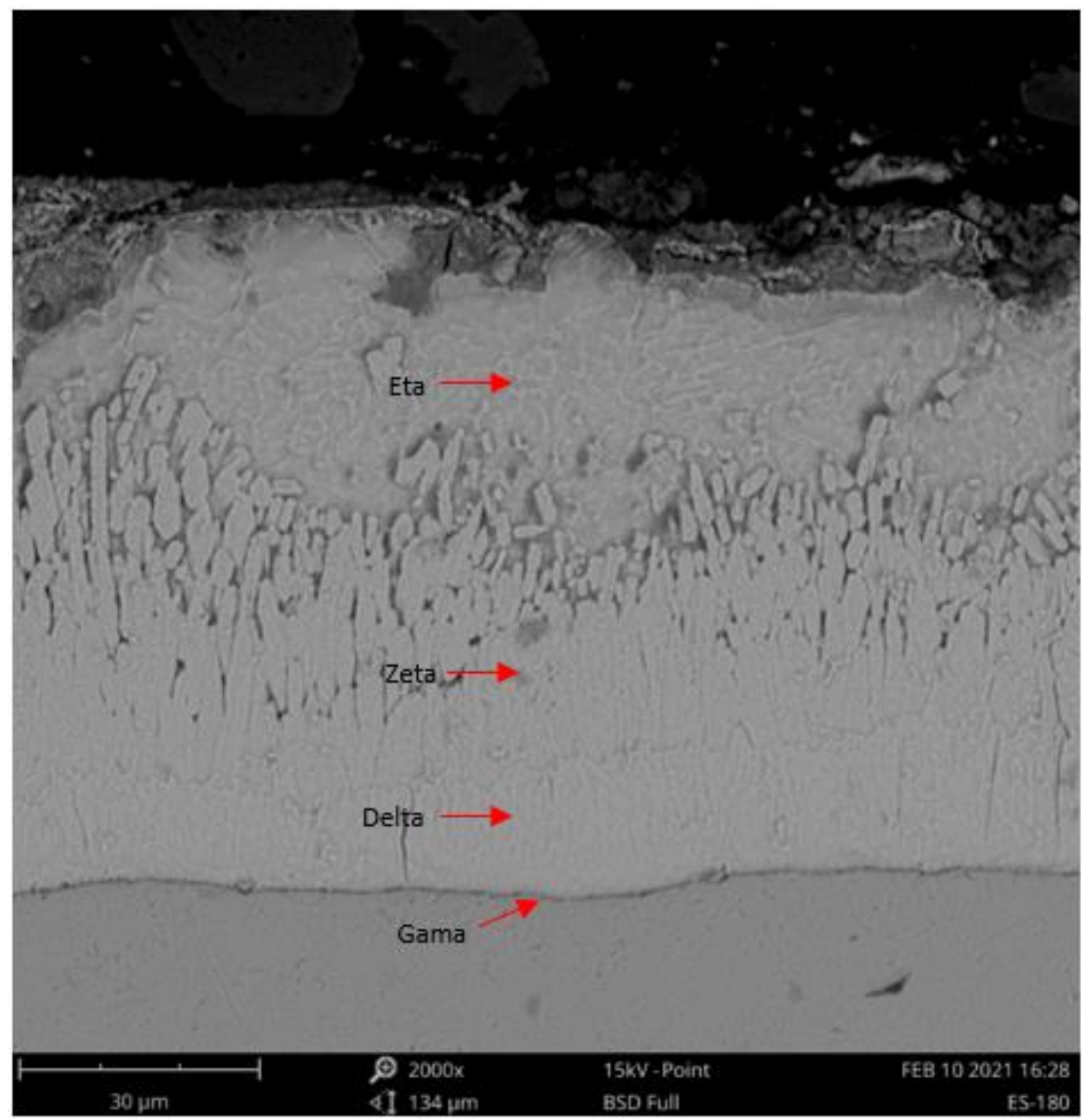

Gráficos 15, 16, 17 e 18 - Análise de EDS da composição em massa (\%) de Fe e Zn nas fases intermetálicas, amostra 2A P2

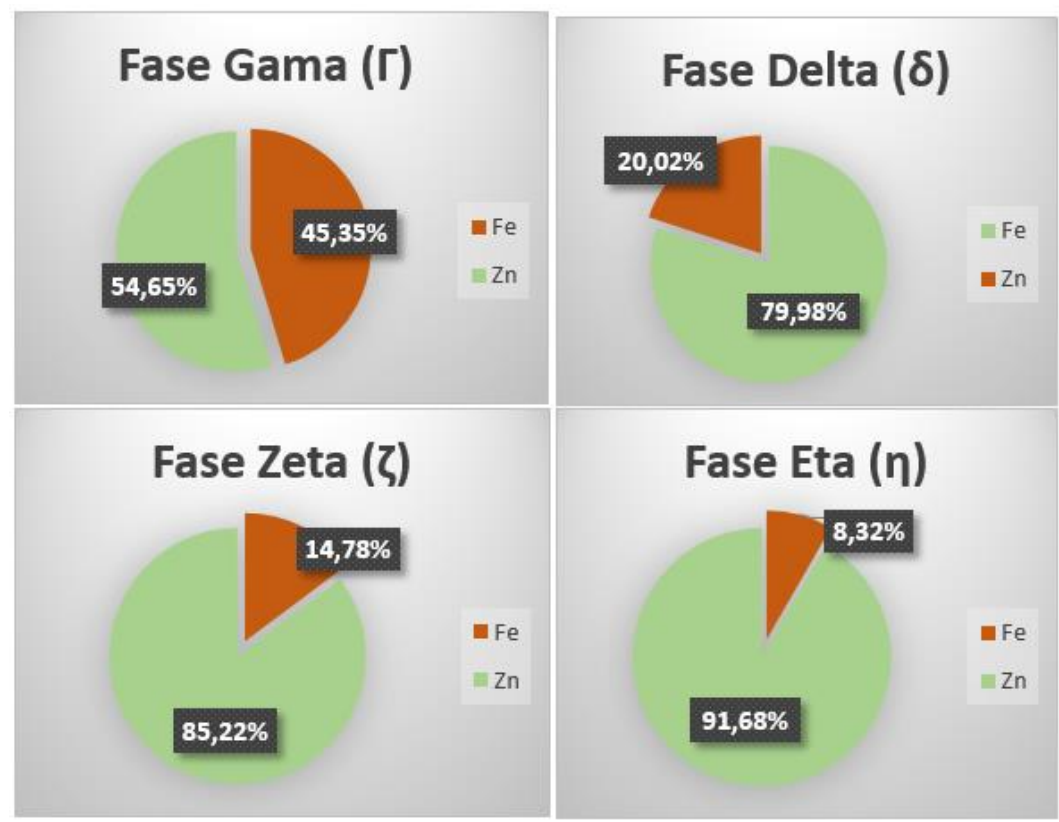


Figura 19 - Imagem da amostra 3A, diâmetro 76,10mm referente ao Processo 1

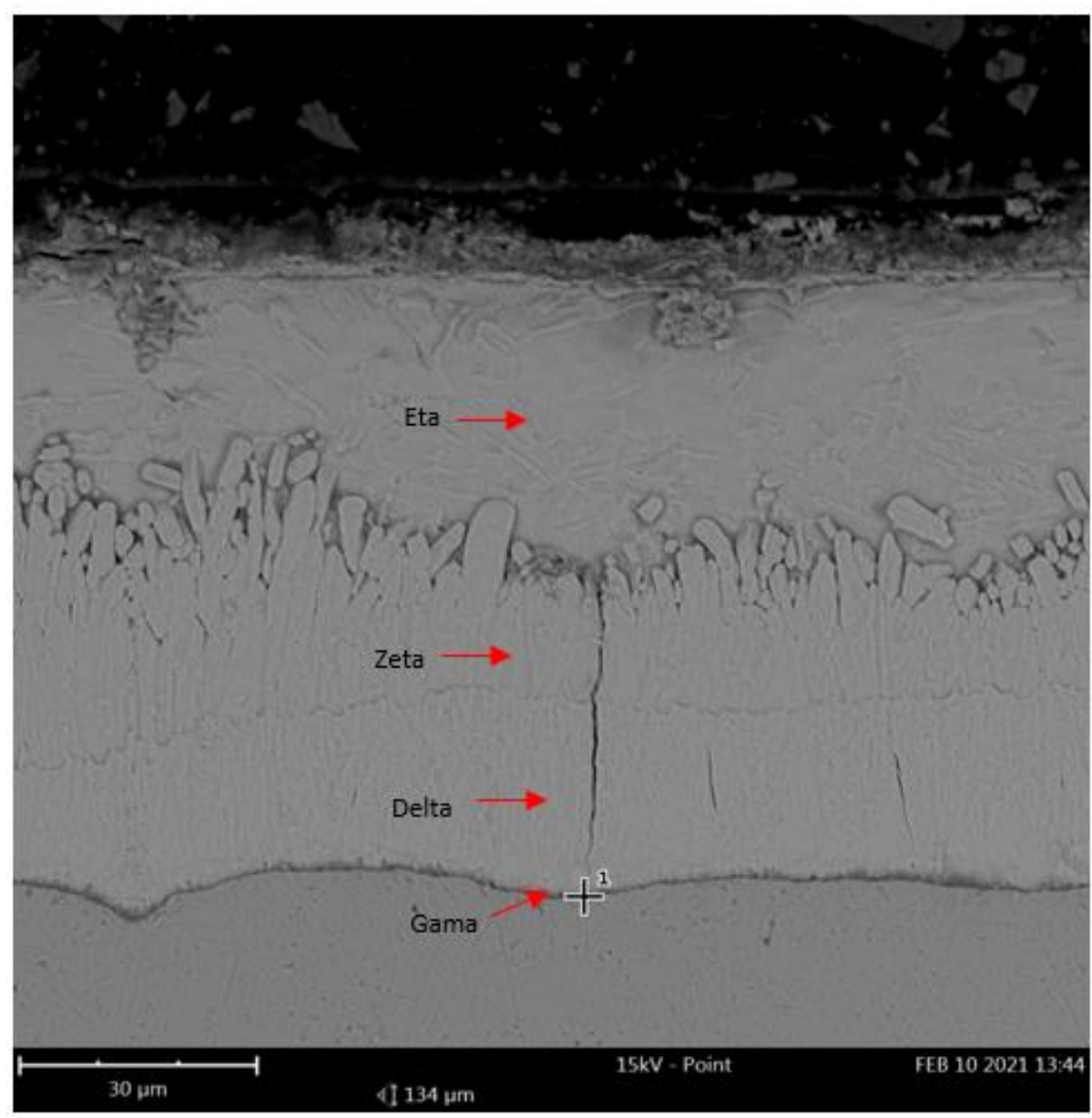

Gráficos 19, 20, 21 e 22 - Análise de EDS da composição em massa (\%) de Fe e Zn nas fases intermetálicas, amostra 3A P1.

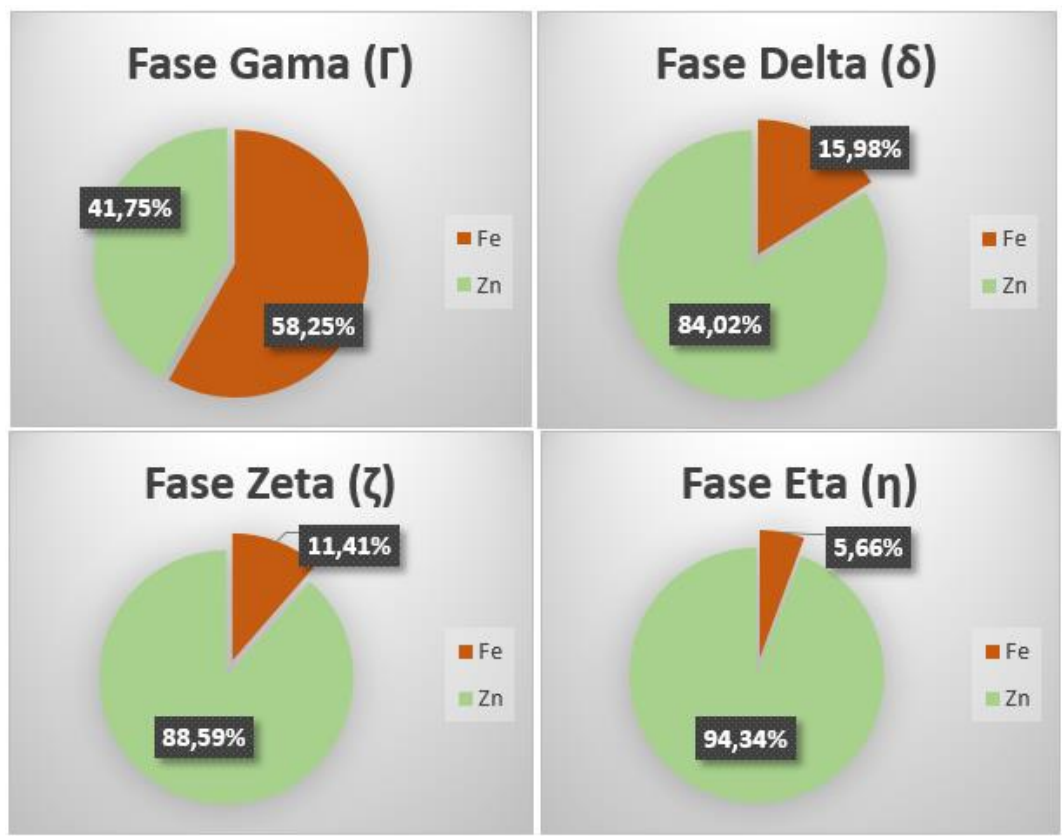


Figura 20 - Imagem da amostra 3C, diâmetro 76,10mm referente ao Processo 2

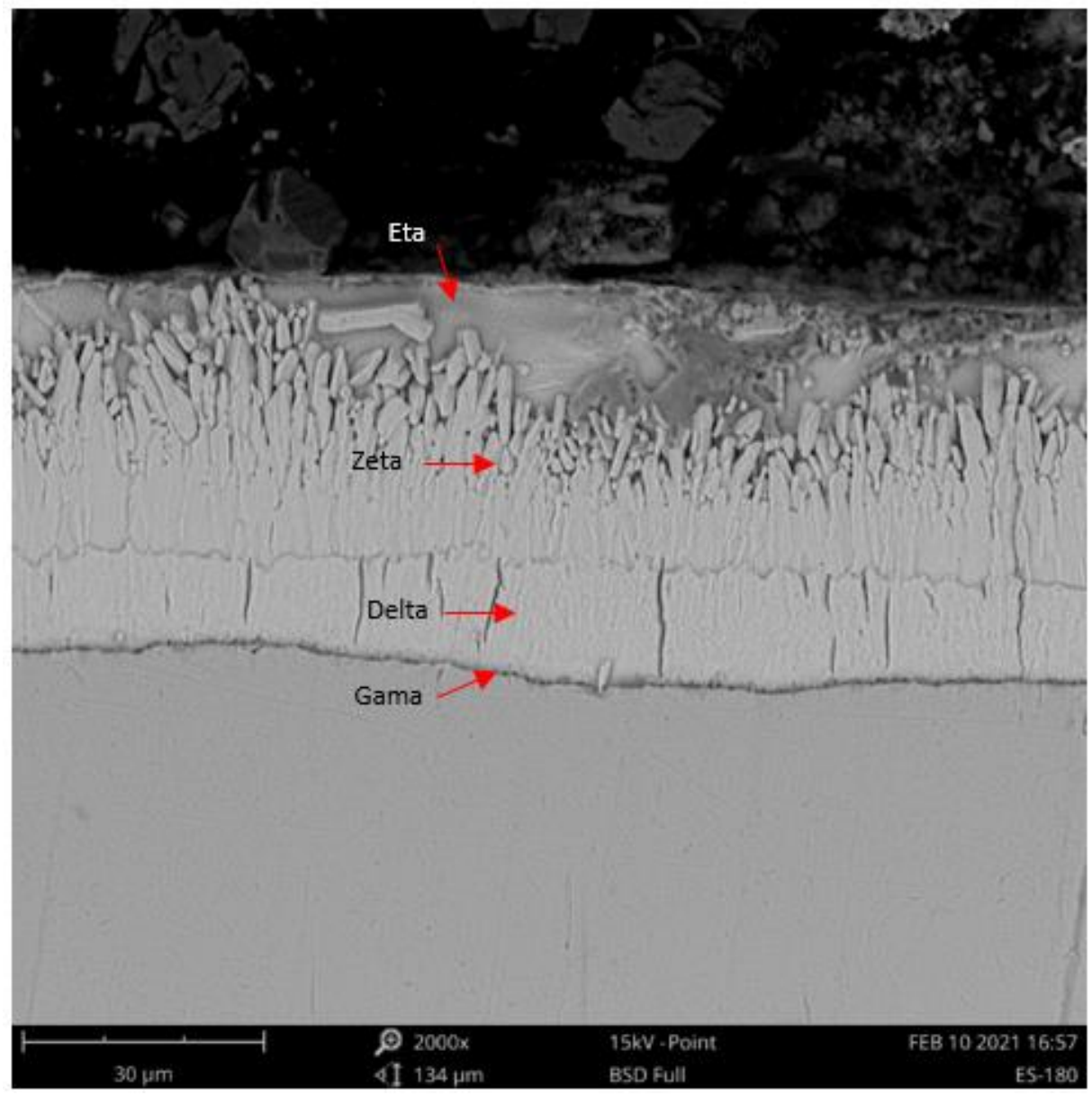

Gráficos 23, 24, 25 e 26 - Análise de EDS da composição em massa (\%) de Fe e Zn nas fases intermetálicas, amostra 3C P2.

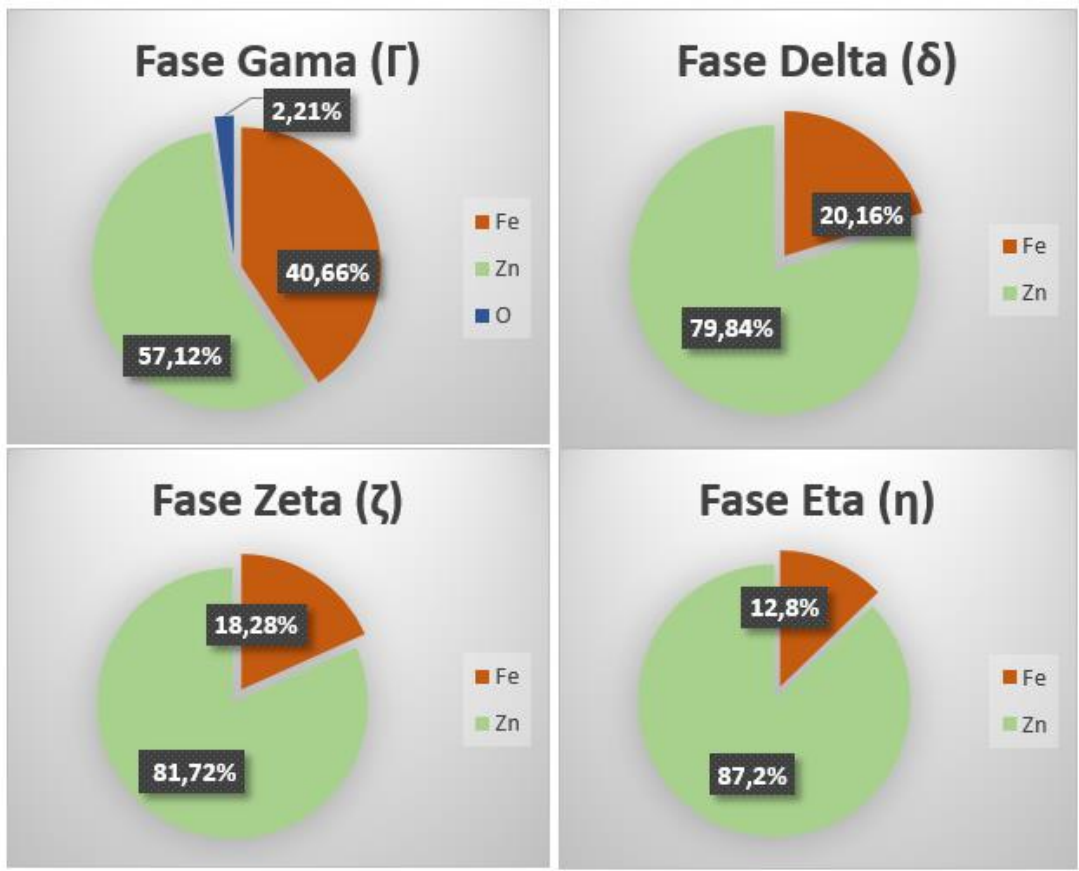


As imagens obtidas com MEV ficaram mais nítidas e foi possível observar os diferentes crescimentos de camadas e suas estruturas nas fases intermetálicas.

Nas imagens obtidas da amostras do processo 2, foi possível visualizar um crescimento de camada mais regular na camada de fase zeta, evidenciando que, com controle exato do tempo de imersão da peça no banho de zinco e posterior resfriamento da peça, é possível controlar o crescimento de camada das fases intermetálicas.

As análises de EDS caracterizaram as camadas intermetálicas do revestimento nas amostras analisadas, identificando o percentual em masssa de ferro e zinco presentes. Para análise dos resultados, comparou-se os valores obtidos com os valores esperados, consultando a bibliografia (Quadro 1).

Quadro 1 - Composição de Fe e Zn nas fases intermetálicas do revestimento analisadas, comparando com a literatura.

\begin{tabular}{|c|c|c|c|c|c|c|c|c|c|}
\hline \multirow{2}{*}{$\begin{array}{c}\text { Fases } \\
\text { Intermetálicas }\end{array}$} & \multicolumn{2}{|c|}{ Eta } & \multicolumn{2}{c|}{ Zeta } & \multicolumn{2}{c|}{ Delta } & \multicolumn{2}{c|}{ Gamma } \\
\cline { 2 - 10 } & $\mathrm{Fe}(\%)$ & $\mathrm{Zn}(\%)$ & $\mathrm{Fe}(\%)$ & $\mathrm{Zn}(\%)$ & $\mathrm{Fe}(\%)$ & $\mathrm{Zn} \mathrm{( \% )}$ & $\mathrm{Fe}(\%)$ & $\mathrm{Zn}(\%)$ \\
\hline \multicolumn{2}{|c|}{ Literatura (25) } & 0 & 100 & $5-6$ & $94-95$ & $7-11,5$ & $88,5-93$ & $23,5-28$ & $72-76,5$ \\
\hline \multirow{2}{*}{$\begin{array}{c}\text { Processo } \\
1\end{array}$} & 1A & 4,16 & 93,76 & 11,26 & 88,74 & 15,01 & 84,99 & 35,36 & 63,68 \\
\cline { 2 - 10 } & 2B & - & - & 9,83 & 90,17 & 15,52 & 84,48 & 43,08 & 54,81 \\
\cline { 2 - 10 } & $3 \mathrm{~A}$ & 5,66 & 94,34 & 11,41 & 88,59 & 15,98 & 84,02 & 58,25 & 41,75 \\
\hline \multirow{2}{*}{$\begin{array}{c}\text { Processo } \\
2\end{array}$} & $1 \mathrm{~A}$ & 12,44 & 87,56 & 18,12 & 81,88 & 27,57 & 72,43 & 38,76 & 61,24 \\
\cline { 2 - 10 } & 2A & 8,32 & 91,68 & 14,78 & 85,22 & 20,02 & 79,98 & 45,35 & 54,65 \\
\cline { 2 - 9 } & $3 \mathrm{C}$ & 12,8 & 87,2 & 18,28 & 81,72 & 20,16 & 79,84 & 40,66 & 57,12 \\
\hline
\end{tabular}

Comparando os resultados das camadas intermetálicas, de um modo geral, o resultado da composição em massa de Fe encontrada nas fases intermetálicas das amostras foram mais elevados do que trata a bibliografia, variando em torno de 5 a $10 \%$, exceto as fases gama, que apresentou variações de até $20 \%$ e a fase eta que apresentou $\mathrm{Fe}$ em todas as amostras. Uma hipótese para os altos valores de $\mathrm{Fe}$ encontrados nas fases intermetálicas é a contaminação das amostras na etapa de preparação da peça, mais especificamente na etapa de corte de amostra para embutimento. $O$ corte foi realizado em serrinha manual de aço, o que pode ter agregado particulas à amostra cortada devido ao zinco ser mais macio que o aço e também pelo lixamento excessivo das peças que pode ter arrastado essas partículas. 
Em algumas amostras foram encontrados baixos percentuais de oxigênio, que pode ser relacionado ao início da oxidação do corpo de prova após a sua preparação.

No corpo de prova $2 \mathrm{~A}$ do processo 1 , não foi oberservada a camada de fase eta, pois a fase zeta teve maior crescimento, aflorando até a superfície do revestimento. Uma possível explicação para esse crecimento exagerado da camada de fase zeta é o tempo demasiado da peça em imersão ao banho de zinco, que pode ser relacionado com a falta do controle exato do tempo de imersão das peças.

As espessuras e as camadas de liga podem variar fortemente em função das condições de galvanização e do material a ser galvanizado, como temperatura do banho, rugosidade da superfície, composição do aço, teor de alumínio no zinco, etc. [3]. Em relação à morfologia, todas as amostras analisadas tiveram o resultado esperado nas camadas intermetálicas, sendo a fase gama como uma fina camada, quase imperceptível, fase delta e zeta com crescimentos colunares.

\subsection{Ensaio de névoa salina}

A fim de avaliar a resistência à corrosão, os corpos de prova foram submetidos ao ensaio de corrosão acelerada em câmara de névoa salina. Três corpos de prova de cada diâmetro de tubo do processo 1 e do processo 2 foram colocados ao mesmo momento em câmara de névoa salina e foram acompanhados diariamente desde os primeiros pontos de corrosão até a corrosão generalizada das peças.

Os corpos de prova permaneceram em névoa salina de 07/05/2019 a 03/07/2019, totalizando 1392 horas de ensaio, até atingir o grau máximo de corrosão.

No Quadro 2 é possível acompanhar o resultado e evolução dos graus de corrosão nos corpos de prova.

No Gráfico 27 é possível visualizar a ilustração da evolução da corrosão vermelha nos corpos de prova do processo 1 e processo 2, nos graus de V0 (0) a V5 (5) nos tempos de 336 a 1392 horas de ensaio, conforme ABNT NBR 8093:1983 
Quadro 2 - Relatório de acompanhamento da evolução da corrosão nos corpos de prova submetidos ao ensaio de névoa salina.

\begin{tabular}{|c|c|c|c|c|c|c|c|c|c|c|c|c|c|c|c|c|c|c|c|c|c|c|c|c|c|c|}
\hline & \multirow{4}{*}{$\begin{array}{c}\text { DATA } \\
\text { HORAS TESTE }\end{array}$} & \multicolumn{24}{|c|}{ ASPECTO/GRAU DE CORROSÃO } \\
\hline & & & \multirow{2}{*}{\multicolumn{2}{|c|}{$\frac{07 / \mathrm{mai}}{24 \mathrm{~h}}$}} & \multirow{2}{*}{\multicolumn{2}{|c|}{$\frac{08 / \mathrm{mai}}{48 \mathrm{~h}}$}} & \multirow{2}{*}{\multicolumn{2}{|c|}{ 09/mai }} & \multicolumn{2}{|c|}{$10 / \mathrm{mai}$} & \multirow{2}{*}{\multicolumn{2}{|c|}{$\begin{array}{c}13 / \mathrm{mai} \\
168 \mathrm{~h}\end{array}$}} & \multirow{2}{*}{\multicolumn{2}{|c|}{$\frac{14 / \mathrm{mai}}{192 \mathrm{~h}}$}} & & & $22 /$ & & $06 /$ & & $13 /$ & & & & 03 & \\
\hline & & & & & & & & & & & & & & & \multicolumn{2}{|c|}{$336 \mathrm{~h}$} & \multicolumn{2}{|c|}{$384 \mathrm{~h}$} & \multicolumn{2}{|c|}{$744 \mathrm{~h}$} & \multicolumn{2}{|c|}{$912 \mathrm{~h}$} & \multicolumn{2}{|c|}{$1176 \mathrm{~h}$} & \multicolumn{2}{|c|}{$1392 \mathrm{~h}$} \\
\hline & & & $\mathbf{v}$ & B & $\mathbf{v}$ & B & $\mathbf{v}$ & B & $\mathbf{v}$ & B & $\mathbf{v}$ & B & $\mathbf{v}$ & B & $\mathbf{v}$ & B & $\mathbf{v}$ & B & $\mathbf{v}$ & B & $\mathbf{v}$ & B & $\mathbf{v}$ & B & $\mathbf{v}$ & B \\
\hline \multirow{18}{*}{ 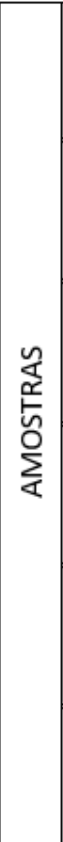 } & \multirow{3}{*}{2} & $1 \mathrm{~A}$ & Vo & B3 & Vo & B3 & Vo & B4 & Vo & B4 & V0 & $\mathrm{B} 5$ & V0 & $\mathrm{B} 5$ & V3 & $\mathrm{B} 5$ & V3 & B5 & V3 & B5 & V3 & $\mathrm{B} 5$ & V4 & $\mathrm{B} 5$ & V5 & $\mathrm{B} 5$ \\
\hline & & 1B & vo & B3 & vo & B3 & vo & B4 & vo & B4 & vo & B5 & vo & B5 & V1 & B5 & V3 & B5 & V3 & B5 & V3 & B5 & V4 & B5 & V4 & B5 \\
\hline & & 1C & vo & B3 & vo & B3 & vo & B4 & vo & B4 & vo & B5 & vo & B5 & V1 & B5 & V3 & B5 & V3 & B5 & V3 & B5 & V4 & B5 & V4 & B5 \\
\hline & \multirow{3}{*}{ న } & $1 \mathrm{~A}$ & V0 & B4 & V0 & B4 & V0 & B4 & V0 & B4 & V0 & B5 & V0 & B5 & V3 & B5 & V3 & B5 & V4 & B5 & V4 & B5 & V4 & B5 & V4 & B5 \\
\hline & & $1 \mathrm{~B}$ & vo & B4 & Vo & B4 & vo & B4 & vo & B4 & vo & B5 & vo & B5 & V3 & B5 & V3 & B5 & V4 & B5 & V4 & B5 & V4 & B5 & V4 & B5 \\
\hline & & $1 \mathrm{C}$ & V0 & B4 & Vo & B4 & Vo & B4 & Vo & B4 & vo & B5 & vo & B5 & V3 & B5 & V3 & B5 & V4 & B5 & V4 & B5 & V4 & B5 & V5 & B5 \\
\hline & \multirow{3}{*}{$\vec{\alpha}$} & $2 A$ & V0 & B3 & Vo & B3 & Vo & B3 & Vo & B3 & Vo & B4 & V0 & B5 & V3 & $\mathrm{B} 5$ & V3 & B5 & V3 & B5 & V3 & B5 & V4 & B5 & V5 & B5 \\
\hline & & $2 B$ & vo & B3 & vo & B3 & vo & B3 & vo & B3 & vo & B4 & vo & B5 & V3 & B5 & V3 & B5 & V3 & B5 & V3 & B5 & V4 & B5 & V5 & B5 \\
\hline & & $2 \mathrm{C}$ & Vo & B4 & Vo & B4 & Vo & B4 & Vo & B4 & vo & B4 & vo & B5 & V3 & B5 & V3 & B5 & V3 & B5 & V3 & B5 & V4 & B5 & V5 & B5 \\
\hline & \multirow{3}{*}{ న } & $2 \mathrm{~A}$ & V0 & B4 & V0 & B4 & V0 & B4 & V0 & B4 & V0 & B4 & V0 & B5 & V3 & B5 & V4 & B5 & V4 & B5 & V4 & B5 & V5 & B5 & V5 & B5 \\
\hline & & $2 B$ & vo & B4 & Vo & B4 & vo & B4 & vo & B4 & vo & B4 & vo & B5 & V3 & B5 & V4 & B5 & V4 & B5 & V4 & B5 & V5 & B5 & V5 & B5 \\
\hline & & $2 C$ & vo & B4 & vo & B4 & vo & B4 & vo & B4 & vo & B4 & vo & B5 & V3 & B5 & V4 & B5 & V4 & B5 & V4 & B5 & V5 & B5 & V5 & B5 \\
\hline & \multirow{3}{*}{$a$} & $3 A$ & Vo & B3 & V0 & B3 & Vo & B3 & Vo & B3 & Vo & B5 & V0 & B5 & V3 & B5 & V4 & B5 & V5 & B5 & V5 & B5 & V5 & B5 & V5 & B5 \\
\hline & & 3B & vo & B3 & Vo & B3 & Vo & B3 & vo & B3 & vo & B5 & vo & B5 & V3 & B5 & V4 & B5 & V5 & B5 & V5 & B5 & V5 & B5 & V5 & B5 \\
\hline & & $3 C$ & vo & B3 & Vo & B3 & Vo & B3 & vo & B3 & vo & B5 & vo & B5 & V3 & B5 & V4 & B5 & V5 & B5 & V5 & B5 & V5 & B5 & V5 & B5 \\
\hline & \multirow{3}{*}{ ล } & $3 A$ & V0 & B4 & V0 & B4 & V0 & B4 & V0 & B4 & V0 & B5 & V0 & B5 & V3 & B5 & V4 & B5 & V5 & B5 & V5 & B5 & V5 & B5 & V5 & B5 \\
\hline & & 3B & vo & B4 & Vo & B4 & vo & B4 & vo & B4 & vo & B5 & vo & B5 & V3 & B5 & V4 & B5 & V5 & B5 & V5 & B5 & V5 & B5 & V5 & B5 \\
\hline & & $3 C$ & vo & B4 & Vo & B4 & vo & B4 & vo & B4 & vo & B5 & vo & B5 & V3 & B5 & V4 & B5 & V5 & B5 & V5 & B5 & V5 & B5 & V5 & B5 \\
\hline & & & B & & & & & & & & & & & & $\begin{array}{l}2 \\
3\end{array}$ & & & & & & 5 & & & & & \\
\hline
\end{tabular}


Gráfico 27 - Evolução da corrosão vermelha nos corpos de prova de 336 horas a 1392 horas de ensaio.

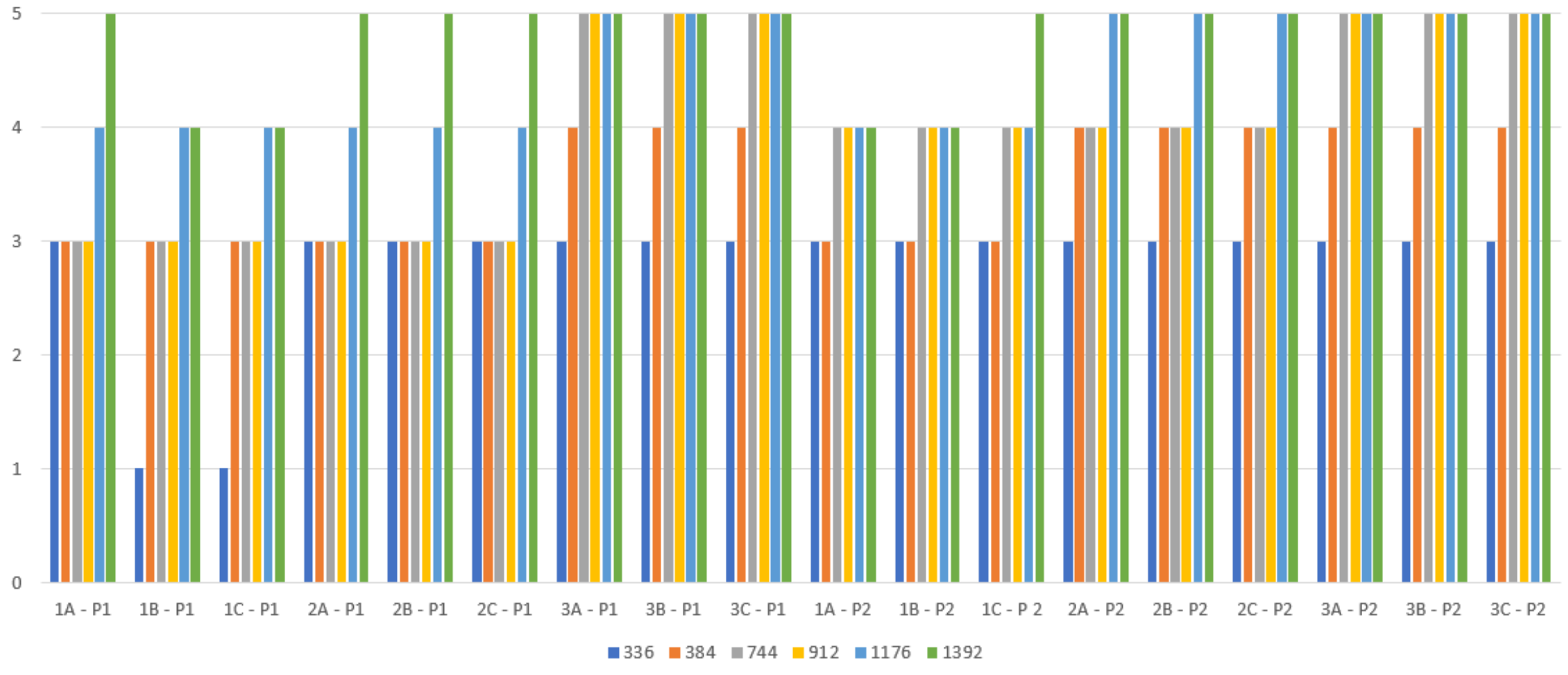


Para representação deste ensaio foram escolhidas imagens dos corpos de prova após 24 horas (início do ensaio e corrosão branca detectada), 336 horas (tempo em que é possível observar o início da corrosão vermelha nos corpos de prova) e 1392 horas (tempo em que foi detectado a corrosão generalizada nos corpos de prova.

Nas Figuras 21 a 23 a seguir, é possível observar a evolução da corrosão nos corpos de provas submetidas a 24 horas de ensaio em névoa salina.

Figura 21 - 24 horas de ensaio em corpos de prova diâmetro $21,30 \mathrm{~mm}$ - processo 1 e processo 2

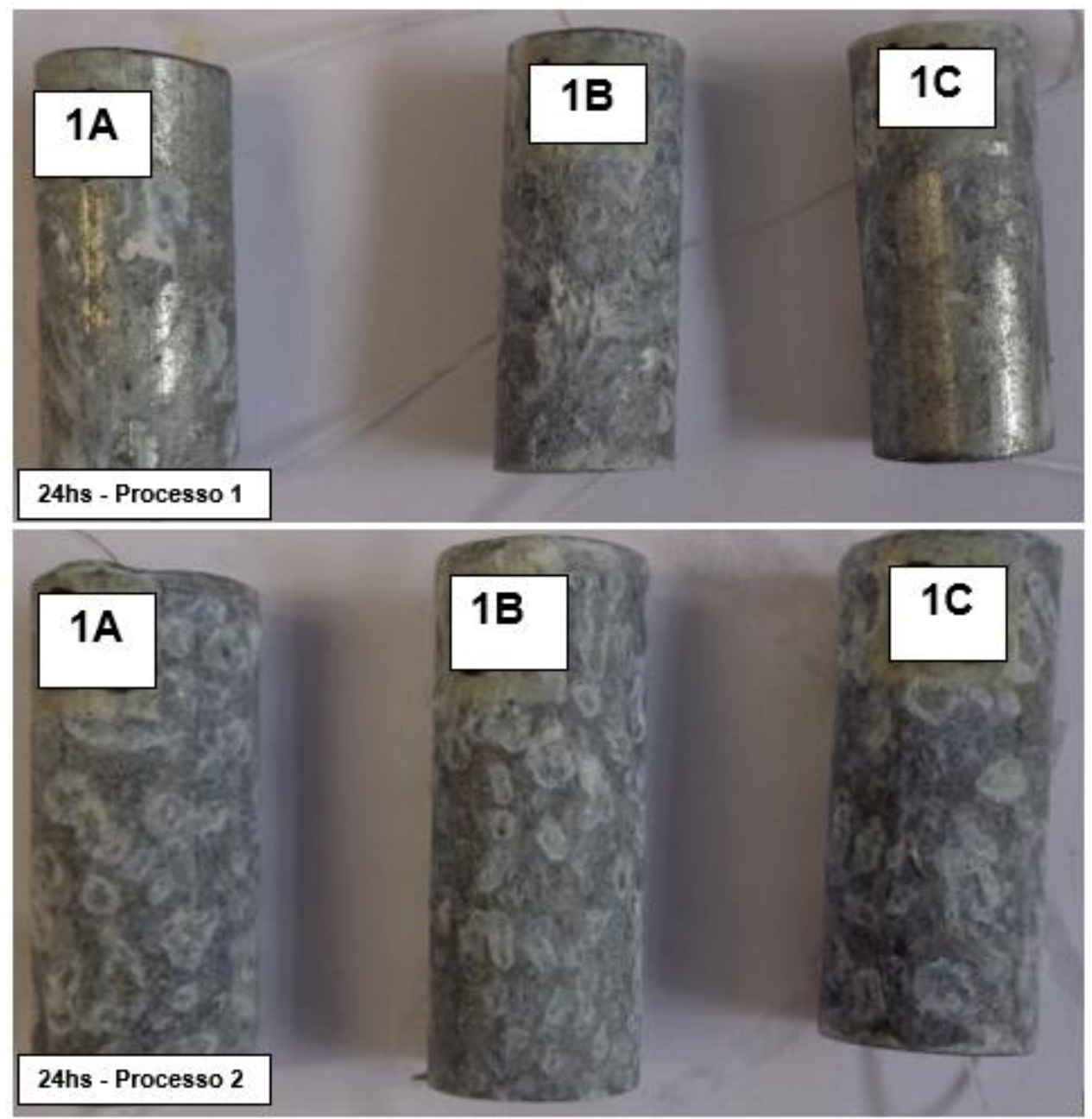


Figura 22 - 24 horas de ensaio em corpos de prova diâmetro 60,30mm - processo 1 e processo 2 .

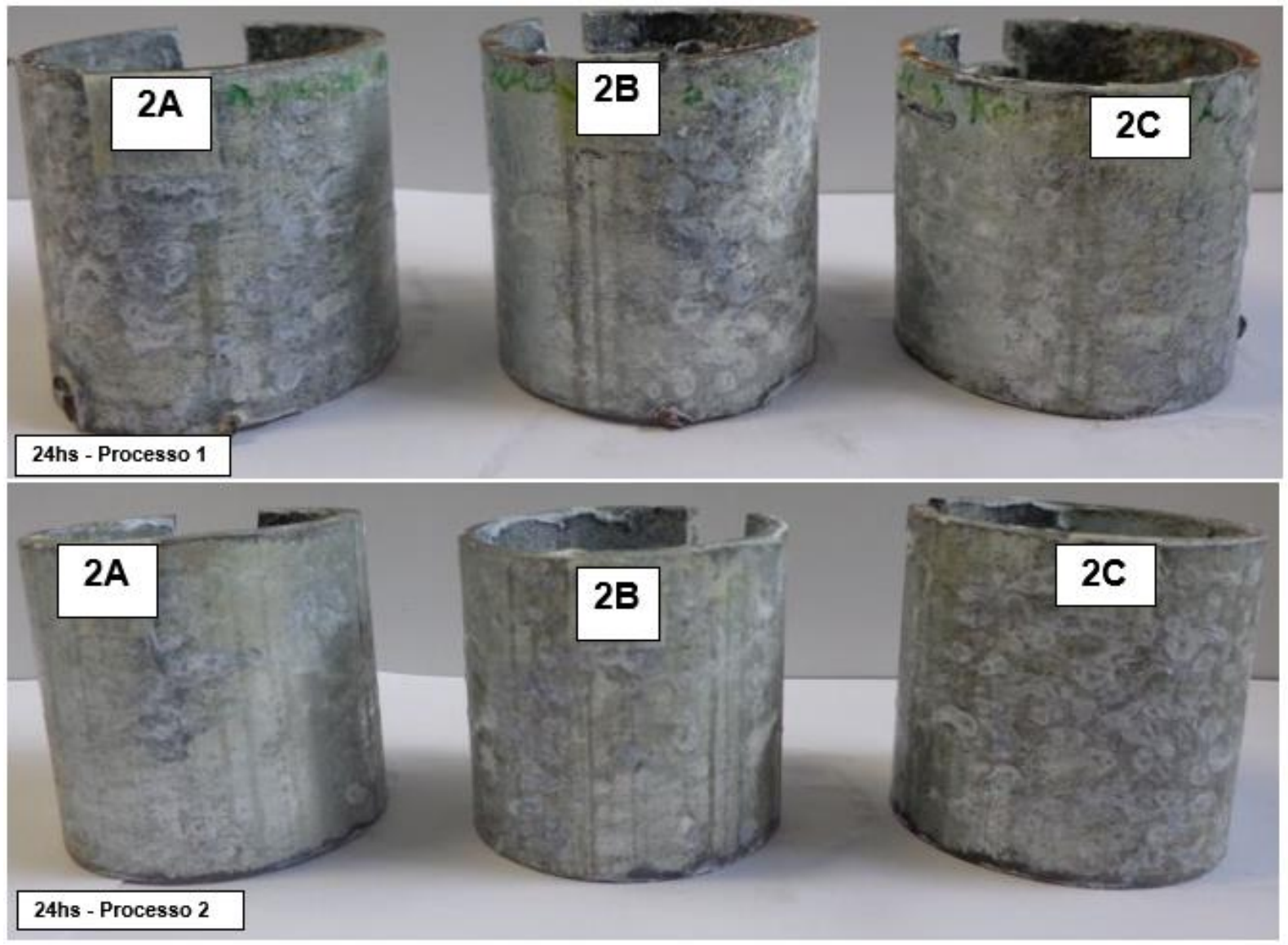

Figura 23 - 24 horas de ensaio em corpos de prova diâmetro 76,10mm - processo 1 e processo 2

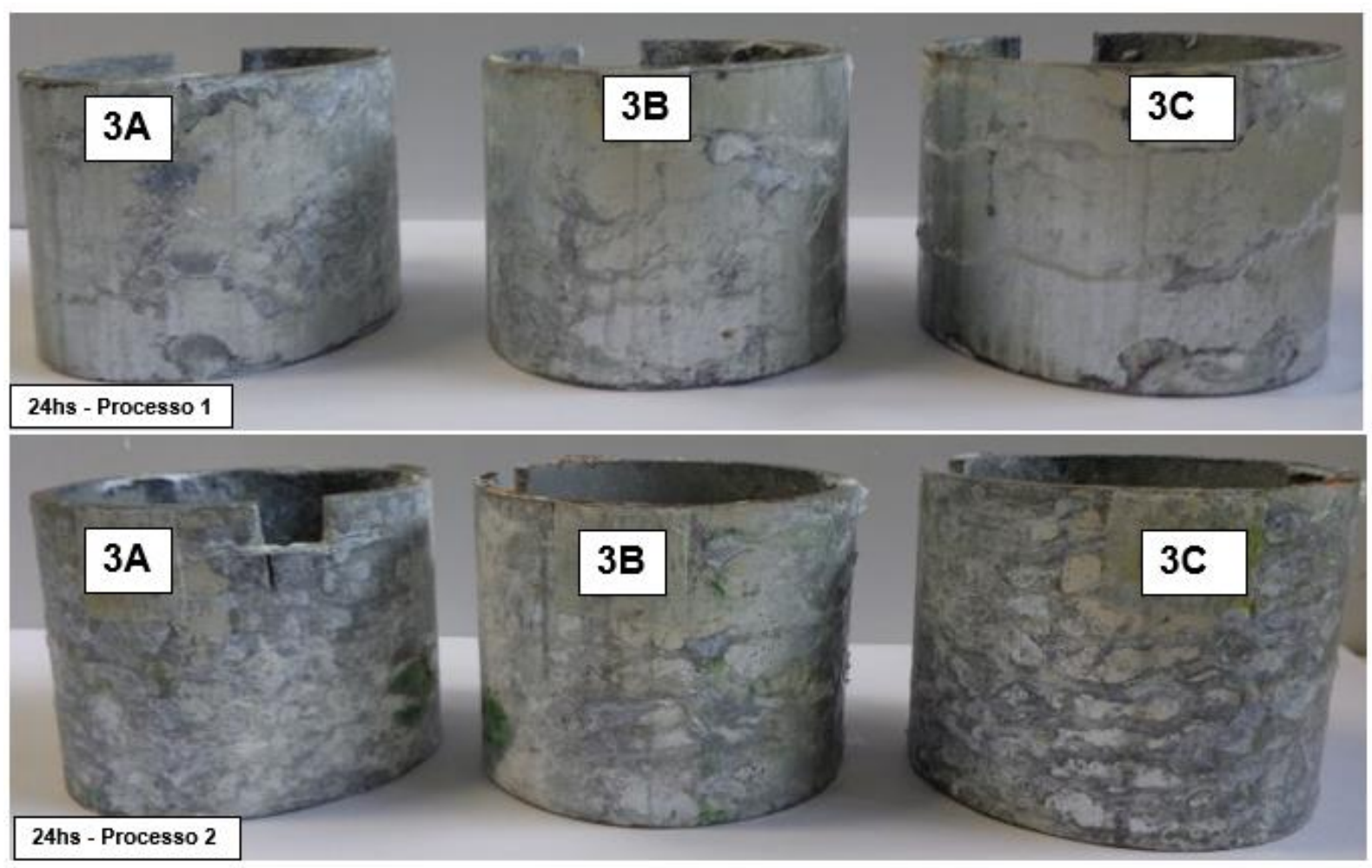


Nas Figuras 24 a 26 a seguir, é possível observar a evolução da corrosão nos corpos de provas submetidas a 336 horas de ensaio em névoa salina.

Figura 24 - 336 horas de ensaio em corpos de prova diâmetro 21,30mm - processo 1 e processo 2

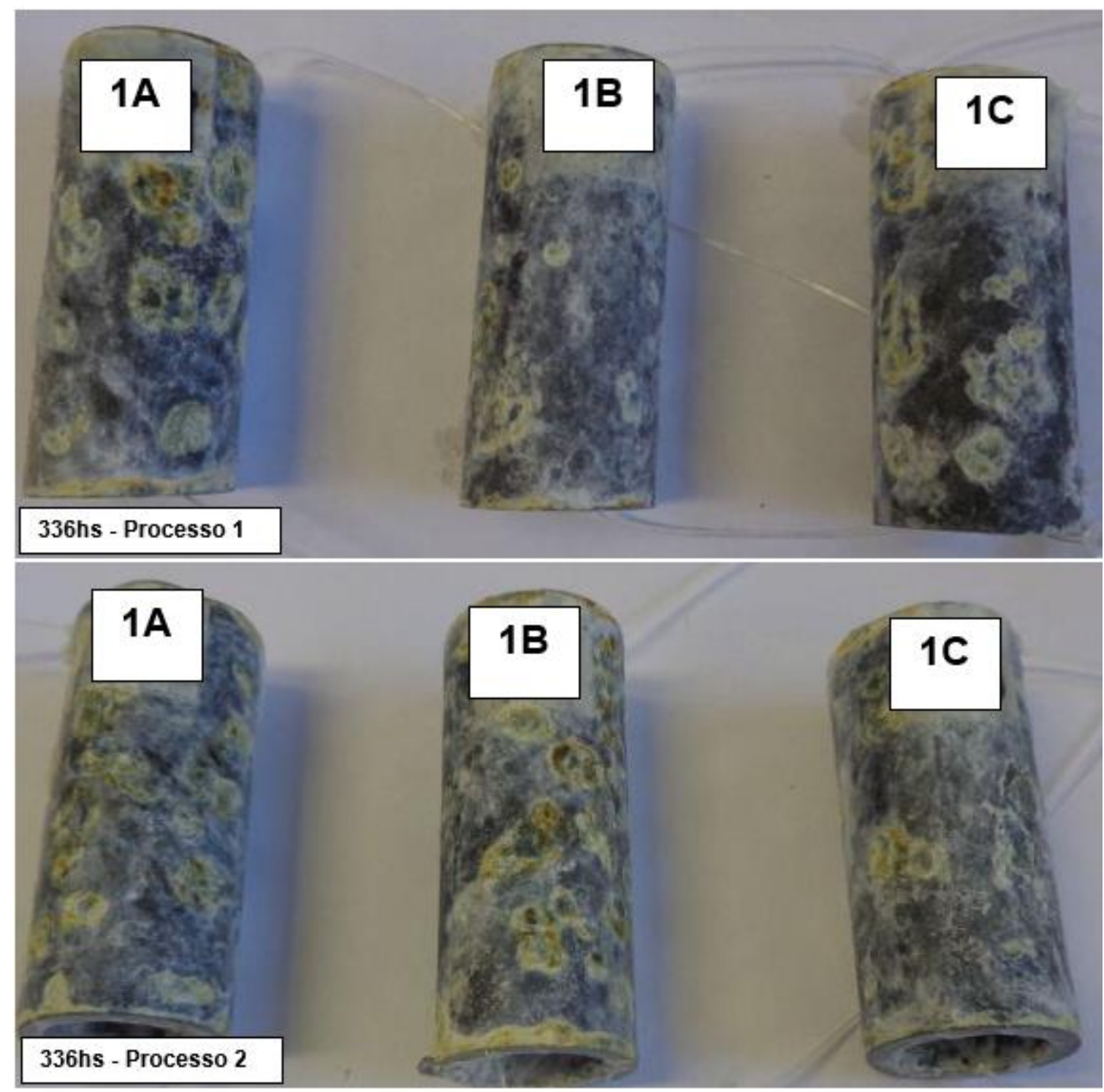


Figura 25 - 336 horas de ensaio em corpos de prova diâmetro 60,30mm - processo 1 e processo 2

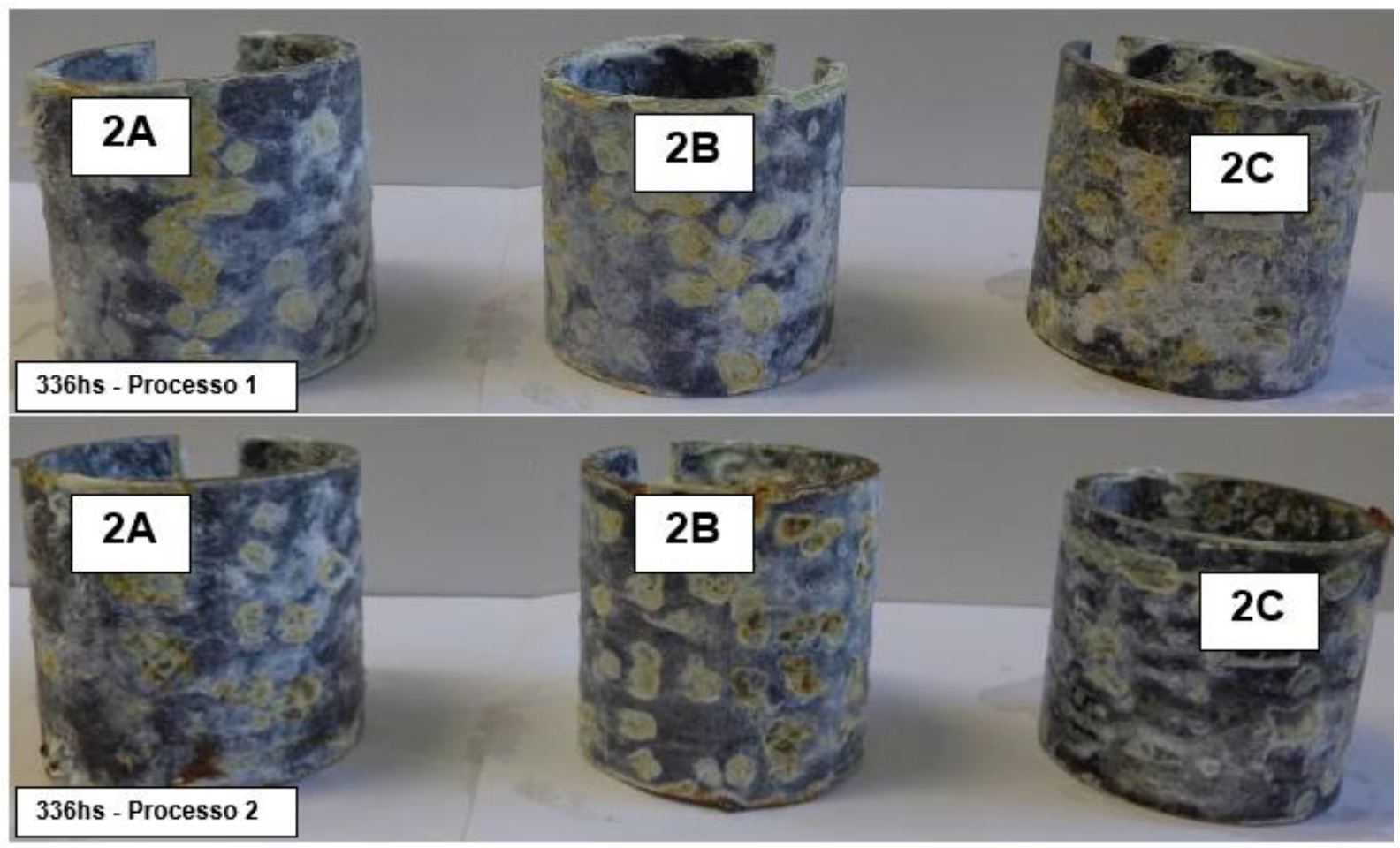

Figura 26 - 336 horas de ensaio em corpos de prova diâmetro 76,10mm - processo 1 e processo 2

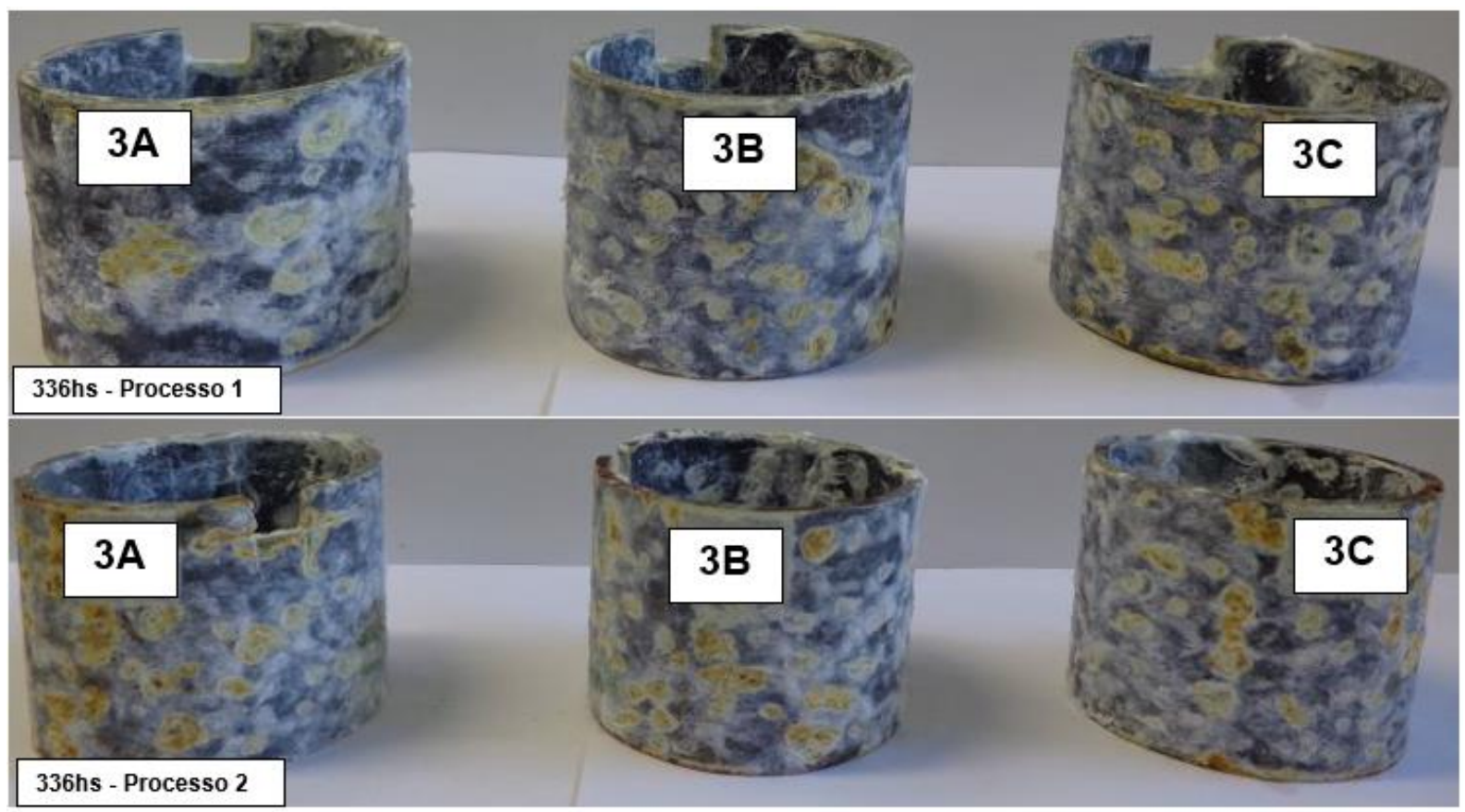

Nas Figuras 27 a 29 a seguir, é possível observar a evolução da corrosão nos corpos de provas submetidas a 1932 horas de ensaio em névoa salina. 
Figura 27 - 1392 horas de ensaio em corpos de prova diâmetro 21,30mm - processo 1 e processo 2
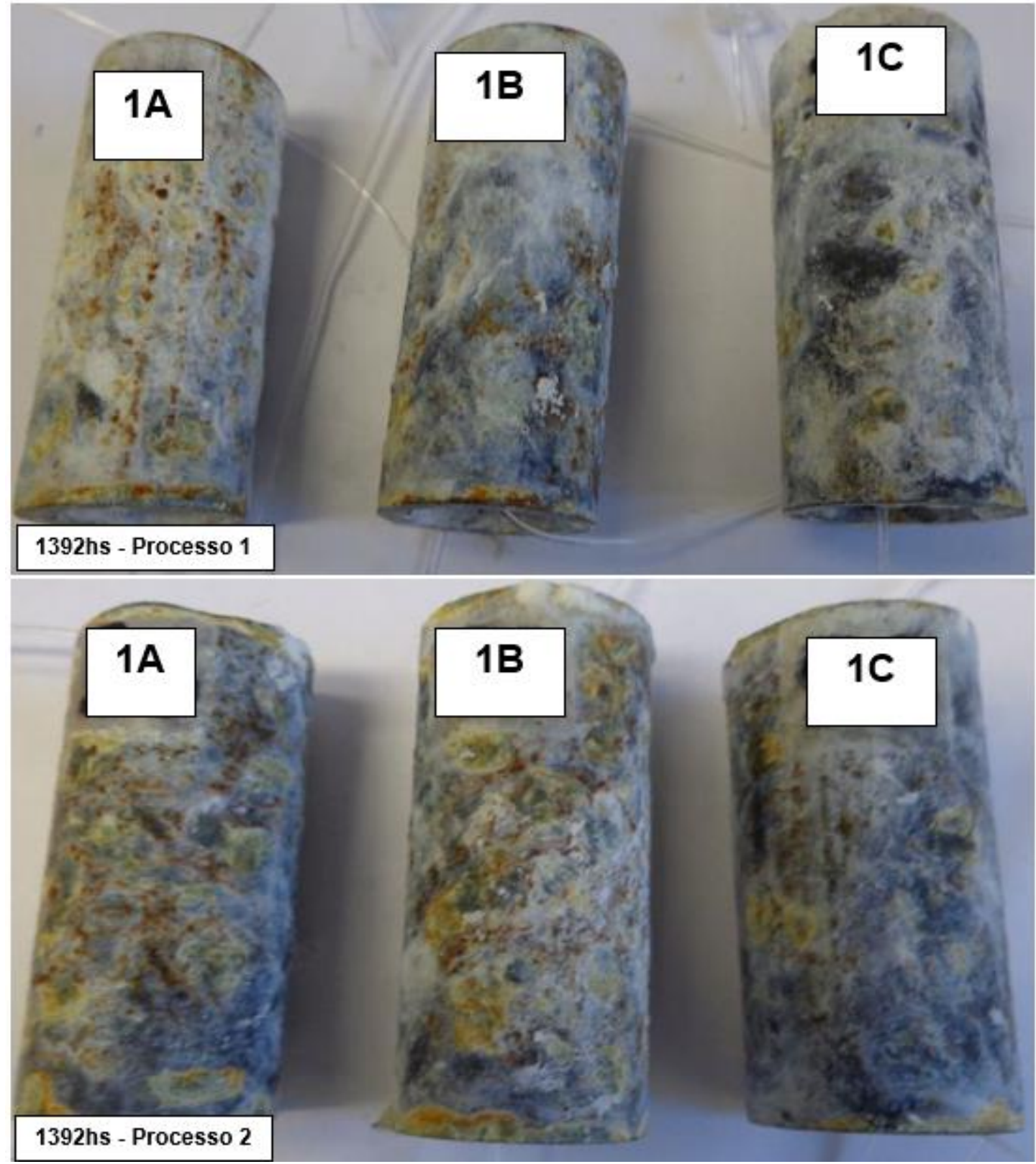
Figura 28 - 1392 horas de ensaio em corpos de prova diâmetro 60,30mm - processo 1 e processo 2

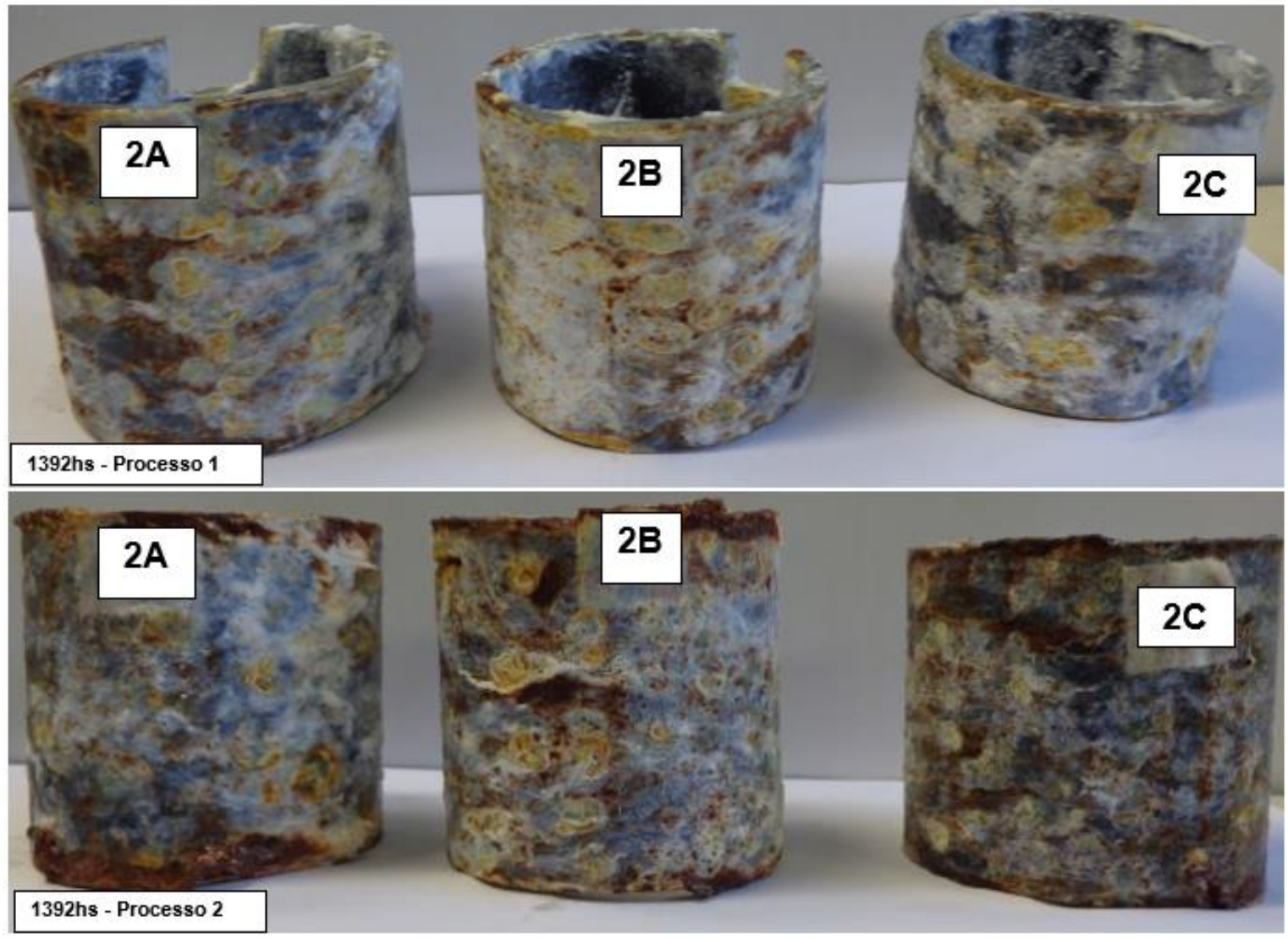

Figura 29 - 1392 horas de ensaio em corpos de prova diâmetro 76,10mm - processo 1 e processo 2

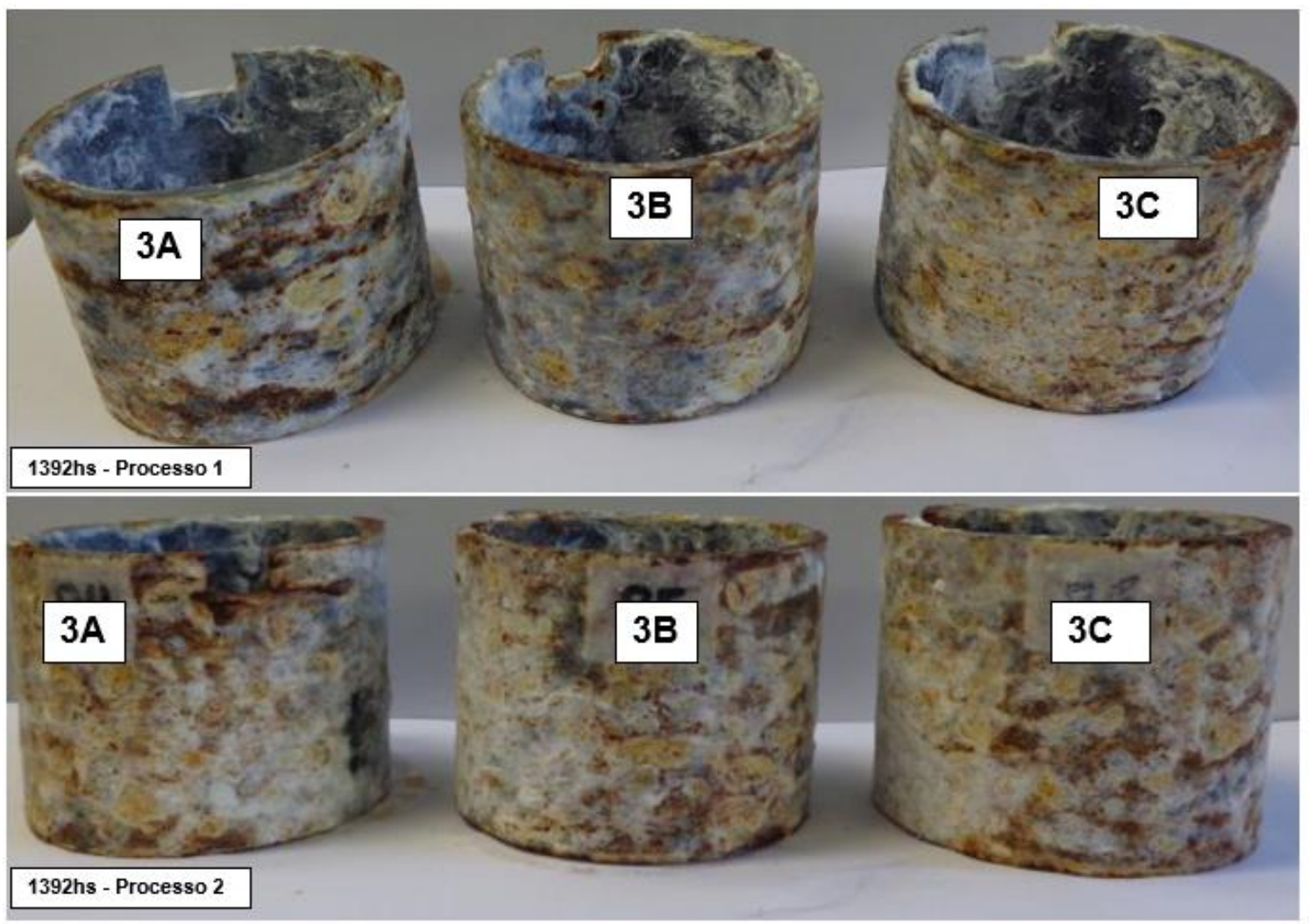


Observando as imagens e os resultados do ensaio de nevoa salina é possível observar que os corpos de prova de ambos os processos, em 24 horas atingiram o estágio de corrosão branca, variando de grau B3 a grau B4, sendo que todas as amostras do processo 2 atingiram grau B4 em corrosão branca. Em 192 horas de ensaio, todos os corpos de prova atingiram o grau máximo em corrosão branca, grau B5. Em 336 horas de ensaio foi possível observar os primeiros sinais de corrosão vermelha, sendo que apenas os corpos de prova 1B e 1C do processo 1 atingiram 0 grau V1 de corrosão vermelha e todos os demais corpos de prova do processo 1 e do processo 2 atingiram grau V3. Em 744 horas de ensaio, os corpos de prova 1A, $1 \mathrm{~B}$ e $1 \mathrm{C}$ do processo 2 evoluíram para grau V4; 3A, 3B e 3C do processo 1 e do processo 2 evoluíram para grau V5. Os corpos de prova 1A, 1B, 1C, 2A, 2B, e 2C do processo 1 alcançaram o grau V4 de corrosão vermelha em 1176 horas de ensaio, neste mesmo tempo, os corpos de prova $2 \mathrm{~A}, 2 \mathrm{~B}$, e $2 \mathrm{C}$ do processo 2 atingiram o grau $\mathrm{V} 5$. Ao final do ensaio, em 1392 horas, quase todos os corpos de prova haviam atingido o grau máximo de corrosão vermelha, $\mathrm{V} 5$, exceto os corpos de prova $1 \mathrm{~B}$ e $1 \mathrm{C}$ do processo 1 e $1 \mathrm{~A}$ e $1 \mathrm{~B}$ do processo 2 que se mantiveram no grau V4.

Analisando os resultados, de maneira geral, é possível perceber que os corpos de prova do processo 1 apresentaram maior resistência aos sinais de corrosão branca e vermelha no ensaio de névoa salina. Tal fato pode ser explicado pela maior espessura de camada de revestimento encontrada nos corpos de prova do processo 1. Porém, isto não significa que sejam peças com mais qualidade, uma vez que, há uma norma para tubos de condução galvanizados e ambos os processos apresentaram resultados em espessura de camada acima da espessura mínima de revestimento da referida norma.

\section{CONCLUSÕES}

Diante dos resultados dos ensaios de espessura, uniformidade e verificação de aderência do revestimento em ensaio de achatamento, foi possível concluir que em ambos processos os corpos de prova foram aprovados nos parâmetros analisados. Porém, os corpos de prova analisados referentes ao processo 2 apresentaram maior controle de espessura do revestimento de zinco, pois o desvio padrão das medidas diminuiu de 10,3 para $3,3 \mu \mathrm{m}$ e de 91,76 para $24,50 \mathrm{~g} / \mathrm{m}^{2}$. 
As imagens do ensaio de metalografia e MEV/EDS permitiram observar o crescimento das camadas de fase intermetálicas do revestimento e perceber que os corpos de prova do processo 2 obtiveram um crescimento de camadas de fases intermetálicas mais regular em relação ao processo 1 . Os resultados das análises da composição de $\mathrm{Fe}$ e $\mathrm{Zn}$ em EDS permitiram caracterizar as fases intermetálicas do revestimento.

O ensaio de névoa salina teve duração total de 1392 horas, sendo que em 24 horas apareceram os primeiros sinais de corrosão branca e em 336 horas de ensaio os primeiros sinais de corrosão vermelha. Conforme evidenciado nos ensaios de espessura de camada de revestimento, a inexistência de controle assertivo do tempo de imersão no processo 1 proporcionou maior espessura de revestimento às amostras deste processo. Devido a essa maior espessura de revestimento nos corpos de prova do processo 1, estas amostras apresentaram uma resistência um pouco superior à evolução dos sinais de corrosão branca e corrosão vermelha. Isto não necessariamente significa que as peças do processo 1 sejam de maior qualidade do que as peças do processo 2, visto que ambos os processos foram aprovados nos ensaios realizados. Manter a espessura da camada de revestimento mais próxima do mínimo exigido pela norma de referência torna o processo produtivo mais competitivo, aumentando a produtividade (menor consumo de zinco), camada de revestimento mais fina e homogênea.

De um modo geral é possível dizer que após as melhorias realizadas no processo, os controles estão mais eficientes, mantendo a qualidade do revestimento e contribuindo para redução de custos. 


\section{SUGESTÕES PARA TRABALHOS FUTUROS}

Avaliar as fases intermetálicas levando em consideração a presença de outros elementos no banho de zinco;

Avaliar a geração de resíduos de borra de zinco formados no processo e propor formas de controlar e/ou minimizar a geração destes resíduos e também as alternativas de valorização e reaproveitamento destes resíduos.

Avaliação do revestimento de zinco por Ensaios eletroquímicos (Polarização, Impedância, OCP). 


\section{REFERÊNCIAS BIBLIOGRÁFICAS}

1 GENTIL, V. Corrosão. Rio de Janeiro: GB. Almeida Neves; 1970.

2 CALLISTER, Jr. WD. Ciência e engenharia de materiais: uma Introdução. 5o edição. Rio de Janeiro: LTC; 2002.

3 CENTRO DE PESQUISAS EM ENERGIA ELÉTRICA - CEPEL. Galvanização: sua aplicação em equipamento elétrico. Rio de Janeiro: Ao Livro Técnico; 1979.

4 FRAUCHES,SC; ALBUQUERQUE, MA; OLIVEIRA, MCC; ECHEVARRIA A. A corrosão e os agentes anticorrosivos. Rev. Virtual Quim., 2014, 6 (2), 293-309. Data de publicação na Web: 20 de dezembro de 2013. ISSN 1984-6835

5 PANNONI, F. D. Princípios da Galvanização a Fogo. Centro Brasileiro da Construção em aço. São Paulo. 2008. Disponível em: < http://www.cbcaacobrasil.org.br/artigos-tecnicosler.php?cod=2935\&bsc $=>$ Acesso em: 15 de Julho de 2019.

6 ICZ INSTITUTO DE METAIS NÃO FERROSOS. Guia de galvanização por imersão a quente. Disponível em: <http://www.icz.org.br/biblioteca-digitalpublicacoes.php > Acesso em 05 de maio de 2019.

7 TOMACHUK, C.R.; COSTA, I. Revestimentos de zinco sobre aços e suas aplicações. Revista Corrosão \& Proteção, Edição 59, p. 26-33. Outubro 2015. Disponível em <http://www.icz.org.br/upfiles/fckeditor/file/2016-01revestimentos-de-zinco.pdf> Acesso em 05 de maio de 2019.

8 Catálogo de produtos Soluções Usiminas. Disponível em <http://www.usiminas.com/solucoes/wp-content/uploads/sites/5/2015/02/sucatalogo-online-j/an-2015.pdf > Acessso em 09 de março de 2019.

9 ABNT NBR 5580. Tubos de aço carbono para usos na condução de fluidos Especificação. Outubro, 2015.

10 NUNES, L. P. Fundamentos de Resistência à Corrosão. Editora Interciência, IBP ABRACO, 2007.

11 PANONI, F.D. Parafusos estruturais de aço ASTMA325 tipo 3 na construção em aço. Revista Construção Metálica, Edição111, p. 28-33. ISSN 1414-6517. 2013. 
12 Agência Sistema FIEP. Efeitos da corrosão afetam o PIB de um país, mas podem ser controlados. Março, 2019. Disponível em: $<$ https://agenciafiep.com.br/2019/03/18/efeitos-da-corrosao-afetam-o-pib-de-umpais/\#: : :text=Inova\%C3\%A7\%C3\%A3oEfeitos\%20da\%20corros\%C3\%A30\%20afetam\%200\%20PIB,pa\%C3\%ADs\%2 C\%20mas\%20podem\%20ser\%20controlados\&text=Um\%20estudo\%20de\%202 015\%20da,de\%20200\%20bilh\%C3\%B5es\%20de\%20reais.> Acesso em 15 de fevereiro de 2020.

13 SILVA, C.; FALDINI, S. Galvanização a quente: Processo por Batelada. Trabalho científico - Departamento de Engenharia de Materiais - Universidade Presbiteriana Mackenzie - São Paulo, 2014.

14 SANTOS, A.P.; RODRIGUES J.S.; DICK, L.F.P. Estudo comparativo da resistência à corrosão de aços revestidos pelos processos de galvanização a fogo, galvannealing e galvalume. Tecnologia em Metalurgia, Materiais e Mineração, vol. 10, n3, p. 280-286. ISSN 2176-1523. 2013.

15 ICZ INSTITUO DE METAIS NÃO FERROSOS. Revestimento para proteção: Corrosão branca e passivação no aço galvanizado por imersão a quente. Revista do Aço, Edição 7, 2013 Disponível em <http://www.icz.org.br/noticiasdetalhes. php?cod=4212>. Acesso em 09 de março de 2019.

16 ICZ INSTITUTO DE METAIS NÃO FERROSOS. Fluxograma de um processo de galvanização a fogo. Disponível em: <http://www.icz.org.br/fluxograma-de-umprocesso-de-galvanizacao-a-fogo.php >. Acesso em 05 de maio de 2019.

17 CAMPANHER, C.G. Otimização experimental em processo de galvanização de arames de camada pesada. Dissertação [Mestrado em Engenharia] Universidade Federal do Rio Grande do Sul. Porto Alegre, 2009.

18 SANTOS, S.G.; BARBOSA, A.H.A. Influência do teor de alumínio no banho de zinco na qualidade superficial de revestimentos galvannealed. In: $51^{\circ}$ Seminário de Laminação - Processos e Produtos Laminados e Revestidos - Internacional, p. 3324-3332. Foz do Iguaçu - Brasil, 2014.. ISSN: 2594-5297.

19 AMERICAN GALVANIZERS ASSOCIATION. Hot-Dip galvanizing for corrosion protection: a specifier's guide. 2012.

20 SHIBLI, S.M.A.; MEENA, B.N.; REMYA, R. A review on recent approaches in the field of hot dip zinc galvanizing. Surface and Coatings Technology. Vol. 262, p. 210-215. Janeiro, 2015.

21 MARDER, A.R. The metallurgy of zinc-coated steel. Progress in Materials Science, Vol. 45, p. 191-271. 2000. 
22 BEN NASR, J.; SNOUSSI, A.; BRADAI, C.; HALOUANI, F. Optimization of hotdip galvanizing process of reactive steels: Minimizing zinc consumption without alloy additions. Materials Letters; Volume 62, Issue 19, p. 3328-3330. July, 2008.

23 XIE, Y.; DU, A.; ZHAO, X.; MA, R.; FAN, Y.; CAO, X. Effect of Mg on Fe-Al interface structure of hot-dip galvanized $\mathrm{Zn}-\mathrm{Al}-\mathrm{Mg}$ alloy coatings. Surface \& Coatings Technology, Volume 337, p. 313-320. March, 2018.

24 HSU, C.W; KUANG-KUO, W.; CHANGA, L.; GAN, D.; CHANG, Y.L; LIANG, H.Y.; WANG, H.P.; Formation of Fe2Al5-xZnx intermetallic crystals at the Fe-Zn interface in hot-dip galvanizing. Materials Characterization, Volume 137, p.189200. March, 2018.

25 TUBONASA Tubos de aço carbono. Descubra a diferença entre tubos de aço com e sem costura. Setembro 2015. Disponível em: $<$ https://tubonasa.com.br/noticias/descubra-diferenca-entre-tubo-de-aco-com-esem-costura>. Acesso em 18 de junho de 2020.

26 CARVALHO, F. S.G. Extrusão a quente de tubos: Análise experimental da distribuição de tensões residuais na parede do tubo. Dissertação [Mestrado em Engenharia] - Universidade Federal de São João Del-Rei. São João Del Rei, 2013.

27 ABNT NBR 6323 - Galvanização por imersão a quente de produtos de aço e ferro fundido - Especificação. Julho, 2016.

28 ABNT NBR 7399 - Produto de aço e ferro fundido galvanizado por imersão a quente - Verificação da espessura do revestimento por processo não destrutivo Método de ensaio. Novembro, 2015.

29 ABNT NBR 7397 - Produto de aço ou ferro fundido revestido de zinco por imersão a quente - Determinação da massa do revestimento por unidade de área - Método de ensaio. Maio, 2007.

30 ABNT NBR 7400 - Galvanização de produtos de aço e ferro fundido por imersão a quente - Verificação da uniformidade do revestimento - Método de ensaio. Nov 2015.

31 ABNT NBR 6154 - Tubos de aço de seção circular - Ensaio de achatamento. Junho, 2015.

32 ABNT NBR 8094 - Material metálico revestido e não revestido - Corrosão por exposição à névoa salina - Método de ensaio. Julho, 1983. 
33 LME - London Metal Exchange. Preço oficiais do zinco da LME em U\$ por tonelada. Disponível em: <https://www.Ime.com/en-GB/Metals/Nonferrous/Zinc\#tabIndex=0) $>$. Acesso em 24/06/2021. 